\title{
Over the LEC rainbow: colour and stability tuning of cyclometallated iridium(III) complexes in light-emitting electrochemical cells
}

\author{
Catherine E. Housecroft* and Edwin C. Constable \\ Department of Chemistry, University of Basel, Spitalstrasse 51, 4056 Basel, \\ Switzerland
}

Email: catherine.housecroft@unibas.ch

\begin{abstract}
This review surveys the design of cyclometallated iridium(III) complexes for applications in light-emitting electrochemical cells (LECs). Typical iridiumcontaining ionic transition metal complexes (Ir-iTMCs) are of the general type $\left[\operatorname{Ir}\left(\mathrm{C}^{\wedge} \mathrm{N}\right)_{2}\left(\mathrm{~N}^{\wedge} \mathrm{N}\right)\right]^{+}$where $\mathrm{H}\left(\mathrm{C}^{\wedge} \mathrm{N}\right)$ is a cyclometallating ligand and $\mathrm{N}^{\wedge} \mathrm{N}$ is a $2,2^{\prime}-$ bipyridine (bpy), 1,10-phenanthroline (phen) or related, chelating ligand. In a more recently introduced series of emitters, the $\mathrm{N}^{\wedge} \mathrm{N}$ ligand has been replaced by a heterocyclic carbene. Since single component white-light emitting LECs are difficult to design, a more common approach is through colour-mixing. Colourtuning of $\left[\operatorname{Ir}\left(\mathrm{C}^{\wedge} \mathrm{N}\right)_{2}\left(\mathrm{~N}^{\wedge} \mathrm{N}\right)\right]^{+}$emissions is achieved by manipulation of the $\mathrm{C}^{\wedge} \mathrm{N}$ and/or $\mathrm{N}^{\wedge} \mathrm{N}$ units because the HOMO and LUMO are, respectively, localized on the $\operatorname{Ir} / \mathrm{C}^{\wedge} \mathrm{N}$ or $\mathrm{N}^{\wedge} \mathrm{N}$ domains. This review surveys synthetic strategies to Ir-iTMCs and illustrates the way in which ligand design can address emission colour and LEC stability. We consider the different approaches used to obtain blue-emitters; highly efficient and stable deep-blue emitters are required to complement the wide variety of orange emitting Ir-iTMCs for application in white-light devices. We also review the ways in which deep-red-emitting Ir-iTMCs are accessed. In
\end{abstract}


addition to targeting changes in the Ir-iTMC band-gap and therefore the colour of the emission, ligand-design is critical to improving LEC stability and turn-on times; only a handful of stable deep-red-emitting LECs have been reported. One successful strategy for improving device lifetime is the introduction of intracation $\pi$-stacking interactions which protect the iridium metal centre in the excited state of the complex; however, a wide range of investigations suggests that the choice of stacked rings is significant and that the involvement of the cyclometallated ring(s) may be important. There are now many data to confirm that the presence of peripheral bulky substituents is beneficial, resulting in greater spatial separation of the Ir-iTMC cations in the solid state which, in turn, reduces self-quenching. Finally, we comment on why it is often difficult to legitimately compare results of different investigations of LEC performances.

Keywords: Light-emitting electrochemical cell; iridium; ligand functionalization; ligand modification; device stability; device turn-on time

Abbreviations: Ir-iTMC = iridium ionic transition metal complex; $\mathrm{C}^{\wedge} \mathrm{N}=$ cyclometallating ligand; $\mathrm{N}^{\wedge} \mathrm{N}=$ chelating $N, N^{\prime}$-donor ligand; $\mathrm{HOMO}=$ highest occupied molecular orbital; LUMO = lowest unoccupied molecular orbital; DFT = density functional theory; TD-DFT = time dependent density functional theory; ITO = indium tin oxide; PEDOT:PSS = poly(3,4-ethylenedioxythiophene)poly(styrenesulfonate); PL = photoluminescence; EL = electroluminescence; $\mathrm{QY}$ = quantum yield; $\mathrm{EQE}=$ external quantum efficiency; $L_{\max }=$ maximum luminance; $t_{\mathrm{on}}=$ LEC turn-on time (see Section 1$) ; t_{1 / 2}=$ LEC lifetime; IL = ionic liquid; $[\mathrm{BMIM}]\left[\mathrm{PF}_{6}\right]$ = 1-butyl-3-methylimidazolium hexafluoridophosphate; 
[EMIM] $\left[\mathrm{PF}_{6}\right]$ = 1-ethyl-3-methylimidazolium hexafluoridophosphate; [TBA] [OTf]

= tetrabutylammonium triflate. Ligand abbreviations are defined in the schemes.

Dedication: This review is dedicated to our friend and colleague, Pierre Braunstein and celebrates his contributions to organometallic and coordination chemistries.

\section{Contents}

1 Introduction

2 Synthesis of $\left[\operatorname{Ir}\left(\mathrm{C}^{\wedge} \mathrm{N}\right)_{2}\left(\mathrm{~N}^{\wedge} \mathrm{N}\right)\right]^{+}$and $\left[\operatorname{Ir}\left(\mathrm{C}^{\wedge} \mathrm{N}\right)_{2}\left(\mathrm{~N}^{\wedge} \mathrm{C}_{\text {carbene }}\right)\right]^{+}$complexes

3 Archetype $\left[\operatorname{Ir}(\text { ppy })_{2}(\text { bpy })\right]^{+}$and $\left[\operatorname{Ir}(\text { ppy })_{2}(\text { phen })\right]^{+}$complexes

4 Intramolecular $\pi$-stacking in $\left[\operatorname{Ir}\left(\mathrm{C}^{\wedge} \mathrm{N}\right)_{2}\left(\mathrm{~N}^{\wedge} \mathrm{N}\right)\right]^{+}$complexes

5 Introduction of sterically-demanding substituents in the $\mathrm{N}^{\wedge} \mathrm{N}$ ligands

5.1 The effects of sterically-demanding substituents

5.2 Combining sterically-demanding substituents with intramolecular $\pi$-stacking

6 Blue-shifting the emission

6.1 Introducing fluoro-substituents into cyclometallating ligands

6.2 Fluorine-free blue emitters: use of other substituents

6.3 Cyclometallating ligands with nitrogen-rich heterocycles

6.4 $\quad \mathrm{N}^{\wedge} \mathrm{N}$ ligands with electron-donating substituents or nitrogen-rich heterocycles

6.5 $\quad N$-heterocyclic carbenes

7 Red-shifting the emission

8 Conclusions

Acknowledgements

References 


\section{$1 \quad$ Introduction}

Light-emitting electrochemical cells (LECs) differ from organic light-emitting diodes (OLEDs) in that the active material in a LEC is a charged (rather than neutral) species. Early LECs incorporated luminescent polymers containing ionic salts [1]. In 1996, the first LEC employing an ionic transition metal complex (iTMC) was reported [2]; it contained a $\left[\mathrm{Ru}(\mathrm{bpy})_{3}\right]^{2+}$-based compound $(\mathrm{bpy}=$ 2,2'-bipyridine) in the active layer. Development of Ru-iTMCs is impeded by the low stability of Ru-iTMC-containing devices under operating conditions and the difficulty of shifting the emission colour away from the orange-red region. A move from ruthenium to iridium is advantageous both in terms of device stability and emission-colour tuning. Most iridium(III) complexes for LECs are based upon a cyclometallated complex of the type $\left[\operatorname{Ir}\left(\mathrm{C}^{\wedge} \mathrm{N}\right)_{2}\left(\mathrm{~N}^{\wedge} \mathrm{N}\right)\right]^{+}$in which $\mathrm{H}\left(\mathrm{C}^{\wedge} \mathrm{N}\right)$ is a cyclometallating ligand and $\mathrm{N}^{\wedge} \mathrm{N}$ is a 2,2'-bipyridine, 1,10phenanthroline (phen) or related, chelating ligand.

$[3,4,5,6,7,8,9,10,11,12,13,14,15]$. More recently introduced electroluminophores include those with $N$-heterocyclic carbenes replacing the $\mathrm{N}^{\wedge} \mathrm{N}$ ligand (see Section $6.5)$.

The layered architecture of a LEC (Fig. 1) is simpler than that of an OLED, although Duan and coworkers have demonstrated the successful use of cationic cyclometallated iridium(III) complexes as electroluminophores in OLEDs comprising a simple architecture [16]. After application of an electrical bias across a LEC, the ions in the active layer migrate towards the anode or cathode. The ions accumulate at the electrode interfaces forming doped zones. Widening of these $\mathrm{p}$ - and n-doped zones leads to the formation of a $\mathrm{p}-\mathrm{i}-\mathrm{n}$ junction $\mathrm{i}=$ intrinsic or non-doped region) and emission of light through the transparent ITO 
layer (Fig. 1) occurs in the intrinsic region when electrons and holes recombine [17]. In contrast to OLEDs, it is not a requirement for LECs to employ a low workfunction metal as cathode because the barrier charge injection is reduced by the formation of an electric double layer. Air-stable electrodes such as Al can be used, resulting in the advantageous application of solution (rather than vacuum) processing. Figure 1 shows a schematic representation of a double-layer LEC with a hole injection layer of poly(3,4-ethylenedioxythiophene)poly(styrenesulfonate) (PEDOT:PSS). This layer is not included in the simplest device architectures. The active material in the LEC is an Ir-iTMC and the archetype compound is $\left[\operatorname{Ir}(\text { ppy })_{2}(\text { bpy })\right]^{+}($Hppy = 2-phenylpyridine) (Fig. 1). The structure in Fig. 1 shows that the nitrogen donors of the two cyclometallating ligands are mutually trans, and this arrangement is the norm in $\left[\operatorname{Ir}\left(\mathrm{C}^{\wedge} \mathrm{N}\right)_{2}\left(\mathrm{~N}^{\wedge} \mathrm{N}\right)\right]^{+}$ complexes. Note also that, being an octahedral tris-chelate, an $\left[\operatorname{Ir}\left(\mathrm{C}^{\wedge} \mathrm{N}\right)_{2}\left(\mathrm{~N}^{\wedge} \mathrm{N}\right)\right]^{+}$ cation is chiral, a point to which we return in Section 5.1. A $\left[\mathrm{PF}_{6}\right]^{-}$counter-ion is a common choice, but the relatively large ion size leads to low ion mobility, resulting in slow LEC turn-on times $\left(t_{\mathrm{on}}\right)$. It is important to note that $t_{\mathrm{on}}$ is defined in different ways in different studies; it may be the time to reach maximum luminance or the time to reach a specified luminance. To overcome low ion mobility, the electroluminophore is usually blended with an ionic liquid (IL) $[18,19]$.

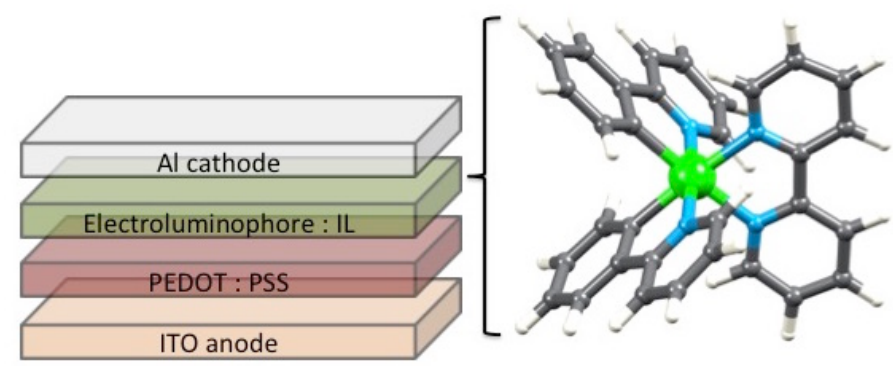


Fig. 1 Schematic representation of a LEC device and the structure of $\left[\operatorname{Ir}(\text { ppy })_{2}(\text { bpy })\right]^{+}$as an example of the electroluminophore in the active layer. The configuration of the device shown is represented as ITO/PEDOT:PSS/IriTMC:IL/Al.

Single-component white-light emitters are, of course, highly desirable, but are difficult to realize. In their absence, two-component white-light emitting LECs are a critical objective. An alternative strategy is to use a single Ir-iTMC that is a dual emitter. However, this approach has not, to date, been successful [20]. There is a wide range of orange Ir-iTMC emitters to choose from, but there remains a need for complementary deep-blue emitters. The paucity of highly efficient and stable deep-blue-emitting complexes required for colour-blending is the fundamental reason behind the small number and poor performances of white-light-emitting LECs. A huge advantage of $\left[\operatorname{Ir}\left(\mathrm{C}^{\wedge} \mathrm{N}\right)_{2}\left(\mathrm{~N}^{\wedge} \mathrm{N}\right)\right]^{+}$complexes is that colour-tuning of the emission can be accomplished by manipulation of the electronic properties of the $\mathrm{C}^{\wedge} \mathrm{N}$ and/or $\mathrm{N}^{\wedge} \mathrm{N}$ ligands. Since the highest-occupied molecular orbital (HOMO) and lowest-unoccupied molecular orbital (LUMO) are, respectively, localized on the $\operatorname{Ir} / \mathrm{C}^{\wedge} \mathrm{N}$ or $\mathrm{N}^{\wedge} \mathrm{N}$ domains (Fig. 2), the band gap can be altered through ligand functionalization. Although we shall not be concerned in this review with the detailed discussion of theoretical results, such studies for ground and excited states of iTMCs are fundamental to an understanding of experimental results and to the development of new ligands $[10,21,22,23,24,25,26]$. 

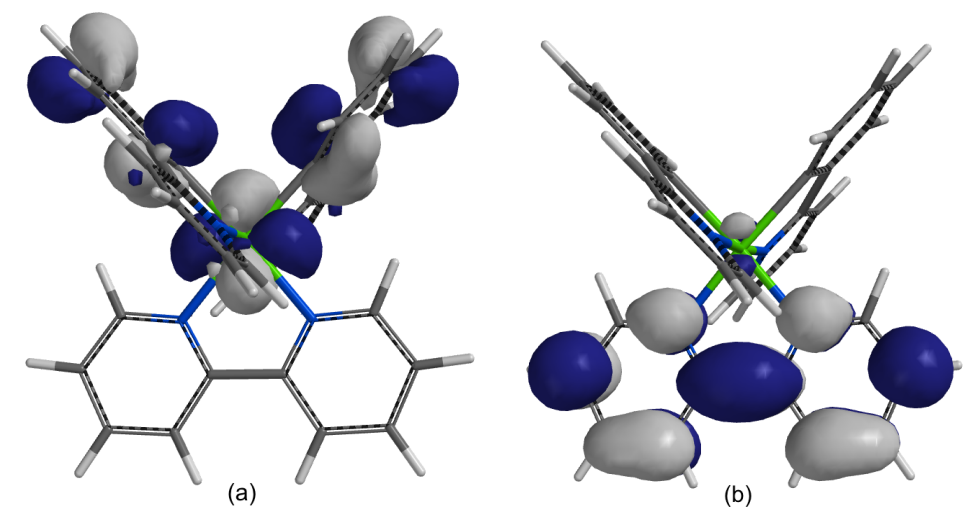

Fig. 2. Orbital character of (a) the HOMO (localized on the $\mathrm{N}^{\wedge} \mathrm{N}$ unit) and (b) the LUMO (localized on the $\left\{\left(\mathrm{C}^{\wedge} \mathrm{N}\right)_{2} \operatorname{Ir}\right\}$ unit) of the $\left[\operatorname{Ir}(\mathrm{ppy})_{2}(\mathrm{bpy})\right]^{+}$cation; calculated at DFT level (B3LYP, 6-31G*) using Spartan 16, Wavefunction Inc.

Although described in detail elsewhere [3], it is appropriate to comment on some general features of the photophysical properties of Ir-iTMCs. A typical absorption spectrum exhibits intense, high-energy bands arising from spinallowed ligand-centred transitions, most usually $\pi^{*} \leftarrow \pi$. At lower energy, metalto-ligand charge transfer ( $\left.{ }^{1} \mathrm{MLCT}\right)$ and ligand-to-ligand charge transfer ( $\left.{ }^{1} \mathrm{LLCT}\right)$ transitions give rise to a broad absorptions. The large spin-orbit coupling constant of iridium leads to mixing of singlet and triplet states, allowing access to otherwise spin-forbidden transitions. The emitting state of an Ir-iTMC is the lowest energy triplet state and may have contributions from ${ }^{3}$ MLCT, ligandcentred ( ${ }^{3}$ LC) and ${ }^{3}$ LLCT states. Broad emission bands indicate dominant chargetransfer character, whereas structured emission bands typify a large ${ }^{3} \mathrm{LC}$ character of the emissive state.

In this review, we describe how ligand design is used to alter the emission wavelength of the luminophore. We also discuss how the turn-on time of a LEC can be shortened and the LEC lifetime increased by altering the structural properties of the ligands. The lifetime, $t_{1 / 2}$, is defined as the time for the 
luminance (or brightness) to decay from its maximum value, $L_{\max }$ (or $B_{\max }$ ) to half this value, $L_{\max } / 2$ (or $B_{\max } / 2$ ). Two significant difficulties that emerge when surveying the LEC literature and comparing data are the variation in device architectures (e.g. with or without a hole-transport layer, with or without IL) and the device operating conditions.

Finally, a word about 'colour'. The most reliable description of the colour of light emitted by a LEC is by use of CIE colour space coordinates (CIE $=$ Commission internationale de l'éclairage or International commission on illumination). However, for an overview of the LEC field, it is unfortunate that there is not a common adoption of the CIE standard for all publications. We have therefore opted to focus on emission wavelengths and the colours of emissions that authors use in their original work. Since colour is a subjective visual description, this leads to some unavoidable inconsistencies.

\section{Synthesis of $\left[\operatorname{Ir}\left(C^{\wedge} N\right)_{2}\left(N^{\wedge} N\right)\right]^{+}$and $\left[\operatorname{Ir}\left(C^{\wedge} N\right)_{2}(N H C)\right]^{+}$complexes}

The synthesis of $\left[\operatorname{Ir}\left(\mathrm{C}^{\wedge} \mathrm{N}\right)_{2}\left(\mathrm{~N}^{\wedge} \mathrm{N}\right)\right]^{+}$cations usually involves the reaction of a chlorido-bridged $\left[\operatorname{Ir}_{2}\left(\mathrm{C}^{\wedge} \mathrm{N}\right)_{4} \mathrm{Cl}_{2}\right]$ dimer with the $\mathrm{N}^{\wedge} \mathrm{N}$ ancillary ligand. This is illustrated in Scheme 1 by the formation of $\left[\operatorname{Ir}(\mathrm{ppy})_{2}(\mathrm{bpy})\right]\left[\mathrm{PF}_{6}\right]$. The most widely employed method of preparing the dimeric $\left[\operatorname{Ir}_{2}\left(\mathrm{C}^{\wedge} N\right)_{4} \mathrm{Cl}_{2}\right]$ precursor is the reaction of $\operatorname{IrCl}_{3} \cdot x \mathrm{H}_{2} \mathrm{O}$ with the cyclometallating ligand $\mathrm{H}\left(\mathrm{C}^{\wedge} \mathrm{N}\right)$ (Scheme 1 ) [27]. However, in some cases, this route is not effective [28] and an alternative method is the reaction of the commercially available $\left[\operatorname{Ir}_{2}(\mathrm{COD})_{2} \mathrm{Cl}_{2}\right]$ with $\mathrm{H}\left(\mathrm{C}^{\wedge} \mathrm{N}\right)$ (COD = 1,5-cyclooctadiene, Scheme 1) [29]. This strategy has also been used to prepare mixtures of heteroleptic dimers such as $\left[\operatorname{Ir}_{2}(\text { ppy })_{4-n}(\mathrm{dfppy})_{n}(\mu-\mathrm{Cl})_{2}\right]$ (Hdfppy = 2-(2,4-difluorophenyl)pyridine) [30]. Hexafluoridophosphate salts 
$[\mathrm{X}]\left[\mathrm{PF}_{6}\right]$ are common choices for the final anion exchange step in Scheme 1, but $\left[\mathrm{BF}_{4}\right]^{-},\left[\mathrm{BPh}_{4}\right]^{-}$or $\left[\mathrm{BIm}_{4}\right]^{-}(\mathrm{HIm}=$ imidazole $)$ ions also form stable salts of the IriTMC cations [31,32].

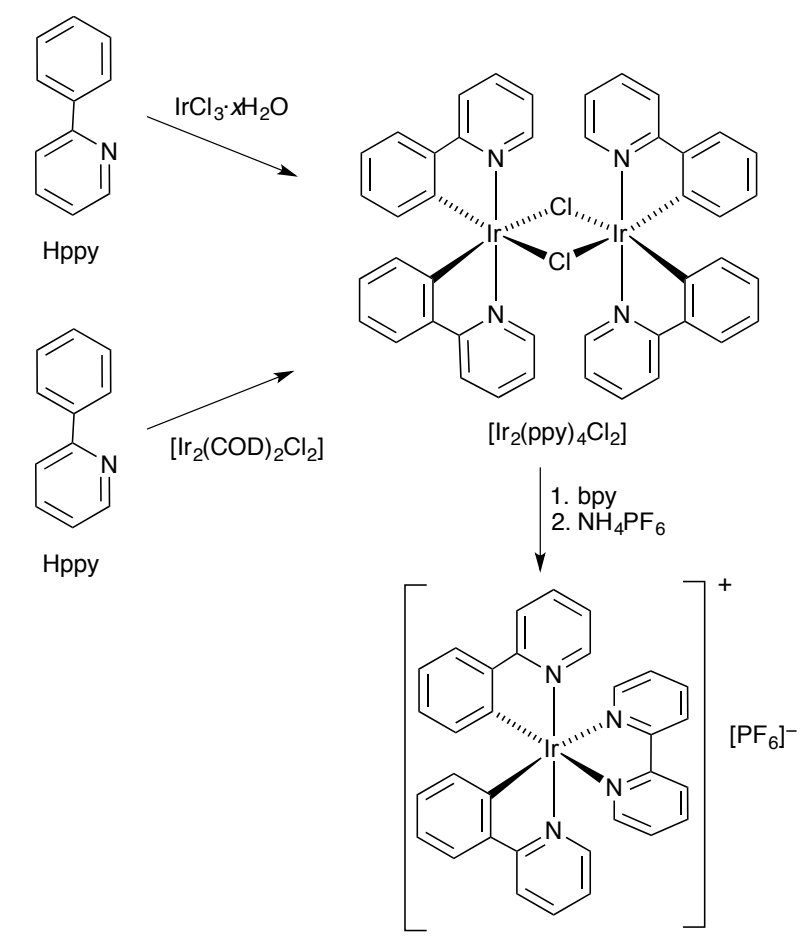

Scheme 1. Synthesis of $\left[\operatorname{Ir}(\mathrm{ppy})_{2}(\mathrm{bpy})\right]\left[\mathrm{PF}_{6}\right]$ via a chlorido-bridged dimer.

While most Ir-iTMCs contain two identical $\mathrm{C}^{\wedge} \mathrm{N}$ ligands, Dumur and coworkers have developed an elegant approach to the synthesis of $\left[\operatorname{Ir}\left(\mathrm{C}^{\wedge} \mathrm{N}\right)\left(\mathrm{C}^{\wedge} \mathrm{N}\right)^{\prime}\left(\mathrm{N}^{\wedge} \mathrm{N}\right)\right]^{+}$ species [33]. Initial reaction of $\operatorname{IrCl}_{3} \times \mathrm{H}_{2} \mathrm{O}$ with an equivalent of each of two different cyclometallating ligands, $H\left(C^{\wedge} N\right)$ and $H\left(C^{\wedge} N\right)^{\prime}$, leads to a statistical mixture of chlorido-bridged dimers $\left[\operatorname{Ir}_{2}\left(\mathrm{C}^{\wedge} \mathrm{N}\right)_{4-x}\left(\mathrm{C}^{\wedge} \mathrm{N}\right)^{\prime}{ }_{x} \mathrm{Cl}_{2}\right]$ with $x=0,1,2,3$ or 4; for $x=2$, the two identical ligands can be bound to the same or different Ir centres. The difficulty in separating this mixture of compounds is overcome by treatment with Hacac which leads to three neutral complexes $\left[\operatorname{Ir}\left(\mathrm{C}^{\wedge} \mathrm{N}\right)_{2}(\right.$ acac $\left.)\right]$, $\left[\operatorname{Ir}\left(\mathrm{C}^{\wedge} \mathrm{N}\right)\left(\mathrm{C}^{\wedge} \mathrm{N}\right)^{\prime}(\mathrm{acac})\right]$ and $\left[\operatorname{Ir}\left(\mathrm{C}^{\wedge} \mathrm{N}\right)_{2}{ }_{2}(\mathrm{acac})\right]$. After chromatographic separation, 
the mixed ligand compound is converted back to a chlorido-bridged dimer (Scheme 2) and is available for reaction with an $\mathrm{N}^{\wedge} \mathrm{N}$ ligand as in Scheme 1.

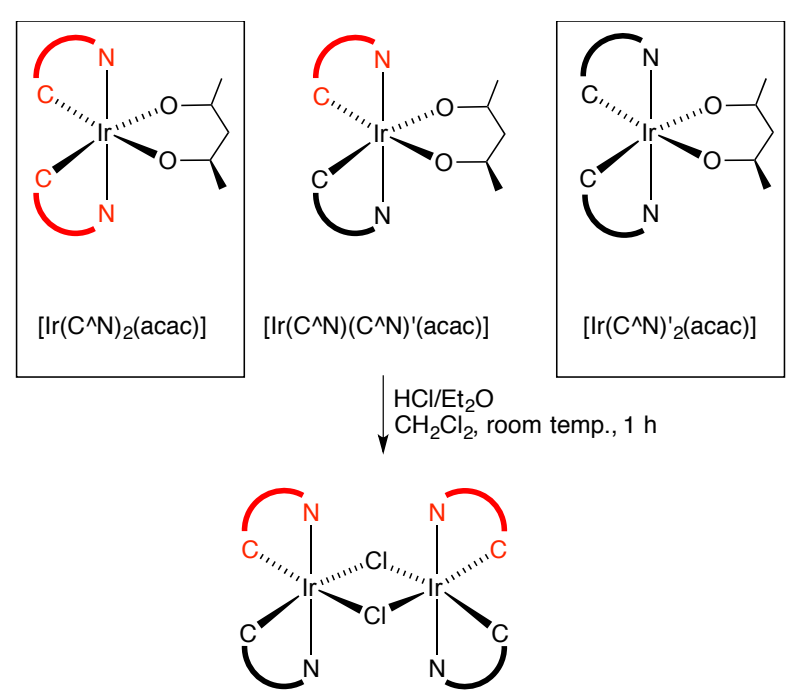

Scheme 2. Preparation of the mixed-ligand dimer $\left[\left\{\operatorname{Ir}\left(\mathrm{C}^{\wedge} \mathrm{N}\right)\left(\mathrm{C}^{\wedge} \mathrm{N}\right)^{\prime}\right\}_{2} \mathrm{Cl}_{2}\right]$ after separation of $\left[\operatorname{Ir}\left(\mathrm{C}^{\wedge} \mathrm{N}\right)\left(\mathrm{C}^{\wedge} \mathrm{N}\right)^{\prime}(\right.$ acac $\left.)\right]$ from a mixture of $\left[\operatorname{Ir}\left(\mathrm{C}^{\wedge} \mathrm{N}\right)_{2}(\right.$ acac $\left.)\right]$, $\left[\operatorname{Ir}\left(\mathrm{C}^{\wedge} \mathrm{N}\right)\left(\mathrm{C}^{\wedge} \mathrm{N}\right){ }^{\prime}(\right.$ acac $\left.)\right]$ and $\left[\operatorname{Ir}\left(\mathrm{C}^{\wedge} \mathrm{N}\right)^{\prime} 2(\right.$ acac $\left.)\right]$.

A problem that may be encountered with the general strategy shown in Scheme 1 is the presence of $\mathrm{Cl}^{-}$ion in the product. When incorporated into the active layer in a LEC, traces of chloride ion can impact significantly on LEC performance leading to lower luminances. In cases where tight ion-pairing between the bpy $\mathrm{H}^{3}$ protons and $\mathrm{Cl}^{-}$occurs (Fig. 3 ), $\mathrm{Cl}^{-}$ion may be carried through the synthesis [34]. To circumvent this problem, a solvento approach can be used. This is based on a strategy from Watts [35] in which a $\left[\operatorname{Ir}_{2}(\mathrm{ppy}){ }_{4} \mathrm{Cl}_{2}\right]$ dimer is treated with a soluble silver salt to abstract $\mathrm{Cl}^{-}$in the form of insoluble AgCl. Both $\mathrm{MeOH}[36,37]$ and MeCN [38] have been used as coordinating solvents and have led to Ir-iTMCs used in green and red light-emitting LECs which display exceptional stabilities [36,37]. 


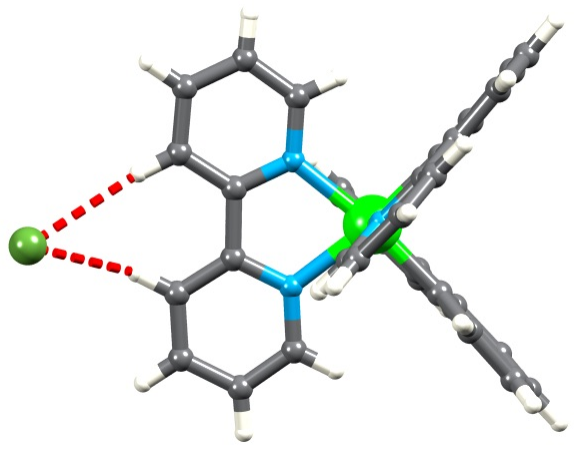

Fig. 3. Ion-pairing between $\left[\operatorname{Ir}(\mathrm{ppy})_{2}(\mathrm{bpy})\right]^{+}$and $\mathrm{Cl}^{-}$confirmed in the single crystal structure of $2\left\{\left[\operatorname{Ir}(\mathrm{ppy})_{2}(\mathrm{bpy})\right][\mathrm{Cl}]\right\} \cdot 2 \mathrm{CH}_{2} \mathrm{Cl}_{2} \cdot\left[\mathrm{H}_{3} \mathrm{O}\right][\mathrm{Cl}]$ (CSD refcode RISMOX [34]).

The replacement of the $\mathrm{N}^{\wedge} \mathrm{N}$ ligand in $\left[\operatorname{Ir}\left(\mathrm{C}^{\wedge} \mathrm{N}\right)_{2}\left(\mathrm{~N}^{\wedge} \mathrm{N}\right)\right]^{+}$by a chelate comprising $N$-heterocyclic carbene (NHC) donors was first reported for use in LECs by De Cola and coworkers [39]. A typical synthetic pathway is shown in Scheme 3.
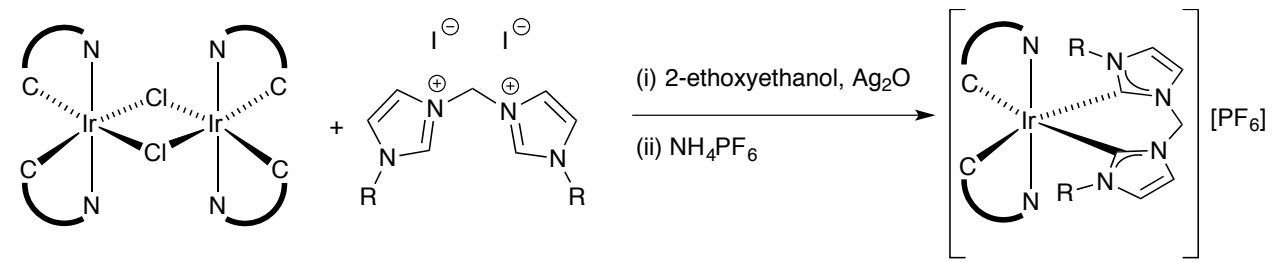

Scheme 3. A synthetic pathway to an $\left[\operatorname{Ir}\left(\mathrm{C}^{\wedge} \mathrm{N}\right)_{2}(\mathrm{NHC})\right]^{+}$complex.

\section{$3 \quad$ A benchmarking study: archetype $\left[\operatorname{Ir}(p p y)_{2}(\text { bpy })\right]^{+}$and}

\section{$\left[\operatorname{Ir}(p p y)_{2}(\text { phen })\right]^{+}$complexes}

The archetype $\operatorname{Ir}-i T M C s$ are $\left[\operatorname{Ir}(\text { ppy })_{2}(\text { bpy })\right]^{+}\left(\right.$Fig. 1) and $\left[\operatorname{Ir}(\text { ppy })_{2}(\text { phen })\right]^{+}($see Scheme 4 for phen). The photophysical properties of these complexes and their electroluminescence in LECs provide a benchmark from which ligand-design for emission colour-tuning can begin. $\left[\operatorname{Ir}(\mathrm{ppy})_{2}(\mathrm{bpy})\right]\left[\mathrm{PF}_{6}\right]$ is an orange-emitter, exhibiting room temperature photoluminescence (PL) with $\lambda_{\mathrm{em}}{ }^{\max }=585 \mathrm{~nm}$ in MeCN solution [40] (595 nm in $\mathrm{CH}_{2} \mathrm{Cl}_{2}$ [41]) and electroluminescence (EL) with $\lambda_{\mathrm{em}}{ }^{\max }=590 \mathrm{~nm}[40]$. A change from bpy to phen leads to a values of solution PL 
$\lambda_{\mathrm{em}}{ }^{\max }=530 \mathrm{~nm}$ and $\mathrm{EL} \lambda_{\mathrm{em}}{ }^{\max }=578 \mathrm{~nm}$. The broad, unstructured PL bands are typical for MLCT electronic transitions [3] (see Section 1). The PL quantum yields (PLQY) for deaerated MeCN solutions of $\left[\operatorname{Ir}(p p y)_{2}(b p y)\right]\left[\mathrm{PF}_{6}\right]$ and $\left[\operatorname{Ir}(\mathrm{ppy})_{2}(\mathrm{phen})\right]\left[\mathrm{PF}_{6}\right]$ are 14 and $17 \%$, respectively, and these values increase to 66 and 71\% for poly(methylmethacrylate) (PMMA) thin films of the complexes. An increase in PLQY on going from fluid solution to thin film is typical. The performances of LECs containing $\left[\operatorname{Ir}(\mathrm{ppy})_{2}(\mathrm{bpy})\right]\left[\mathrm{PF}_{6}\right]$ or $\left[\operatorname{Ir}(\mathrm{ppy})_{2}(\mathrm{phen})\right]\left[\mathrm{PF}_{6}\right]$ in the active layer are significantly affected by the use of ionic liquid (IL) as demonstrated by the data in Table 1 . A LEC with $\left[\operatorname{Ir}(\mathrm{ppy})_{2}(\mathrm{bpy})\right]\left[\mathrm{PF}_{6}\right]$ in the active layer outperforms that containing $\left[\operatorname{Ir}(\mathrm{ppy})_{2}(\mathrm{phen})\right]\left[\mathrm{PF}_{6}\right]$ (Table 1). Although an enhanced $L_{\max }$ is achieved by blending the complex with IL, the LEC lifetimes are significantly reduced [40]. Improved luminances, reduced values of $t_{\text {on }}$ and long device lifetimes have been found to result from the addition of $[\mathrm{X}]\left[\mathrm{PF}_{6}\right]\left(\mathrm{X}^{+}=\mathrm{NH}_{4}^{+}, \mathrm{K}^{+}\right.$or $\left.\mathrm{Li}^{+}\right)$to $\left[\operatorname{Ir}(\mathrm{ppy})_{2}(\mathrm{bpy})\right]\left[\mathrm{PF}_{6}\right]$ in a LEC [42] and, similarly, the use of an $\mathrm{Li}\left[\mathrm{PF}_{6}\right]$ additive improves the performance of LECs with $[\operatorname{Ir}(2,4-$ $\left.\left.\mathrm{Ph}_{2} \mathrm{py}\right)_{2}(\mathrm{bpy})\right]\left[\mathrm{PF}_{6}\right]\left(2,4-\mathrm{Ph}_{2} \mathrm{py}\right.$, see Scheme 4) in the active layer [43].

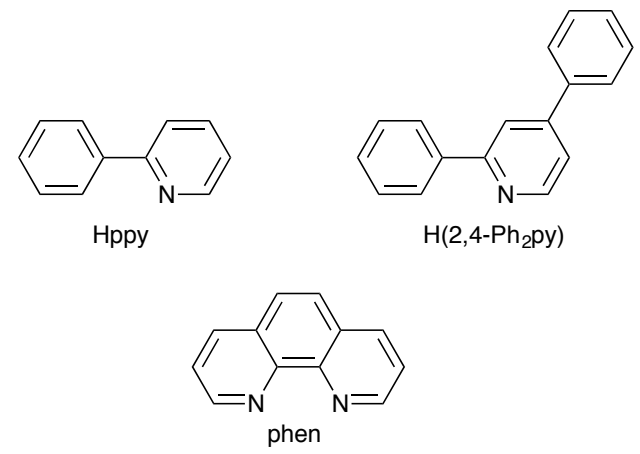

Scheme 4. Structures of cyclometallating ligands 2-phenylpyridine (Hppy) and 2,4-diphenylpyridine, and the $\mathrm{N}^{\wedge} \mathrm{N}$ ligand 1,10-phenanthroline. 


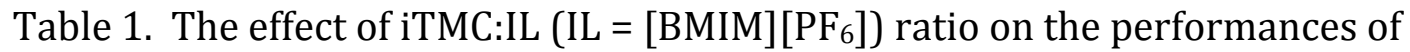
LECs with $\left[\operatorname{Ir}(\text { ppy })_{2}(\right.$ bpy $\left.)\right]\left[\mathrm{PF}_{6}\right]$ or $\left[\operatorname{Ir}(\text { ppy })_{2}(\right.$ phen $\left.)\right]\left[\mathrm{PF}_{6}\right]$ in the active layer. LEC configuration was ITO/PEDOT:PSS/Ir-iTMC:[BMIM][PF6]/Al [40].

\begin{tabular}{lccll}
\hline $\begin{array}{l}\text { Ratio Ir-iTMC }: \\
{[\text { BMIM }]\left[\mathrm{PF}_{6}\right]}\end{array}$ & $t_{\text {on }} / \mathrm{h}^{\mathrm{a}}$ & $L_{\max } / \mathrm{cd} \mathrm{m}^{-2}$ & $t_{1 / 2} / \mathrm{h}^{\mathrm{b}}$ & $\mathrm{EQE}^{\mathrm{c}}$ \\
\hline $1: 0$ & 70.2 & {$\left[\operatorname{Ir}(\mathrm{ppy})_{2}(\mathrm{bpy})\right]\left[\mathrm{PF}_{6}\right]$} & \\
$4: 1$ & 7.2 & 334 & 668 & 2.1 \\
$1: 1$ & 0.7 & 375 & 69 & 3.0 \\
& & {$\left[\operatorname{Ir}(\mathrm{ppy})_{2}(\mathrm{phen})\right]\left[\mathrm{PF}_{6}\right]$} & 5.6 \\
$1: 0$ & 160 & 40 & 567 & 1.5 \\
$4: 1$ & 6.4 & 63 & 73 & 2.1 \\
$1: 1$ & 0.09 & 101 & 0.33 & 3.3 \\
\hline
\end{tabular}

${ }^{a} t_{\text {on }}=$ time to reach maximum luminance under a constant bias of $3 \mathrm{~V}\left(L_{\max }\right)$.

b $t_{1 / 2}=$ time from voltage-turn-on to the time to decay to half the maximum luminance $\left(L_{\max } / 2\right)$.

\section{$4 \quad$ Intramolecular $\pi$-stacking in $\left[\operatorname{Ir}\left(C^{\wedge} N\right)_{2}\left(N^{\wedge} N\right)\right]^{+}$complexes}

Before continuing with a discussion of colour-tuning of emissions of Ir-iTMCs, we describe the use of face-to-face $\pi$-stacking interactions [44] within the iridium(III) coordination sphere to stabilize the electroluminophore in both the ground and excited states. Each of the six donor atoms in a typical $\left[\operatorname{Ir}\left(\mathrm{C}^{\wedge} \mathrm{N}\right)_{2}\left(\mathrm{~N}^{\wedge} \mathrm{N}\right)\right]^{+}$complex is part of an aromatic ring and, therefore, if $\mathrm{N}^{\wedge} \mathrm{N}$ is bpy or phen, aryl substituents in the 6,6'-positions of bpy or 2,9-positions of phen can orient themselves to engage in a face-to-face $\pi$-stacking interaction with a cyclometallated ring of an adjacent ligand. The implications of such interactions were first demonstrated in 2008 when we revealed that LECs containing [Ir(ppy)2(ptbpy) $]^{+}$(see Fig. 4 for ptbpy) were especially long-lived [45]. The presence of a $\pi$-stacking interaction was established crystallographically for the ground state complex (Fig. 4) and DFT calculations showed that the interaction persists in the excited state. The stacking contacts limit expansion along the N-Ir-N vector in the excited state and, in turn, this 
minimizes the risk of attack by $\mathrm{H}_{2} \mathrm{O}$ which results in occupancy of an $\mathrm{MO}$ with antibonding character between the N-Ir-N atoms. For a LEC with configuration ITO/PEDOT:PSS/Ir-iTMC:[BMIM][PF 6$](0.26$ wt.\% IL)/Al and

$\left[\operatorname{Ir}(\mathrm{ppy})_{2}(\mathrm{ptbpy})\right]\left[\mathrm{PF}_{6}\right]$ in the active layer, the time to reach $L_{\max }\left(626 \mathrm{~cd} \mathrm{~m}^{-2}\right)$ was $6 \mathrm{~h}$ with the device under a constant bias of $3 \mathrm{~V}$. The device lifetime was $25 \mathrm{~h}$. A reduction in the amount of $[\mathrm{BMIM}]\left[\mathrm{PF}_{6}\right]$ to $0.13 \mathrm{wt} . \%$ led to a longer $t_{\mathrm{on}}(136 \mathrm{~h}$ to reach $L_{\max }=230 \mathrm{~cd} \mathrm{~m}^{-2}$ ) but a significantly longer device lifetime (estimate $\sim 680$ h) confirming remarkable LEC stability associated with the intramolecular $\pi$ stacking.

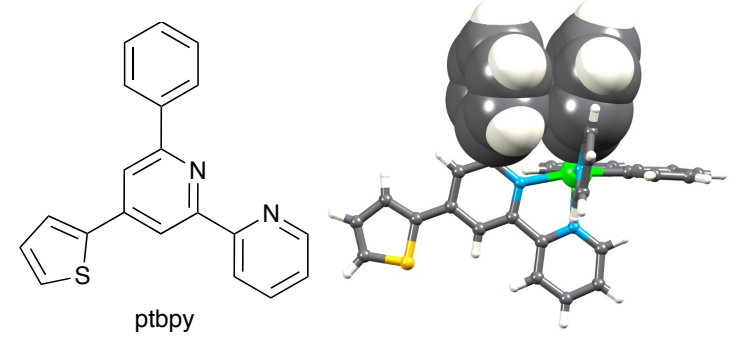

Fig. 4. The structure of the $\mathrm{N}^{\wedge} \mathrm{N}$ ligand ptbpy, and the face-to-face $\pi$-stacking interaction within the $\left[\operatorname{Ir}(\text { ppy) })_{2}(\text { ptbpy) }]^{+}\right.$cation (CSD refcode NOLXES [45]).

The advantages of $\pi$-stacking are seen in a comparison of the performances of LECs containing $\left[\operatorname{Ir}(\mathrm{ppy})_{2}(\mathrm{bpy})\right]\left[\mathrm{PF}_{6}\right]$ or $\left[\operatorname{Ir}(\mathrm{ppy})_{2}(\mathrm{Phbpy})\right]\left[\mathrm{PF}_{6}\right]$ (Fig. 5a) in the active layer [46]. The solution emission maximum of $\left[\operatorname{Ir}(\mathrm{ppy})_{2}(\mathrm{Phbpy})\right]\left[\mathrm{PF}_{6}\right]$ (595 nm, orange emission) is the same as that of $\left[\operatorname{Ir}(\mathrm{ppy})_{2}(\mathrm{bpy})\right]\left[\mathrm{PF}_{6}\right]$. To optimize the performance of a LEC in configuration ITO/PEDOT:PSS/[Ir(ppy) $2(\mathrm{Phbpy}]\left[\mathrm{PF}_{6}\right] / \mathrm{Al}, \mathrm{IL}$ was added to the active layer and the device was driven with a pulsed high-voltage bias. Under a bias of $7 \mathrm{~V}, L_{\max }$ was $2200 \mathrm{~cd} \mathrm{~m}^{-2}$ and $t_{\text {on }}$ was $1 \mathrm{~min}$. The LEC was then driven under a $3 \mathrm{~V}$ bias and exhibited an exceptional lifetime exceeding $3000 \mathrm{~h}$, about 100 times longer than a similarly configured LEC with $\left[\operatorname{Ir}(\mathrm{ppy})_{2}(\mathrm{bpy})\right]\left[\mathrm{PF}_{6}\right]$ as the 
electroluminophore. An analogous stabilizing effect is observed on going from $\left[\operatorname{Ir}(\mathrm{ppy})_{2}(\mathrm{phen})\right]\left[\mathrm{PF}_{6}\right]$ to $\left[\operatorname{Ir}(\mathrm{ppy})_{2}(\mathrm{Phphen})\right]\left[\mathrm{PF}_{6}\right]$ (Fig. 5b) [47]. Further improvement on device stability might be thought to accompany the introduction of a second $\pi$-stacking interaction within the iridium coordination sphere, but this seems not to be the case. Even though a LEC with $\left[\operatorname{Ir}(\mathrm{ppy})_{2}\left(\mathrm{Ph}_{2} \mathrm{bpy}\right)\right]\left[\mathrm{PF}_{6}\right]\left(\mathrm{Ph}_{2}\right.$ bpy, see Fig. 5) in the active layer is indeed longlived $\left(t_{1 / 2} \sim 1300 \mathrm{~h}\right)$ [48], the value of $t_{1 / 2}$ does not exceed that of a LEC in which the electroluminophore is $\left[\operatorname{Ir}(\mathrm{ppy})_{2}(\mathrm{Phbpy})\right]\left[\mathrm{PF}_{6}\right]$. Replacing the 6-phenyl by a 6(2-naphthyl) domain (Fig. 6) has little effect on the solution photoluminescence $\left(\lambda_{\mathrm{em}}{ }^{\mathrm{max}}=598 \mathrm{~nm}\right.$ for $\left[\operatorname{Ir}(\mathrm{ppy})_{2}(\mathrm{Naphbpy})\right]\left[\mathrm{PF}_{6}\right]$ compared to $\lambda_{\mathrm{em}}{ }^{\max }=595 \mathrm{~nm}$ for $\left.\left[\operatorname{Ir}(\mathrm{ppy})_{2}(\mathrm{Phbpy})\right]\left[\mathrm{PF}_{6}\right]\right)$ and leads to bright and stable LECs. This has been demonstrated using a LEC in configuration

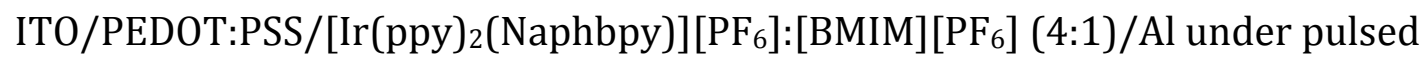
driving mode. The LEC had characteristics of $L_{\max }>300 \mathrm{~cd} \mathrm{~m}^{-2}$ with no loss in brightness over a period of $350 \mathrm{~h} \mathrm{[49].}$
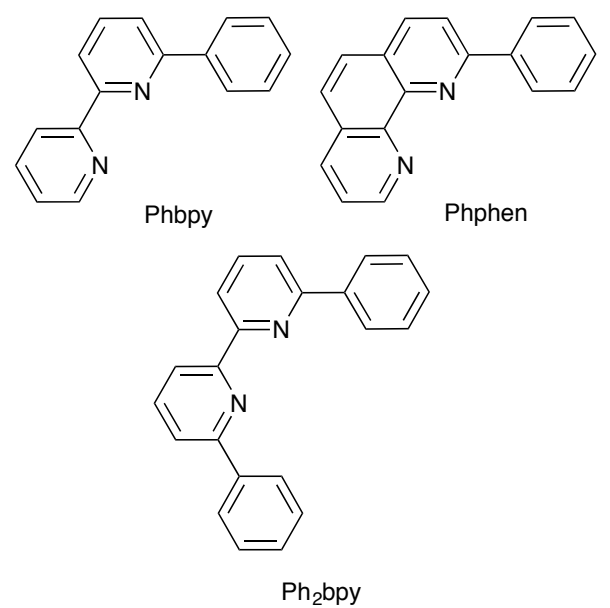

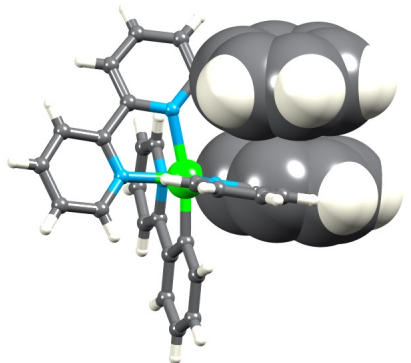

(a)

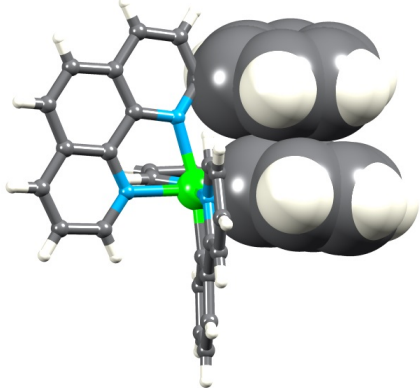

(b)

Fig. 5. The structures of Phbpy, Phphen and $\mathrm{Ph}_{2} \mathrm{bpy}$, and the crystallographically determined structures of the cations in (a) $\left[\operatorname{Ir}(\mathrm{ppy})_{2}(\mathrm{Phbpy})\right]\left[\mathrm{PF}_{6}\right][46]$ and (b) [Ir(ppy) $\left.{ }_{2}(\mathrm{Phphen})\right]\left[\mathrm{PF}_{6}\right] \cdot 2 \mathrm{H}_{2} \mathrm{O}$ (CSD refcode UXUYIW) [47]. 

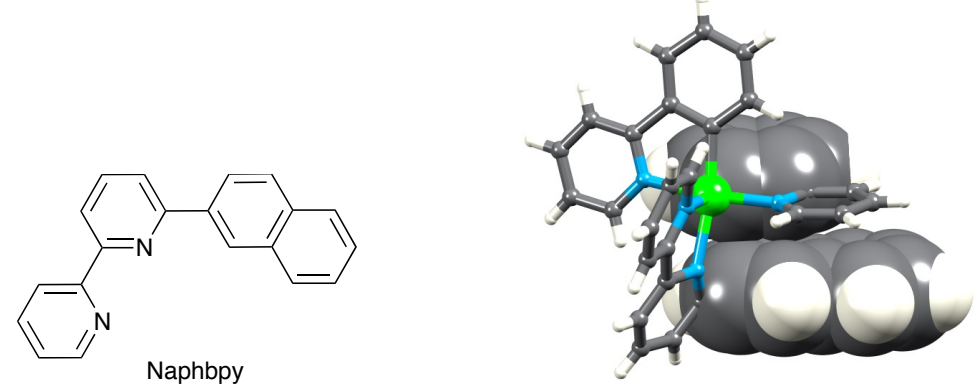

Fig. 6. The structure of Naphbpy and the crystallographically determined structure of the cation in [Ir(ppy) $\left.{ }_{2}(\mathrm{Naphbpy})\right]\left[\mathrm{PF}_{6}\right]$ (CSD refcode LOHZEP) [49].

Aryl-substituted cyclometallated ligands also lead to intramolecular $\pi-$ stacking interactions, and because an Ir-iTMC usually contains two identical $\mathrm{C}^{\wedge} \mathrm{N}$ ligands, multiple $\pi$-stacks can be introduced. By judicious selection of the substitution sites, beneficial effects can be engineered by functionalization of the cyclometallating ligands, but as the following results show, involvement of the cyclometallated ring(s) appears to be critical. Li et al. designed a doubly stacked motif by using a 2,6-diphenylpyridine domain in the ligands $\mathrm{H}\left(2,6-\mathrm{Ph}_{2} \mathrm{py}\right)$ and $\mathrm{H}\left(2,4,6-\mathrm{Ph}_{3} \mathrm{Ph}\right)$ (Fig. 7). The double $\pi$-stack was confirmed in the single crystal structure of $\left[\operatorname{Ir}\left(2,4,6-\mathrm{Ph}_{3} \mathrm{py}\right)_{2}(\right.$ phen $\left.)\right]\left[\mathrm{PF}_{6}\right] \cdot 4 \mathrm{H}_{2} \mathrm{O}$ (Fig. 7); note that, in this case, the $\pi$-contacts do not involve the cyclometallated rings. In solution, $[\operatorname{Ir}(2,6-$ $\left.\left.\mathrm{Ph}_{2} \mathrm{py}\right)_{2}(\mathrm{phen})\right]\left[\mathrm{PF}_{6}\right]$ and $\left[\operatorname{Ir}\left(2,4,6-\mathrm{Ph}_{3} \mathrm{py}\right)_{2}(\right.$ phen $\left.)\right]\left[\mathrm{PF}_{6}\right]$ are green emitters $\left(\lambda_{\mathrm{em}}{ }^{\max }=552\right.$ and $\left.546 \mathrm{~nm}\right)$. However, LECs in configuration ITO/PEDOT:PSS/IriTMC:[BMIM] $\left[\mathrm{PF}_{6}\right](4: 1) / \mathrm{Al}$ driven under a bias of $3 \mathrm{~V}$ or $8 \mathrm{~V}$ with $[\operatorname{Ir}(2,6-$ $\mathrm{Ph}_{2}$ py) ${ }_{2}($ phen $\left.)\right]\left[\mathrm{PF}_{6}\right]$ or $\left[\operatorname{Ir}\left(2,4,6-\mathrm{Ph}_{3} \mathrm{py}\right)_{2}(\right.$ phen $\left.)\right]\left[\mathrm{PF}_{6}\right]$ in the emissive layer did not turn on. Inspection of the crystal structure reveals that the presence of the double $\pi$-stack causes significant distortion of the coordination environment in the ground state. Supporting DFT/TD-DFT calculations for the excited state complex indicate that the double $\pi$-stack is not effective in preventing the 
coordination sphere from opening up [50]. The positions of the two phenyl substituents in 2-(3,5-diphenyl)phenylpyridine (H(Ph 2 ppy), Fig. 8) lead to two independent $\pi$-stacking motifs in $\left[\operatorname{Ir}\left(\mathrm{Ph}_{2} \mathrm{ppy}\right)_{2}(\mathrm{bpy})\right]^{+}$(Fig. 8a). Both stacking interactions are between a pyridine ring of the $\mathrm{C}^{\wedge} \mathrm{N}$ ligand and a pendant phenyl ring. In $\mathrm{CH}_{2} \mathrm{Cl}_{2}$ solution, $\left[\operatorname{Ir}\left(\mathrm{Ph}_{2} \text { ppy }\right)_{2}(\mathrm{bpy})\right]\left[\mathrm{PF}_{6}\right]$ has an emission maximum at $611 \mathrm{~nm}$ which shifts to $600 \mathrm{~nm}$ for a powder sample. A LEC with $\left[\operatorname{Ir}\left(\mathrm{Ph}_{2} \mathrm{ppy}\right)_{2}(\mathrm{bpy})\right]\left[\mathrm{PF}_{6}\right]$ and the IL $[\mathrm{BMIM}]\left[\mathrm{PF}_{6}\right](4: 1)$ in the active layer (operated with a pulsed current driving mode) attained $L_{\max }=425 \mathrm{~cd} \mathrm{~m}^{-2}$ with $t_{\mathrm{on}}=1.21 \mathrm{~h}$. The LEC showed good stability with $t_{1 / 2}=360 \mathrm{~h}$. However, the role of the $\pi$-stacking is difficult to assess since a LEC containing the related $\left[\operatorname{Ir}(\mathrm{Phppy})_{2}(\mathrm{bpy})\right]\left[\mathrm{PF}_{6}\right]$ which exhibits no intra-cation $\pi$-stacking (Fig. 8b) has a higher luminance $\left(L_{\max }=1024 \mathrm{~cd} \mathrm{~m}^{-2}\right)$ and longer lifetime $\left(t_{1 / 2}=2800 \mathrm{~h}\right)$ [36]. We further developed this series of electroluminophores to include pendant phenyl substituents on both the $\mathrm{C}^{\wedge} \mathrm{N}$ and $\mathrm{N}^{\wedge} \mathrm{N}$ domains and achieved exceptional device stability for a LEC with $\left[\operatorname{Ir}\left(\mathrm{Ph}_{2} \mathrm{ppy}\right)_{2}(\mathrm{Phbpy})\right]\left[\mathrm{PF}_{6}\right]$ in the active layer; the LEC configuration was ITO/PEDOT:PSS/Ir-iTMC:[BMIM][PF 6$]$ (4 : 1)/Al. The time to reach $L_{\max }\left(261 \mathrm{~cd} \mathrm{~m}^{-2}\right)$ was only $0.05 \mathrm{~h}$ and the lifetime exceeded $2800 \mathrm{~h}$ [36]. Structural characterization of $\left[\operatorname{Ir}\left(\mathrm{Ph}_{2} \mathrm{ppy}\right)_{2}(\mathrm{Phbpy})\right]\left[\mathrm{PF}_{6}\right] \cdot 2 \mathrm{MeC}_{6} \mathrm{H}_{5}$ confirms that the cation contains three $\pi$-stacking motifs in the coordination sphere of the iridium atom, two pyridine/phenyl contacts and one cyclometallating ring/phenyl interaction (Fig. 8c). 


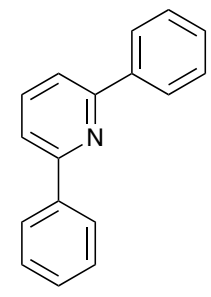

$\mathrm{H}\left(2,6-\mathrm{Ph}_{2} \mathrm{py}\right)$

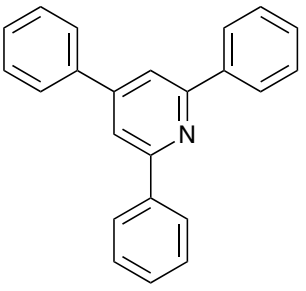

$\mathrm{H}\left(2,4,6-\mathrm{Ph}_{3} \mathrm{py}\right)$

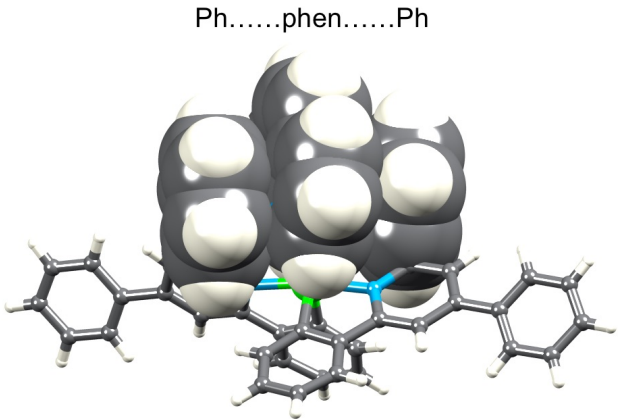

Fig. 7. The structures of the cyclometallating ligands $H\left(2,6-\mathrm{Ph}_{2} \mathrm{py}\right)$ and $H(2,4,6-$ $\mathrm{Ph}_{2}$ py) and the crystallographically determined structure of the cation in $\left[\operatorname{Ir}\left(2,4,6-\mathrm{Ph}_{3} \mathrm{py}_{2}\right.\right.$ (phen)][$\left[\mathrm{PF}_{6}\right] \cdot 4 \mathrm{H}_{2} \mathrm{O}$ (CSD refcode YODFII) [50].

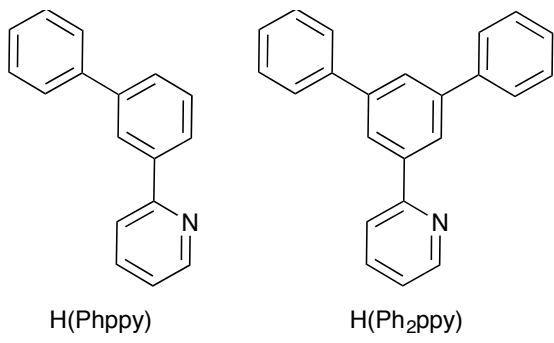

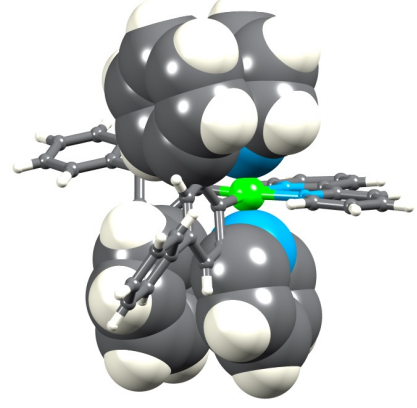

(a)

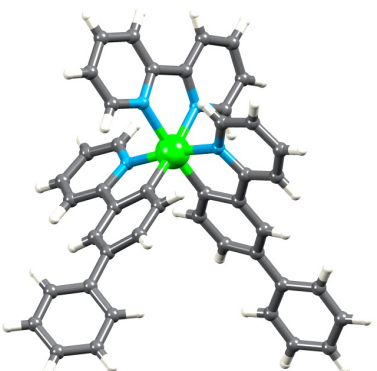

(b)

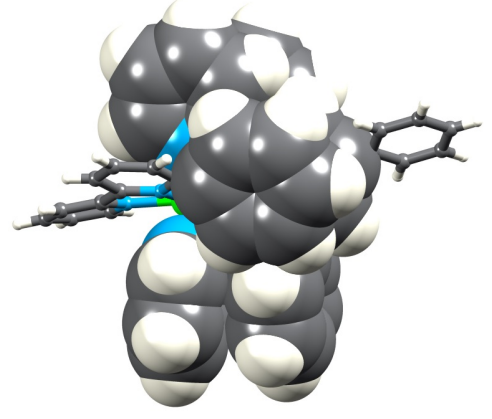

(c)

Fig. 8. The structures of the cyclometallating ligands $\mathrm{H}(\mathrm{Phppy})$ and $\mathrm{H}\left(\mathrm{Ph}_{2} \mathrm{ppy}\right)$; the structure of Phbpy is shown in Fig. 5. The cations in the structurally characterized (a) [Ir( $\mathrm{Ph}_{2}$ ppy) $)_{2}$ (bpy)] EtOH (CSD refcode BOYPAI), (b) $\left[\operatorname{Ir}(\mathrm{Phppy})_{2}\right.$ (bpy)] $\left[\mathrm{PF}_{6}\right]$ (CSD refcode BOYPEM) and (c) [Ir(Ph 2 ppy) $\left.)_{2}(\mathrm{Phbpy})\right]\left[\mathrm{PF}_{6}\right]$ (CSD refcode BOYPIQ) [36].

In addition to the examples given above, other combinations of $\mathrm{C}^{\wedge} \mathrm{N}$ and $\mathrm{N}^{\wedge} \mathrm{N}$ ligands that facilitate cyclometallating ring/aryl $\pi$-stacking within the coordination sphere of the metal in Ir-iTMCs have led to LECs showing enhanced stability $[51,52,53,54]$. In some cases, exceptional device lifetimes are observed and a contributing factor is the incorporation of peripheral, bulky substituents (see Section 5). Interestingly, red-emitting LECs using Ir-iTMCs in which the $\mathrm{N}^{\wedge} \mathrm{N}$ 
ligand is a bidentate $2,2^{\prime}: 6^{\prime}, 2$ "-terpyridine (tpy) with the pendant pyridyl group capable of engaging in cyclometallating ring/aryl $\pi$-stacking, show low efficiencies [55]. The application of the $\pi$-stacking strategy has been extended to Ir-iTMCs using an $N$-heterocyclic carbene ligand in place of the more usual diimine (Scheme 5). However, the results of DFT/TD-DFT calculations reveal that in this case, the inclusion of $\pi$-contacts does not provide a stabilizing effect in the iridium coordination sphere in both the ground and excited states of the Ir-iTMCs [56].

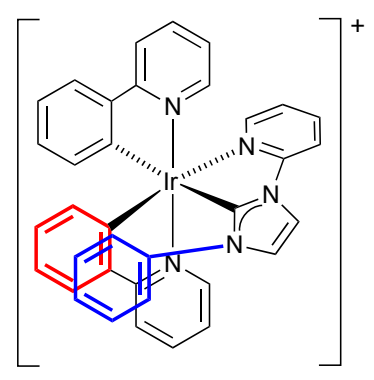

Scheme 5. Example of an Ir-iTMC using an $N$-heterocyclic carbene ligand functionalized with a phenyl group (shown in blue) for $\pi$-stacking with the cyclometallating ring (shown in red).

\section{Introduction of sterically-demanding substituents in the $\mathrm{N}^{\wedge} \mathrm{N}$ ligands}

\subsection{The effects of sterically-demanding substituents}

The discussion in Section 4 included several examples in which the $\mathrm{C}^{\wedge} \mathrm{N}$ ligands contained phenyl substituents in positions other than those adjacent to the metal-binding sites, for example, H(2,4,6-Ph 3 py) in Fig. 7 and H(Phppy) in Fig. 8. The introduction of bulky hydrophobic substituents on the periphery of Ir-iTMCs (e.g. in the 4- and 4'-positions of bpy) results in greater spatial separation of the $\left[\operatorname{Ir}\left(\mathrm{C}^{\wedge} \mathrm{N}\right)_{2}\left(\mathrm{~N}^{\wedge} \mathrm{N}\right)\right]^{+}$cations in the solid state. This militates against self-quenching and typically leads to an enhanced PLQY [3]. Common choices of substituent are tbutyl and phenyl (e.g. as in $\mathrm{H}\left(\mathrm{Phppy}\right.$ ) in Fig. 8). For $\mathrm{N}^{\wedge} \mathrm{N}$ ligands, many examples 
of 3,3'-, 4,4'- or 5,5'-disubstitution of bpy, or 4,7-disubstitution of phen have been reported, and such derivatization is expected to result in stable and efficient LECs.

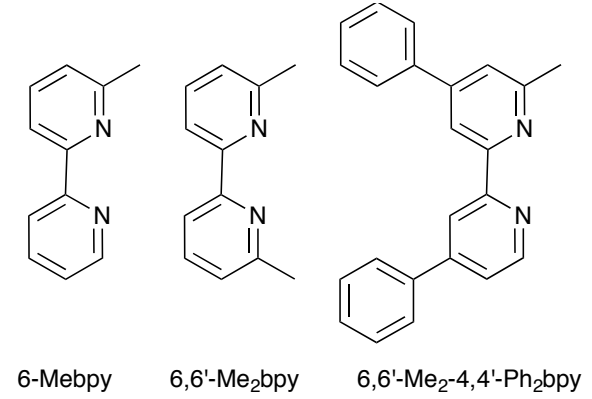

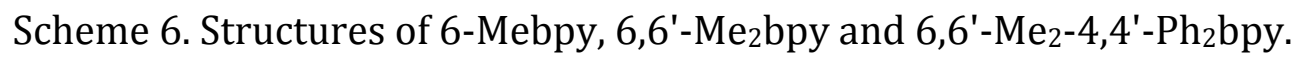

We have reported a systematic study of LECs with $\left[\operatorname{Ir}(\mathrm{ppy})_{2}(\mathrm{bpy})\right]\left[\mathrm{PF}_{6}\right]$, $\left[\operatorname{Ir}(\mathrm{ppy})_{2}(6-\mathrm{Mebpy})\right]\left[\mathrm{PF}_{6}\right],\left[\operatorname{Ir}(\mathrm{ppy})_{2}\left(6,6^{\prime}-\mathrm{Me}_{2} \mathrm{bpy}\right)\right]\left[\mathrm{PF}_{6}\right]$ or $\left[\operatorname{Ir}(\mathrm{ppy})_{2}\left(6,66^{\prime}-\mathrm{Me}_{2}-\right.\right.$ 4,4'-Ph ${ }_{2}$ bpy)] $\left[\mathrm{PF}_{6}\right]$ in the active layer (Scheme 6 shows the bpy ligands) [57]. Increased substitution has beneficial effects on the PL and emission lifetimes of the complexes. Thin films containing $\left[\operatorname{Ir}(\mathrm{ppy})_{2}(\mathrm{bpy})\right]\left[\mathrm{PF}_{6}\right]$ or $\left[\operatorname{Ir}(\mathrm{ppy})_{2}\left(6,6^{\prime}-\mathrm{Me}_{2}-\right.\right.$ 4,4'-Ph $\left.{ }_{2} \mathrm{bpy}\right]\left[\mathrm{PF}_{6}\right]$ and made with the same composition as in a LEC, exhibit PLQY values of $34 \%$ or $74 \%$, respectively. The LEC lifetime ( $t_{1 / 2}$ in Table 2$)$ is greatly improved $(7.8$ to $95 \mathrm{~h})$ on going from $\left[\operatorname{Ir}(\mathrm{ppy})_{2}(\mathrm{bpy})\right]\left[\mathrm{PF}_{6}\right]$ to $\left[\operatorname{Ir}(\mathrm{ppy})_{2}\left(6,6^{\prime}-\mathrm{Me}_{2}-4,4^{\prime}-\mathrm{Ph}_{2} \mathrm{bpy}\right)\right]\left[\mathrm{PF}_{6}\right]$ as the electroluminophore. It can be enhanced further by changing the ratio of Ir-iTMC : IL from $1: 1$ to $4: 1$. However, this is at the expense of the turn-on time of the device (Table 2). 
Table 2 Effects of substituents and use of ionic liquid on LEC performances in which the electroluminophore is based on [Ir(ppy) $\left.{ }_{2}(\mathrm{bpy})\right]\left[\mathrm{PF}_{6}\right]$ [57]; LEC configuration = ITO/PEDOT:PSS/Ir-iTMC:[BMIM] [PF6] $/$ Al.

\begin{tabular}{|c|c|c|c|}
\hline Electroluminophore & $t_{\mathrm{on}} / \mathrm{h}^{\mathrm{a}}$ & $L_{\max } / \mathrm{cd} \mathrm{m}^{-2}$ & $t_{1 / 2} / \mathrm{h}$ \\
\hline \multicolumn{4}{|c|}{ Ratio of Ir-iTMC:[BMIM] $\left[\mathrm{PF}_{6}\right]=1: 1$} \\
\hline$\left[\operatorname{Ir}(\mathrm{ppy})_{2}(\mathrm{bpy})\right]\left[\mathrm{PF}_{6}\right]$ & 0.04 & 375 & 7.8 \\
\hline$\left[\operatorname{Ir}(\mathrm{ppy})_{2}(6-\mathrm{Mebpy})\right]\left[\mathrm{PF}_{6}\right]$ & 4.4 & 194 & 28 \\
\hline$\left[\operatorname{Ir}(\mathrm{ppy})_{2}\left(6,6{ }^{\prime}-\mathrm{Me}_{2} \mathrm{bpy}\right)\right]\left[\mathrm{PF}_{6}\right]$ & 16 & 210 & 41 \\
\hline$\left[\operatorname{Ir}(\mathrm{ppy})_{2}\left(6,6^{\prime}-\mathrm{Me}_{2}-4,4^{\prime}-\mathrm{Ph}_{2} \mathrm{bpy}\right)\right]\left[\mathrm{PF}_{6}\right]$ & 11 & 240 & 95 \\
\hline \multicolumn{4}{|c|}{ Ratio of Ir-iTMC:[BMIM] $\left[\mathrm{PF}_{6}\right]=4: 1$} \\
\hline$\left[\operatorname{Ir}(\mathrm{ppy})_{2}(\mathrm{bpy})\right]\left[\mathrm{PF}_{6}\right]$ & 7.2 & 334 & 70 \\
\hline$\left[\operatorname{Ir}(\mathrm{ppy})_{2}(6-\mathrm{Mebpy})\right]\left[\mathrm{PF}_{6}\right]$ & 44 & 144 & 269 \\
\hline$\left[\operatorname{Ir}(\mathrm{ppy})_{2}\left(6,6^{\prime}-\mathrm{Me}_{2} \mathrm{bpy}\right)\right]\left[\mathrm{PF}_{6}\right]$ & 33 & 157 & 223 \\
\hline$\left[\operatorname{Ir}(\mathrm{ppy})_{2}\left(6,6^{\prime}-\mathrm{Me}_{2}-4,4^{\prime}-\mathrm{Ph}_{2} \mathrm{bpy}\right)\right]\left[\mathrm{PF}_{6}\right]$ & 37 & 190 & 356 \\
\hline
\end{tabular}

${ }^{\mathrm{a}} t_{\mathrm{on}}=$ time to reach maximum luminance

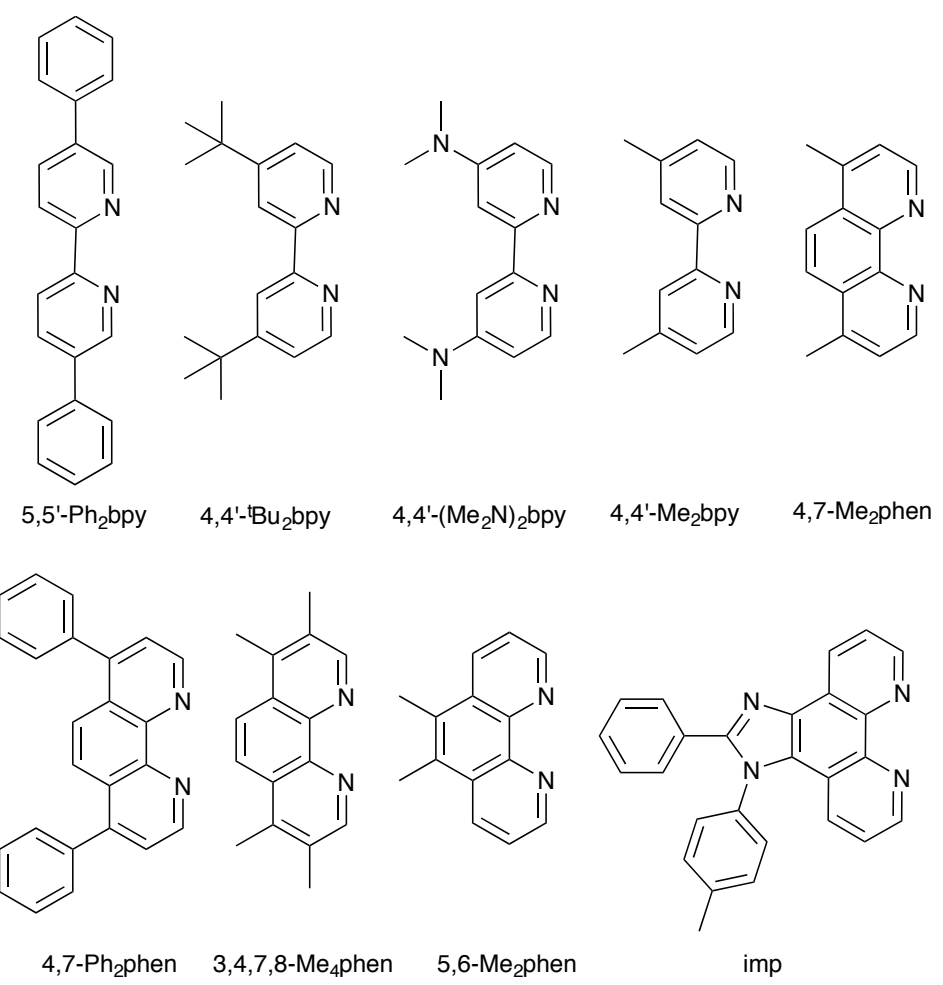

Scheme 7. Structures of variously substituted bpy and phen ligands.

The effects of introducing bulky substituents into the bpy or phen ligand in $\left[\operatorname{Ir}(\mathrm{ppy})_{2}(\mathrm{bpy})\right]\left[\mathrm{PF}_{6}\right]$ or $\left[\operatorname{Ir}(\mathrm{ppy})_{2}(\mathrm{phen})\right]\left[\mathrm{PF}_{6}\right]$ can be evaluated by looking at the results of a number of investigations, although one should bear in mind the different LEC configurations and operating conditions. Both the substituent and 
substitution pattern (Scheme 7) are important in terms of optimizing device performance. In 2011, Slinker, Zysman-Colman and coworkers confirmed the advantageous effects of introducing bulky 5,5'-substitutuents into the bpy ligand in $\left[\operatorname{Ir}(\text { ppy })_{2}(\mathrm{bpy})\right]^{+}[58]$. A LEC of configuration ITO/Ir-iTMC/Au containing $\left[\operatorname{Ir}(\mathrm{ppy})_{2}\left(5,5\right.\right.$ '-Ph $\left.\left.{ }_{2} \mathrm{bpy}\right)\right]\left[\mathrm{PF}_{6}\right]\left(5,5^{\prime}-\mathrm{Ph}_{2} \mathrm{bpy}\right.$, see Scheme 7) showed an EL maximum at $594 \mathrm{~nm}$ and had a value of $t_{1 / 2} \sim 107 \mathrm{~h}$. This LEC was more stable than a device with an analogous architecture but with $\left[\operatorname{Ir}(\mathrm{ppy})_{2}(4,4\right.$ '-

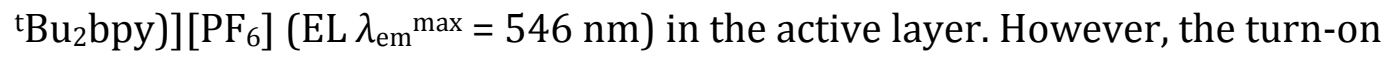
times show the reverse trend with values of $t_{\text {on }}$ (time to reach $L_{\max }$ ) being 140 and $2 \mathrm{~h}$ for LECs containing $\left[\operatorname{Ir}(\mathrm{ppy})_{2}\left(5,5 '-\mathrm{Ph}_{2} \mathrm{bpy}\right)\right]\left[\mathrm{PF}_{6}\right]$ and $\left[\operatorname{Ir}(\mathrm{ppy})_{2}\left(4,44^{\prime}-\right.\right.$

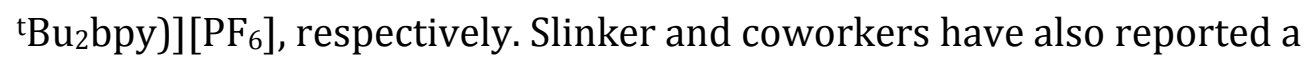
systematic investigation of the effects on introducing phenyl substituents into the 4,4'-positions of bpy, and the 4-positions of the phenyl or pyridyl rings in the $[p p y]^{-}$ligand in $\left[\operatorname{Ir}(\text { ppy })_{2}(\text { bpy) }]^{+}[59]\right.$. LECs in configuration ITO/PEDOT:PSS/iTMC + 0.3\% $\mathrm{LiPF}_{6} / \mathrm{LiF} / \mathrm{Al}$ were operated under a constant $12 \mathrm{~V}$ bias. Note the use of $\mathrm{LiPF}_{6}$ as an additive which has been shown to dramatically improve LEC performance by aiding the formation of electric double layers in the device. The incorporation of mobile $\mathrm{Li}^{+}$ions compensates for the poor mobility of the ions in the Ir-iTMC [60]. Table 3 details the structural variation in the complexes under investigation and their PL, EL and device characteristics. Addition of an electron-donating phenyl group to the cyclometallating ligand destabilizes the HOMO (see Fig. 2) and incorporating them into the bpy stabilizes the LUMO (see Fig. 2). As a result, a red-shift is seen in the solution emission compared to that of the archetype $\left[\operatorname{Ir}(\mathrm{ppy})_{2}(\mathrm{bpy})\right]\left[\mathrm{PF}_{6}\right]$. The exception to this trend is when the Ph group in introduced only into the pyridyl ring of the [ppy]- 
ligand. The trends in the EL maxima for the LECs follow those of the PL. Values of the solution PLQY were 14.4 to $26.5 \%$ and compared to $15.6 \%$ for $\left[\operatorname{Ir}(\mathrm{ppy})_{2}(\mathrm{bpy})\right]\left[\mathrm{PF}_{6}\right]$. In contrast to this relatively small PLQY range, there is significant variation in the performances of LECs with the different Ir-iTMCs in the active layer. The LEC data in Table 3 demonstrate that placing Ph groups in the 4-position of the [ppy]- pyridyl ring $\left(\mathrm{R}_{1}=\mathrm{Ph} ; \mathrm{R}_{2}=\mathrm{R}_{3}=\mathrm{H}\right.$ vs. $\left.\mathrm{R}_{1}=\mathrm{R}_{2}=\mathrm{R}_{3}=\mathrm{H}\right)$ leads to a doubling of $L_{\max }$ and a much faster $t_{\mathrm{on}}$. In contrast, use of $4,4{ }^{\prime}-\mathrm{Ph}_{2}$ bpy in place of bpy $\left(\mathrm{R}_{1}=\mathrm{R}_{2}=\mathrm{H} ; \mathrm{R}_{3}=\mathrm{Ph} v s . \mathrm{R}_{1}=\mathrm{R}_{2}=\mathrm{R}_{3}=\mathrm{H}\right)$ leads to a fall in $L_{\max }$ but a significant increase in LEC lifetime. In general, Ph substitution in the [ppy] ${ }^{-}$ domain leads to brighter LECs than substitution in the bpy unit [59]. 
Table 3. Summary of PL, EL and LEC performances in phenyl-substituted $\left[\operatorname{Ir}(\text { ppy })_{2}(\mathrm{bpy})\right]^{+} \operatorname{Ir}-\mathrm{iTMCs}[59]$.

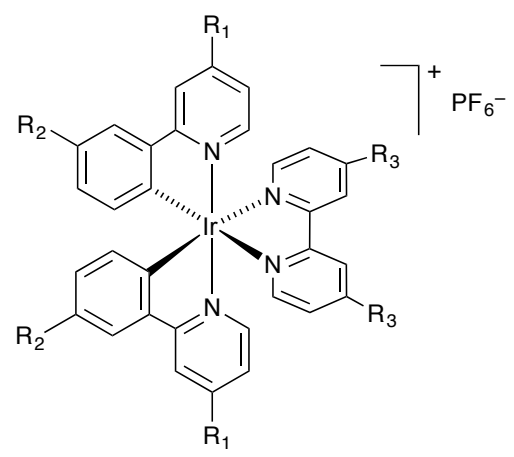

\begin{tabular}{lllllll}
\hline Substitution pattern & $\begin{array}{l}\text { Solution } \\
\text { PL } \lambda_{\text {max }} \\
/ \mathrm{nm}^{\mathrm{a}}\end{array}$ & $\begin{array}{l}\text { Solid- } \\
\text { state PL } \\
\lambda_{\mathrm{em}} \text { max }\end{array}$ & EL $/ \mathrm{nm}$ & $L_{\mathrm{max}} /$ & $t_{\mathrm{on}} / \mathrm{min}^{\mathrm{d}}$ & $t_{1 / 2} / \mathrm{h}^{\mathrm{e}}$ \\
$\mathrm{R}_{1}=\mathrm{R}_{2}=\mathrm{R}_{3}=\mathrm{H}$ & $598^{\mathrm{b}}$ & 544 & 599 & 2753 & 191 & 33 \\
$\mathrm{R}_{1}=\mathrm{R}_{2}=\mathrm{H} ; \mathrm{R}_{3}=\mathrm{Ph}$ & 604 & 618 & 613 & 382 & 17 & 232 \\
$\mathrm{R}_{1}=\mathrm{R}_{3}=\mathrm{H} ; \mathrm{R}_{2}=\mathrm{Ph}$ & 620 & 613 & 612 & 1725 & 6.5 & 2.9 \\
$\mathrm{R}_{1}=\mathrm{Ph} ; \mathrm{R}_{2}=\mathrm{R}_{3}=\mathrm{H}$ & 598 & 580 & 589 & 5425 & 4.9 & 9.6 \\
$\mathrm{R}_{1}=\mathrm{R}_{2}=\mathrm{Ph} ; \mathrm{R}_{3}=\mathrm{H}$ & 620 & 612 & 612 & 1310 & 2.3 & 2.7 \\
$\mathrm{R}_{1}=\mathrm{H} ; \mathrm{R}_{2}=\mathrm{R}_{3}=\mathrm{Ph}$ & 625 & 612 & 631 & 673 & 52 & 92 \\
$\mathrm{R}_{1}=\mathrm{R}_{3}=\mathrm{Ph} ; \mathrm{R}_{2}=\mathrm{H}$ & 605 & 620 & 623 & 744 & 116 & 46 \\
$\mathrm{R}_{1}=\mathrm{R}_{2}=\mathrm{R}_{3}=\mathrm{Ph}$ & 627 & 635 & 646 & 452 & 412 & 111
\end{tabular}

a In $\mathrm{CH}_{2} \mathrm{Cl}_{2}\left(\lambda_{\text {exc }}=295-315 \mathrm{~nm}\right)$; bValue compares with $595 \mathrm{~nm}$ previously reported in $\mathrm{CH}_{2} \mathrm{Cl}_{2}$

[41]; ${ }^{\mathrm{c}} \lambda_{\mathrm{exc}}=469$ or $470 \mathrm{~nm} ;{ }^{\mathrm{d}} t_{\mathrm{on}}=$ time to reach $L_{\max } ;{ }^{\mathrm{e}} t_{1 / 2}=$ time from $t_{\text {on }}\left(L_{\max }\right)$ to $L_{\max } / 2$.

The hydrophobicity and steric effects of the peripheral phenyl rings in the 4,7- $\mathrm{Ph}_{2}$ phen ligand are responsible for the long lifetime $\left(t_{1 / 2}=65 \mathrm{~h}\right)$ of a LEC with $\left[\operatorname{Ir}(\mathrm{ppy})_{2}\left(4,7-\mathrm{Ph}_{2}\right.\right.$ phen)] $\left[\mathrm{PF}_{6}\right]$ in the active layer (no IL). When Bolink et al. published this result in 2006, it represented a major breakthrough in the improvement of Ir-iTMC-based LEC stabilities [61]. Ligands based on $1 \mathrm{H}$ imidazo $[4,5-f][1,10]$ phenanthroline retain the phen metal-binding unit and have the synthetic advantage of ready tuning of the steric and electronic properties of 
the peripheral imidazole unit [62]. Tordera et al. explored the use of the ligand imp (Scheme 7) and reported efficient orange LECs with $\left[\operatorname{Ir}(\mathrm{ppy})_{2}(\mathrm{imp})\right]\left[\mathrm{PF}_{6}\right]$ in the active layer. The complex exhibits PL with $\lambda_{\mathrm{em}}{ }^{\max }=583 \mathrm{~nm}, \mathrm{PLQY}=43 \%$ and an excited-state lifetime of 910 ns. A LEC with configuration of ITO/PEDOT:PSS/Ir-iTMC:IL ( $4: 1) / \mathrm{Al}$ had a rapid $t_{\text {on }}$ of $45 \mathrm{~s}$ to attain a luminance of $100 \mathrm{~cd} \mathrm{~m}^{-2}$, and $28 \mathrm{~min}$ to reach $L_{\max }$ of $684 \mathrm{~cd} \mathrm{~m}^{-2}$. During $850 \mathrm{~h}$ of operation, the LEC lost only $20 \%$ of its peak efficacy $\left(6.5 \mathrm{~cd} \mathrm{~A}^{-1}\right)$ [63].

A comparison by Zysman-Colman and coworkers [64] of the performances of LECs containing $\left[\operatorname{Ir}(\mathrm{ppy})_{2}\left(4,4{ }^{\prime}-\mathrm{Bu}_{2} \mathrm{bpy}\right)\right]\left[\mathrm{PF}_{6}\right]$ or $\left[\operatorname{Ir}\left(\mathrm{Mesppy}_{2}\left(4,4{ }^{\prime}-\mathrm{Bu}_{2} \mathrm{bpy}\right)\right]\left[\mathrm{PF}_{6}\right]\right.$ (H(Mesppy) = 2-phenyl-4-mesitylpyridine) demonstrated that the peripheral mesityl groups lead to a much faster device turn-on $\left(<2 \mathrm{~s} v s .80 \mathrm{~s}\right.$ to reach $\left.L=100 \mathrm{~cd} \mathrm{~m}^{-2}\right)$. It was proposed that the mesityl groups aid electronic communication and allow faster charge hopping and recombination kinetics. The LECs had a configuration ITO/PEDOT:PSS/IriTMC:[BMIM][PF 6$](4: 1) / \mathrm{Al}$ and were operated under pulsed-current density driving. This investigation is also important in revealing differences between the use of racemic $(r a c)$ and enantiomerically pure $\Lambda$ - or $\Delta-\left[\operatorname{Ir}\left(\mathrm{C}^{\wedge} \mathrm{N}\right)_{2}\left(\mathrm{~N}^{\wedge} \mathrm{N}\right)\right]^{+}$ complexes. Two series of Ir-iTMCs were investigated: $r a c-, \Lambda$ - and $\Delta$ $\left[\operatorname{Ir}(\text { ppy })_{2}\left(4,4^{\prime}-\mathrm{tBu}_{2} \mathrm{bpy}\right)\right]\left[\mathrm{PF}_{6}\right]$ and $r a c^{-}, \Lambda$ - and $\Delta-\left[\operatorname{Ir}(\text { Mesppy })_{2}\left(4,4{ }^{\prime}-\right.\right.$ ${ }^{\text {tBu}}{ }_{2}$ bpy)] $\left[\mathrm{PF}_{6}\right]$. As expected, there is no difference between the solution PL within each rac-, $\Lambda$ - and $\Delta$-series $\left(\lambda_{\mathrm{em}}{ }^{\max }=577 \mathrm{~nm}\right.$ for all complexes $)$. However in thin film where packing effects are present, the emission of $r a c$ - $\left[\operatorname{Ir}(p p y)_{2}\left(4,4^{\prime}-\right.\right.$ $\left.\left.{ }^{\mathrm{t}} \mathrm{Bu}_{2} \mathrm{bpy}\right)\right]\left[\mathrm{PF}_{6}\right]$ is blue-shifted $\left(\lambda_{\mathrm{em}}{ }^{\max }=560 \mathrm{~nm}\right)$ with respect to each of $\Lambda$ - or $\Delta$ $\left[\operatorname{Ir}(\mathrm{ppy})_{2}\left(4,4^{\prime}-\mathrm{tBu}_{2} \mathrm{bpy}\right)\right]\left[\mathrm{PF}_{6}\right]\left(\lambda_{\mathrm{em}}^{\max }=582 \mathrm{~nm}\right)$. For $\left[\operatorname{Ir}(\mathrm{Mesppy})_{2}\left(4,4^{\prime}-\right.\right.$ ${ }^{\text {tBu}}{ }_{2}$ bpy)] $\left[\mathrm{PF}_{6}\right]$, a broad emission with $\lambda_{\mathrm{em}}{ }^{\mathrm{max}}=550 \mathrm{~nm}$ with shoulders at 478 and 
$516 \mathrm{~nm}$ is observed for the rac-species, while the $\Lambda$ - and $\Delta$-enantiomers in thin film exhibit structured and blue-shifted emissions $\left(\lambda_{\mathrm{em}}{ }^{\max }=511,480 \mathrm{~nm}\right)$. LECs with $r a c^{-}, \Lambda$ - and $\Delta$-[ $\left.\operatorname{Ir}(\mathrm{ppy})_{2}\left(4,4^{\prime}-\mathrm{tBu}_{2} \mathrm{bpy}\right)\right]\left[\mathrm{PF}_{6}\right]$ in the active layer are all longlived with extrapolated values of $t_{1 / 2}$ of $>1300 \mathrm{~h}(\mathrm{rac}),>700 \mathrm{~h}(\Lambda)$ and $>400 \mathrm{~h}(\Delta)$. As the authors point out [64], comparisons between these results and earlier reports of LECs based on $r a c-\left[\operatorname{Ir}(\mathrm{ppy})_{2}\left(4,4^{\prime}-\mathrm{tBu}_{2} \mathrm{bpy}\right)\right]\left[\mathrm{PF}_{6}\right]$ are difficult because of variations in LEC operating conditions.

In general, peripheral bulky substituents are beneficial in terms of LEC performance, and in the next section, we look at the effects of combining this strategy with that of introducing $\pi$-stacking interactions (see Section 4) within the coordination sphere of the iridium atom.

\subsection{Combining sterically-demanding substituents with intramolecular} $\pi$-stacking

In Section 4, the advantageous effects of $\pi$-stacking effects within the coordination sphere of the iridium atom were demonstrated. An outstanding example was the exceptional LEC stability found for [ $\left.\operatorname{Ir}\left(\mathrm{Ph}_{2} \mathrm{ppy}\right)_{2}(\mathrm{Phbpy})\right]\left[\mathrm{PF}_{6}\right]$ in the active layer with a lifetime $>2800 \mathrm{~h}[36]$. The ligands in this complex combine the strategies of having peripheral bulky substituents and $\pi$-stacking interactions. Other examples of this combined approach also demonstrate outstanding LEC performances. Scheme 8 shows a series of ligands derived from 6-phenyl-2,2'-bipyridine (Hbpy) in which the 4-position carries particularly bulky groups. Inclusion of the 6-phenyl ring ensures intra-cation $\pi$-stacking in each $\left[\operatorname{Ir}(\text { ppy })_{2}\left(\mathrm{ZC}_{6} \mathrm{H}_{4} \mathrm{bpy}\right)\right]^{+}$or $\left[\operatorname{Ir}(\mathrm{ppy})_{2}\left(\mathrm{Z}_{2} \mathrm{C}_{6} \mathrm{H}_{3} \mathrm{bpy}\right)\right]^{+}$derivative $(\mathrm{Z}=$ substituent). LECs with $\left[\operatorname{Ir}(\mathrm{ppy})_{2}(\mathrm{Phbpy})\right]\left[\mathrm{PF}_{6}\right]$, 
$\left[\operatorname{Ir}(\text { ppy })_{2}\left\{(\mathrm{MeO})_{2} \mathrm{C}_{6} \mathrm{H}_{3}\right.\right.$ bpy $\left.\}\right]\left[\mathrm{PF}_{6}\right],\left[\operatorname{Ir}(\text { ppy })_{2}\left\{(\text { decylO })_{2} \mathrm{C}_{6} \mathrm{H}_{3}\right.\right.$ bpy $\left.\}\right]\left[\mathrm{PF}_{6}\right]$ or

$\left[\operatorname{Ir}(\mathrm{ppy})_{2}(\mathrm{dendbpy})\right]\left[\mathrm{PF}_{6}\right]$ blended with the ionic liquid $[\mathrm{BMIM}]\left[\mathrm{PF}_{6}\right]$ in the active layer (Ir-iTMC : [BMIM] $\left[\mathrm{PF}_{6}\right]=4: 1$ ) were operated with a constant voltage of 3

V. Their performances were significantly influenced by the steric demands of the 4-substituent in the $\mathrm{N}^{\wedge} \mathrm{N}$ ligand [51]. While the value of $L_{\max }$ increases along the series Phbpy $\left(109 \mathrm{~cd} \mathrm{~m}^{-2}\right)<(\mathrm{MeO})_{2} \mathrm{C}_{6} \mathrm{H}_{3}$ bpy $\left(183 \mathrm{~cd} \mathrm{~m}^{-2}\right)<(\text { decylO })_{2} \mathrm{C}_{6} \mathrm{H}_{3}$ bpy $\left(284 \mathrm{~cd} \mathrm{~m}^{-2}\right)$, the introduction of the dendritic wedge in dendbpy gave a LEC that failed to turn on after $48 \mathrm{~h}$ under a $3 \mathrm{~V}$ or $4 \mathrm{~V}$ bias. All LECs were very slow to turn-on $\left(237 \mathrm{~h}\right.$ for $\left[\operatorname{Ir}(\mathrm{ppy})_{2}(\mathrm{Phbpy})\right]\left[\mathrm{PF}_{6}\right]$ to $33 \mathrm{~h}$ for $\left[\operatorname{Ir}(\text { ppy })_{2}\left\{(\text { decylO })_{2} \mathrm{C}_{6} \mathrm{H}_{3}\right.\right.$ bpy $\left.\left.\}\right]\left[\mathrm{PF}_{6}\right]\right) ;$ the slow turn-on of the LEC with $\left[\operatorname{Ir}(\mathrm{ppy})_{2}(\mathrm{Phbpy})\right]\left[\mathrm{PF}_{6}\right]$ in the emissive layer was also observed in a separate investigation [46]. A possible explanation is the formation of crystalline zones in the spin-coated thin films in the active layers. LEC lifetimes show a dependence upon the peripheral substituent: $t_{1 / 2}=1290 \mathrm{~h}$ for $\left[\operatorname{Ir}(\mathrm{ppy})_{2}(\mathrm{Phbpy})\right]\left[\mathrm{PF}_{6}\right], 950 \mathrm{~h}$ for $\left[\operatorname{Ir}(\mathrm{ppy})_{2}\left\{(\mathrm{MeO})_{2} \mathrm{C}_{6} \mathrm{H}_{3}\right.\right.$ bpy $\left.\}\right]\left[\mathrm{PF}_{6}\right]$ and $660 \mathrm{~h}$ for $\left[\operatorname{Ir}(\text { ppy })_{2}\left\{(\text { decylO })_{2} \mathrm{C}_{6} \mathrm{H}_{3}\right.\right.$ bpy $\left.\}\right]\left[\mathrm{PF}_{6}\right]$. Under conditions of a constant bias driving mode, this study [51] achieved efficient and long-lived orange-emitting LECs with electroluminophores featuring the protective intra-cation $\pi$-stacking motif. Although shorter turn-on times were observed when bulky peripheral groups were present, excessive steric demand appears to lead to too great an intercomplex separation in the active layer and a failure of the LEC to function.

The development of a pulsed current driving mode for LECs $[65,66]$ has an advantageous effect on turn-on times and stabilizes the doped regions in the 
LEC leading to longer lifetimes. Extension of the series of ligands discussed above to $\mathrm{Ph}_{2} \mathrm{Ndendbpy}$ (Scheme 8) demonstrated not only the advantages of the combined effects of sterically-demanding substituents with intramolecular $\pi$ stacking, but also the use of a pulsed driving mode. A LEC in configuration ITO/PEDOT:PSS/Ir-iTMC:IL (4 : 1)/Al reached $L=75 \mathrm{~cd} \mathrm{~m}^{-2}$ in $0.4 \mathrm{~h}\left(L_{\max }=83 \mathrm{~cd}\right.$ $\mathrm{m}^{-2}$ ) and showed a value of $t_{1 / 2}=250 \mathrm{~h}$ [67]. Interestingly, LECs in the same configuration as the latter but with $\left[\operatorname{Ir}(\mathrm{ppy})_{2}\left(\mathrm{BrC}_{6} \mathrm{H}_{4} \mathrm{bpy}\right)\right]\left[\mathrm{PF}_{6}\right]$ or $\left[\operatorname{Ir}(\mathrm{ppy})_{2}\left(\mathrm{Br}_{2} \mathrm{C}_{6} \mathrm{H}_{3} \mathrm{bpy}\right)\right]\left[\mathrm{PF}_{6}\right]$ as electroluminophore show fast turn-on times and moderate $L_{\max }$ values (115 and $101 \mathrm{~cd} \mathrm{~m}^{-2}$, respectively) but only have short lifetimes (8.3 and $2.9 \mathrm{~h}$, respectively) [67]. The reasons for this behaviour are unclear, but the same trend has also been observed in a series of copper-based LECs in which the $\mathrm{N}^{\wedge} \mathrm{N}$ ligand bears bromo-substituents [68].

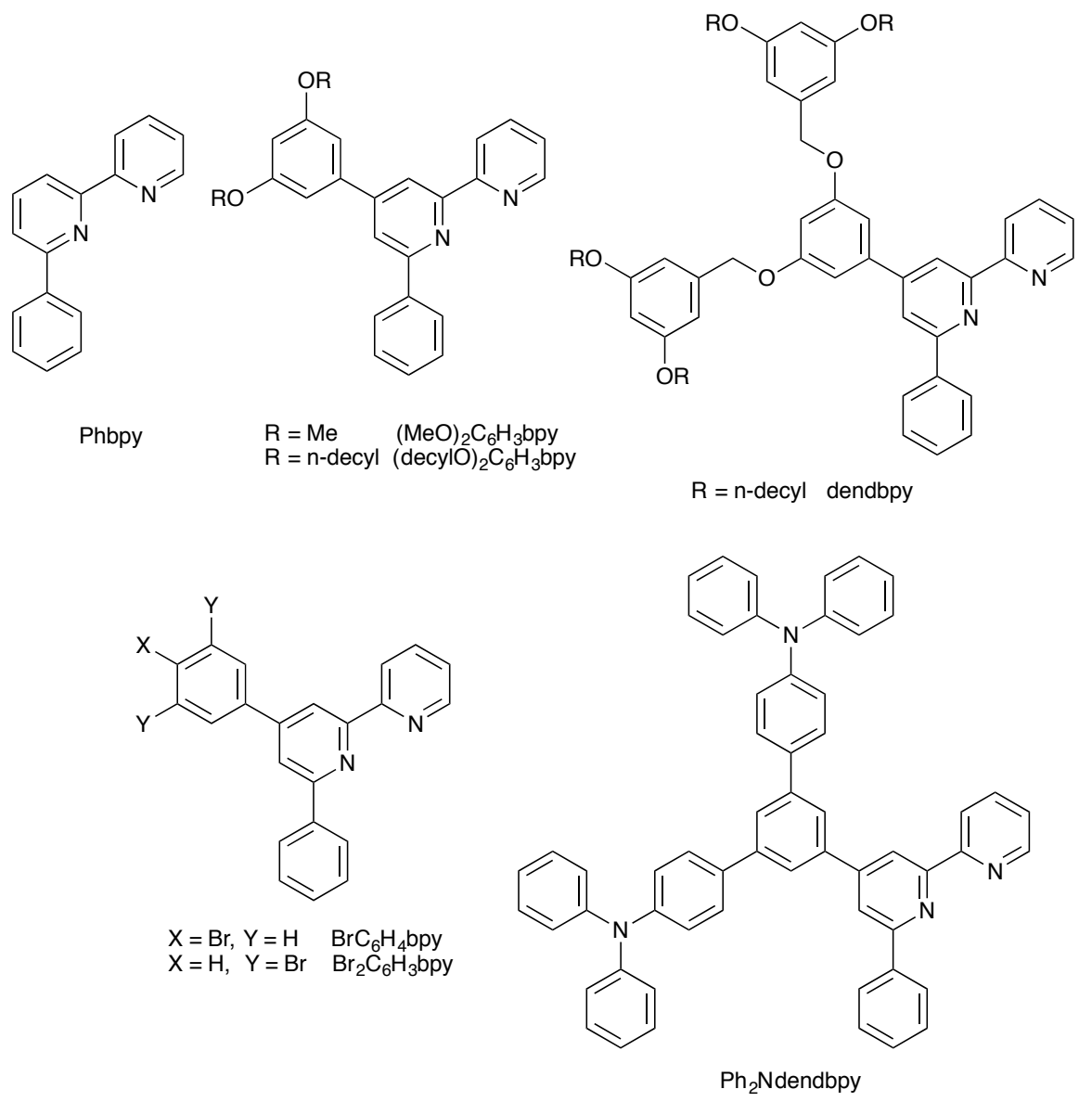


Scheme 8. 6-Phenyl-2,2'-bipyridine (Phbpy) and related ligands bearing bulky 4substituents.

\section{Blue-shifting the emission}

In the last two sections, we focused on strategies for improving LEC stability and turn-on times. We now move to approaches for tuning the emission colour. As stated in the introduction, many orange-emitting Ir-iTMCs are known and most of the complexes decribed in the previous section give rise to orange emissions. Complementary deep-blue emitters are essential in order to achieve white-lightemitting LECs by colour-blending. It is also desirable to develop highly-stable deep-red emitters (see Section 7). The partitioning of HOMO and LUMO character of an $\left[\operatorname{Ir}\left(\mathrm{C}^{\wedge} \mathrm{N}\right)_{2}\left(\mathrm{~N}^{\wedge} \mathrm{N}\right)\right]^{+}$complex on the $\operatorname{Ir} / \mathrm{C}^{\wedge} \mathrm{N}$ or $\mathrm{N}^{\wedge} \mathrm{N}$ domains (Fig. 2) is one of the appeals of this class of compound since it allows emission colourtuning by variation of the electronic properties of the $\mathrm{C}^{\wedge} \mathrm{N}$ and/or $\mathrm{N}^{\wedge} \mathrm{N}$ domains. For example, attaching electron-withdrawing substituents to the $\mathrm{C}^{\wedge} \mathrm{N}$ ligand reduces the $\sigma$-donation from the cyclometallating ligand to the iridium centre, resulting in a lowering of the energy of the HOMO (recall that the HOMO is localized on the $\left\{\operatorname{Ir}\left(\mathrm{C}^{\wedge} \mathrm{N}\right)_{2}\right\}$ domain). However, attaining blue solution PL by careful design of ligands in a $\left[\operatorname{Ir}\left(\mathrm{C}^{\wedge} \mathrm{N}\right)_{2}\left(\mathrm{~N}^{\wedge} \mathrm{N}\right)\right]^{+}$complex is, unfortunately, not a prerequisite for blue EL from a LEC containing the same emitting species. A redshift on going from PL to EL is often observed for wide-bandgap electroluminophores. It is thought that this phenomenon may arise from morphological effects and light-out coupling effects [69].

There are two general approaches to attaining blue-emitters: attaching electron-withdrawing substituents to the $\mathrm{C}^{\wedge} \mathrm{N}$ ligand or the use of nitrogen-rich 
heterocyclic ligands. While we describe these approaches below in separate sections to aid the reader, the tendency for investigations to include comparisons of series of compounds as well as the use of more than one structure-property strategy within a single compound, leads to an unavoidable overlap of topics within Sections 6.1-6.4.

\subsection{Introducing fluoro-substituents into cyclometallating ligands}

The presence of electron-withdrawing groups in the cyclometallating ligands in $\left[\operatorname{Ir}\left(\mathrm{C}^{\wedge} \mathrm{N}\right)_{2}\left(\mathrm{~N}^{\wedge} \mathrm{N}\right)\right]^{+}$complexes lowers the energy of the HOMO, thereby increasing the energy of emission with a concomitant shift towards the blue. Fluorosubstituents are the most common choice and Scheme 9 shows the structures of selected fluorinated Hppy ligands.
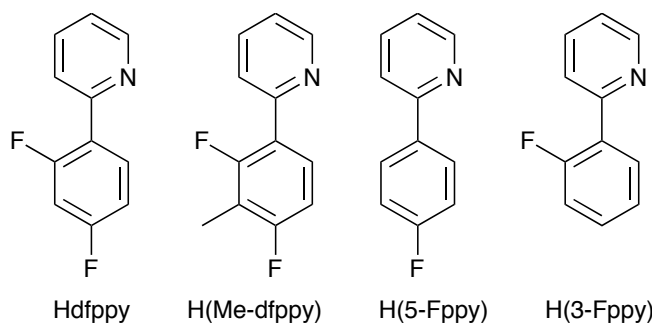

H(3-Fppy)

Scheme 9. Structures of fluoro-derivatives of Hppy.

In 2007, Bolink et al. showed that [Ir(dfppy) $)_{2}\left(3,4,7,8-\mathrm{Me}_{4}\right.$ phen)] $\left[\mathrm{PF}_{6}\right]$ (see Schemes 7 and 9) emitted blue light (PL $\lambda_{\mathrm{em}}{ }^{\max }=476 \mathrm{~nm}$ in thin film) with a PLQY of 52\%. A LEC in configuration ITO/Ir-iTMC/Al under a bias of $3 \mathrm{~V}$ reached a current efficiency of $5.5 \mathrm{~cd} \mathrm{~A}^{-1}$. However, the EL maximum was red-shifted by $80 \mathrm{~nm}$ with respect to the PL, leading to a green-emitting LEC. The results of DFT and TD-DFT calculations revealed that $\left[\operatorname{Ir}(\mathrm{dfppy})_{2}\left(3,4,7,8-\mathrm{Me}_{4} \text { phen }\right)\right]^{+}$possesses 
three low-energy triplet states which differ by only $0.1 \mathrm{eV}$, leading to respective emission wavelengths differing by $\sim 60 \mathrm{~nm}$. One triplet state leads to a green emission, while two lead to more blue-shifted emissions $[69,70]$. The solution PL maximum for the related complex $\left[\operatorname{Ir}(\mathrm{dfppy})_{2}\left(2,9-{ }^{\mathrm{n}} \mathrm{Bu}_{2}\right.\right.$ phen $\left.)\right]\left[\mathrm{PF}_{6}\right](2,9-$ ${ }^{n} \mathrm{Bu}_{2}$ phen $=2,9-$ di-n butyl-1,10-phenanthroline) is at $492 \mathrm{~nm}$, and a red-shift to $502 \mathrm{~nm}$ is observed on going to the EL of a LEC in configuration ITO/PEDOT:PSS/Ir-iTMC/Al [71].

The series $\left[\operatorname{Ir}(5-\mathrm{Fppy})_{2}\left(4,4^{\prime}-\mathrm{tBu}_{2} \mathrm{bpy}\right)\right]\left[\mathrm{PF}_{6}\right],\left[\operatorname{Ir}(3-\mathrm{Fppy})_{2}\left(4,4^{\prime}-\right.\right.$

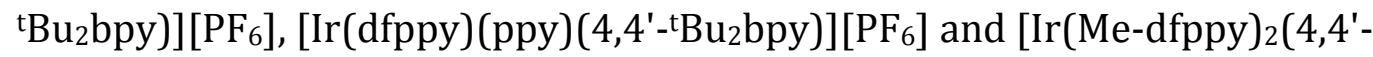
${ }^{\text {tBu}}{ }_{2}$ bpy)] $\left[\mathrm{PF}_{6}\right]$ combine the effects of bulky substituents in the $\mathrm{N}^{\wedge} \mathrm{N}$ domain with electron-withdrawing fluoro-substituents in the cyclometallating ligand. Although these were green rather than blue emitters, the results are important for demonstrating the effects of incorporating different numbers of fluorogroups. [Ir(5-Fppy $)_{2}\left(4,4^{\prime}-\mathrm{BBu}_{2}\right.$ bpy $\left.)\right]^{+},\left[\operatorname{Ir}(3-\mathrm{Fppy})_{2}\left(4,4^{\prime}-\mathrm{tBu}_{2} \text { bpy }\right)\right]^{+}$and $\left[\operatorname{Ir}(\mathrm{dfppy})(\mathrm{ppy})\left(4,4^{\prime}-\mathrm{tBu}_{2} \mathrm{bpy}\right)\right]^{+}$contain two $\mathrm{F}$ atoms (either as two monosubstituted $\mathrm{C}^{\wedge} \mathrm{N}$ ligands or as one disubstituted $[\mathrm{dfppy}]^{-}$), while $[\operatorname{Ir}(\mathrm{Me}-$ dfppy $\left.)_{2}\left(4,4^{\prime}-\mathrm{Bu}_{2} \mathrm{bpy}\right)\right]^{+}$has four $\mathrm{F}$ atoms. The variation in substituents has negligible effect on the PL ( $\left.\lambda_{\mathrm{em}}{ }^{\max }=552-555 \mathrm{~nm}\right)$ and PLQY (52-69\%), and the maximum luminances of LECs in configuration ITO/PEDOT:PSS/IriTMC:[BMIM] $\left[\mathrm{PF}_{6}\right](4: 1) / \mathrm{Al}$ and operated using a pulsed current were similar $\left(L_{\max }=1028-1095 \mathrm{~cd} \mathrm{~m}^{-2}\right)$. However, the stability of the LECS over time showed significant variation. LECs with $\left[\operatorname{Ir}(5-\mathrm{Fppy})_{2}\left(4,4^{\prime}-\mathrm{BBu}_{2} \mathrm{bpy}\right)\right]\left[\mathrm{PF}_{6}\right],[\operatorname{Ir}(3-$ Fppy $\left.)_{2}\left(4,4^{\prime}-{ }^{-} \mathrm{Bu}_{2} \mathrm{bpy}\right)\right]\left[\mathrm{PF}_{6}\right]$ or $\left[\operatorname{Ir}(\mathrm{dfppy})(\mathrm{ppy})\left(4,4^{\prime}-{ }^{\mathrm{t}} \mathrm{Bu}_{2} \mathrm{bpy}\right)\right]\left[\mathrm{PF}_{6}\right]$ in the active layer had $t_{1 / 2}=59.8,48.3$ or $55.0 \mathrm{~h}$, respectively. A shorter lifetime of $13.2 \mathrm{~h}$ was observed for the LEC containing [Ir(Me-dfppy) ${ }_{2}\left(4,4^{\prime}-{ }^{-} \mathrm{Bu}_{2} \text { bpy) }\right]^{+}$(four F atoms) 
[72]. The instability of fluorine-containing emitters has also been described for neutral iridium(III) complexes used in OLEDs [73,74]. Overall, the results encourage the development of fluorine-free blue-emitting electroluminophores (see Section 6.2). Nonetheless, the use of simple fluoro electron-withdrawing groups is widely applied, and further examples, especially the use of H(dfppy), are included in Sections 6.3 and 6.4.

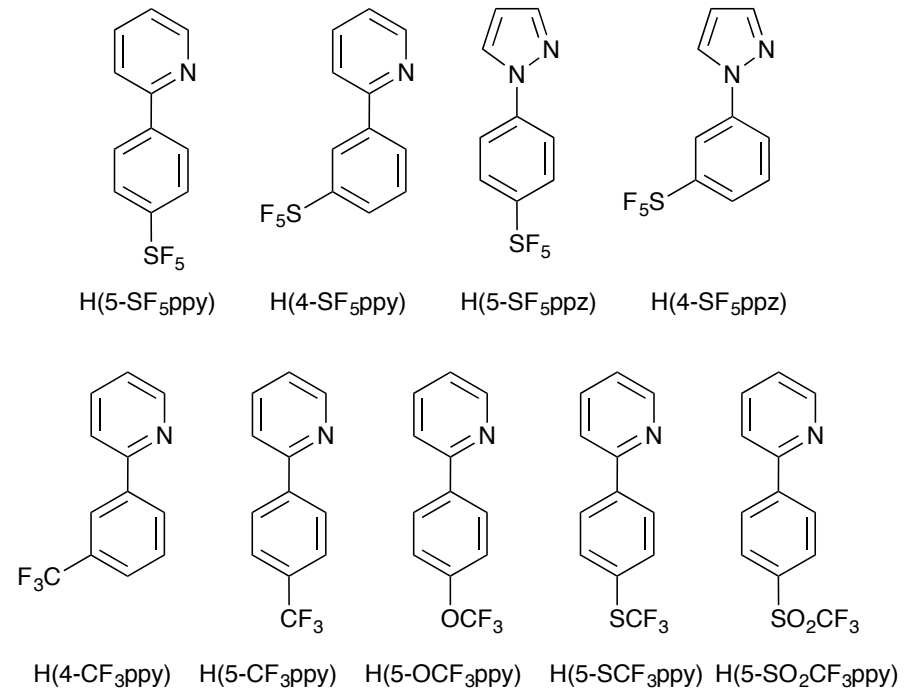

Scheme 10. Cyclometallating ligands with electron-withdrawing $\mathrm{SF}_{5}$ or $\mathrm{CF}_{3}$ substituents or $\mathrm{CF}_{6}$-containing substituents $(\mathrm{Hppz}=1$-phenyl- $1 H$-pyrazole, see Section 6.3).

Introducing the strongly electron-withdrawing $\mathrm{SF}_{5}$ substituent into the phenyl ring of Hppy (Scheme 10) leads to MeCN solution PL $\lambda_{\mathrm{em}}{ }^{\text {max }}$ values of 482 and $496 \mathrm{~nm}$ for $\left[\operatorname{Ir}\left(5-\mathrm{SF}_{5} \text { ppy }\right)_{2}\left(4,4{ }^{\prime}-{ }^{-} \mathrm{Bu}_{2} \mathrm{bpy}\right)\right]\left[\mathrm{PF}_{6}\right]$ and $\left[\operatorname{Ir}\left(4-\mathrm{SF}_{5} \mathrm{ppy}\right)_{2}\left(4,4^{\prime}-\right.\right.$ $\left.\left.{ }^{t} \mathrm{Bu}_{2} \mathrm{bpy}\right)\right]\left[\mathrm{PF}_{6}\right]$, respectively, demonstrating the effects of regioisomerism in the functionalized $\mathrm{C}^{\wedge} \mathrm{N}$ ligand. On going from Hppy to Hppz-based ligands (Scheme $10)$, this effect is smaller with $\left[\operatorname{Ir}\left(5-\mathrm{SF}_{5} \mathrm{ppz}\right)_{2}\left(4,4^{\prime}-{ }^{-} \mathrm{Bu}_{2} \mathrm{bpy}\right)\right]\left[\mathrm{PF}_{6}\right]$ and $[\operatorname{Ir}(5-$ 
$\left.\left.\mathrm{SF}_{5} \mathrm{ppz}\right)_{2}\left(4,4^{\prime}-{ }^{-} \mathrm{Bu}_{2} \mathrm{bpy}\right)\right]\left[\mathrm{PF}_{6}\right]$ exhibiting $\mathrm{PL} \lambda_{\mathrm{em}}{ }^{\max }=505$ and $500 \mathrm{~nm}$, respectively in MeCN. The solution emission is solvent dependent, shifting to 497 and 494 nm, respectively, on going to $\mathrm{CH}_{2} \mathrm{Cl}_{2}$. These blue/blue-green emissions appear promising, but disappointingly, LECs in configuration ITO/PEDOT:PSS/IriTMC:[BMIM][PF 6$]$ (4:1)/Al and operated using a pulsed current mode showed no EL; this was attributed to the electrochemical instability of the $\mathrm{SF}_{5}$ group [75]. The effects of incorporating the electron-withdrawing $\mathrm{CF}_{3}$ group in Ir-iTMCs were first reported in 2013 in a comparative investigation of [ $\operatorname{Ir}\left(4-\mathrm{CF}_{3} p p y\right)_{2}\left(4,4^{\prime}-\right.$ $\left.\left.\mathrm{Me}_{2} \mathrm{bpy}\right)\right]\left[\mathrm{PF}_{6}\right],\left[\operatorname{Ir}\left(4-\mathrm{CF}_{3} \text { ppy }\right)_{2}\left(4,4{ }^{\prime}-\mathrm{Bu}_{2} \mathrm{bpy}\right)\right]\left[\mathrm{PF}_{6}\right],\left[\operatorname{Ir}\left(4-\mathrm{CF}_{3} \mathrm{ppy}\right)_{2}(\mathrm{phen})\right]\left[\mathrm{PF}_{6}\right]$, $\left[\operatorname{Ir}\left(4-\mathrm{CF}_{3} \text { ppy }\right)_{2}\left(4,7-\mathrm{Me}_{2}\right.\right.$ phen $\left.)\right]\left[\mathrm{PF}_{6}\right]$ and $\left[\operatorname{Ir}\left(4-\mathrm{CF}_{3} \mathrm{ppy}\right)_{2}\left(4,7-\mathrm{Ph}_{2}\right.\right.$ phen $\left.)\right]\left[\mathrm{PF}_{6}\right]$ (see Schemes 7 and 10 for ligands) [76]. Solution PL $\left(\mathrm{CH}_{2} \mathrm{Cl}_{2}\right)$, LEC EL and performance data are summarized in Table 4. Values of PLQY range from 61$67 \%$ in solution, but are lower (14-43\%) in thin films. The presence of the $\mathrm{CF}_{3}$ group leads to blue-shifted solution PL (e.g. compare $530 \mathrm{~nm}$ for $\left.\left[\operatorname{Ir}(\mathrm{ppy})_{2}(\mathrm{phen})\right]\left[\mathrm{PF}_{6}\right][40]\right)$. The solution PL maxima correspond to blue-green emission for $\left[\operatorname{Ir}\left(4-\mathrm{CF}_{3} \mathrm{ppy}\right)_{2}\left(4,7-\mathrm{Me}_{2}\right.\right.$ phen $\left.)\right]\left[\mathrm{PF}_{6}\right]$, green emissions for $[\operatorname{Ir}(4-$ $\left.\left.\mathrm{CF}_{3} \mathrm{ppy}\right)_{2}\left(4,44^{\prime}-\mathrm{Me}_{2} \mathrm{bpy}\right)\right]\left[\mathrm{PF}_{6}\right],\left[\operatorname{Ir}\left(4-\mathrm{CF}_{3} \mathrm{ppy}\right)_{2}\left(4,4\right.\right.$ '-tBu $\left.\left.{ }_{2} \mathrm{bpy}\right)\right]\left[\mathrm{PF}_{6}\right]$ and $[\operatorname{Ir}(4-$ $\left.\left.\mathrm{CF}_{3} \mathrm{ppy}\right)_{2}(\mathrm{phen})\right]\left[\mathrm{PF}_{6}\right]$, and yellow-green emission for $\left[\operatorname{Ir}\left(4-\mathrm{CF}_{3} \mathrm{ppy}\right)_{2}(4,7-\right.$ $\mathrm{Ph}_{2}$ phen)][PF 6$]$. LECs with these compounds in the active layer all show greenyellow electroluminescence (Table 4) which is blue-shifted with respect to EL when the $\mathrm{CF}_{3}$ group is absent. As the data in Table 4 demonstrate, the performances of the LECs are strongly influenced by the operating conditions (constant voltage or pulsed current mode), in particular the turn-on time to reach a luminance of $100 \mathrm{~cd} \mathrm{~m}^{-2}$ and the device stability. Zysman-Colman and coworkers have carried out a systemic investigation of the Ir-iTMCs 
$\left[\operatorname{Ir}\left(\mathrm{C}^{\wedge} \mathrm{N}\right)_{2}\left(4,4^{\prime}-\mathrm{Bu}_{2} \mathrm{bpy}\right)\right]\left[\mathrm{PF}_{6}\right]$ in which the cyclometallating ligands are $\mathrm{H}(5-$

$\mathrm{CF}_{3}$ ppy), $\mathrm{H}\left(5-\mathrm{OCF}_{3}\right.$ ppy), $\mathrm{H}\left(5-\mathrm{SCF}_{3}\right.$ ppy) and $\mathrm{H}\left(5-\mathrm{SO}_{2} \mathrm{CF}_{3}\right.$ ppy) (Scheme 10) [77]. A small regioisomeric effect on the solution PL $\left(\mathrm{CH}_{2} \mathrm{Cl}_{2}\right)$ is observed on going from $\left[\operatorname{Ir}\left(4-\mathrm{CF}_{3} \text { ppy }\right)_{2}\left(4,4^{\prime}-\mathrm{Me}_{2} \mathrm{bpy}\right)\right]\left[\mathrm{PF}_{6}\right]\left(\lambda_{\mathrm{em}}{ }^{\max }=512 \mathrm{~nm}\right)[76]$ to $\left[\operatorname{Ir}\left(5-\mathrm{CF}_{3} \mathrm{ppy}\right)_{2}\left(4,4^{\prime}-\right.\right.$ $\left.\left.\mathrm{Me}_{2} \mathrm{bpy}\right)\right]\left[\mathrm{PF}_{6}\right]\left(\lambda_{\mathrm{em}}{ }^{\max }=517 \mathrm{~nm}\right)$ [77]. Of the series in this study [77], the PL of $\left[\operatorname{Ir}\left(5-\mathrm{CF}_{3} \mathrm{ppy}\right)_{2}\left(4,4^{\prime}-\mathrm{Me}_{2} \mathrm{bpy}\right)\right]\left[\mathrm{PF}_{6}\right]$ is the most blue-shifted, and this is also true for the EL of LECs in configuration ITO/PEDOT:PSS/Ir-iTMC:[BMIM][PF 6 ] (4:1)/Al. For a given electroluminophore, the EL maximum was red-shifted with respect to the PL, leading to values of EL $\lambda_{\mathrm{em}}{ }^{\text {max }}$ in the range $556-568 \mathrm{~nm}$ (greenyellow emission). The LECs were operated under a pulsed-current (50 or $100 \mathrm{~A}$ $\left.\mathrm{m}^{-2}\right)$ mode and the brightest device was with $\left[\operatorname{Ir}\left(4-\mathrm{CF}_{3} \mathrm{ppy}\right)_{2}\left(4,4{ }^{\prime}-\mathrm{Me}_{2} \mathrm{bpy}\right)\right]\left[\mathrm{PF}_{6}\right]$ in the active layer; $L_{\max }$ drops from 987 to $427 \mathrm{~cd} \mathrm{~m}^{-2}$ upon reducing the pulsedcurrent from 100 to $50 \mathrm{~A} \mathrm{~m}^{-2}$. An important conclusion of this investigation is that a design principle of obtaining a more blue-shifted emission by incorporating increasingly more electron-withdrawing substituents in the $\mathrm{C}^{\wedge} \mathrm{N}$ domain may not always lead to the desired results.

Table 4. Solution PL maxima $\left(\mathrm{CH}_{2} \mathrm{Cl}_{2}\right)$ for Ir-iTMCs containing the [4-CF 3 ppy]$\mathrm{C}^{\wedge} \mathrm{N}$ ligand, and EL maxima and performance data for LECs in configuration ITO/PEDOT:PSS/Ir-iTMC:[BMIM][PF 6 (4:1)/Al. The counter-ion for the Ir-iTMC was $\left[\mathrm{PF}_{6}\right]^{-}$. Data from ref. [76].

\begin{tabular}{|c|c|c|c|c|c|c|}
\hline Ir-iTMC & $\begin{array}{l}\mathrm{PL}\left(\mathrm{CH}_{2} \mathrm{Cl}_{2}\right) \\
\lambda_{\mathrm{em}}{ }^{\max } / \mathrm{nm}\end{array}$ & $\begin{array}{l}\mathrm{EL} \\
\lambda_{\mathrm{em}}{ }^{\max } / \\
\mathrm{nm}\end{array}$ & $\begin{array}{l}L_{\max ^{a}} / \\
\operatorname{cd~m}^{-1}\end{array}$ & $t_{\mathrm{on}}{ }^{\mathrm{a}, \mathrm{b}} / \min$ & $t_{\max }^{\mathrm{a}, \mathrm{c}} / \min$ & $t_{1 / 2}{ }^{\mathrm{a}, \mathrm{d}} / \min$ \\
\hline$\left[\operatorname{Ir}\left(4-\mathrm{CF}_{3} \text { ppy }\right)_{2}\left(4,4^{\prime}-\mathrm{Me}_{2} \mathrm{bpy}\right)\right]^{+}$ & 515 & 547 & $623(486)$ & $7(<1)$ & $20(29)$ & $9(321)$ \\
\hline$\left[\operatorname{Ir}\left(4-\mathrm{CF}_{3} \mathrm{ppy}\right)_{2}\left(4,4^{\prime}-\mathrm{-Bu}_{2} \mathrm{bpy}\right)\right]^{+}$ & 512 & 547 & $431(852)$ & $4(<1)$ & $10(1)$ & $12(172)$ \\
\hline$\left[\operatorname{Ir}\left(4-\mathrm{CF}_{3} \text { ppy }\right)_{2}(\text { phen })\right]^{+}$ & 520 & 555 & $512(518)$ & $11(<1)$ & $31(37)$ & $40(530)$ \\
\hline$\left[\operatorname{Ir}\left(4-\mathrm{CF}_{3} \mathrm{ppy}\right)_{2}\left(4,7-\mathrm{Me}_{2} \text { phen }\right)\right]^{+}$ & 486,501 & 551 & $283(195)$ & $15(<2)$ & $31(15)$ & $12(166)$ \\
\hline$\left[\operatorname{Ir}\left(4-\mathrm{CF}_{3} \mathrm{ppy}\right)_{2}\left(4,7-\mathrm{Ph}_{2} \text { phen }\right)\right]^{+}$ & 518 & 556 & $1094(454)$ & $17(<2)$ & $38(38)$ & $13(580)$ \\
\hline
\end{tabular}


aThe first value is for constant-voltage operation (4 V); the value in parentheses is for pulsedcurrent operation (100 A m${ }^{-2}$ per pulse). ${ }^{c} t_{\text {on }}=$ time to reach a luminance of $100 \mathrm{~cd} \mathrm{~m}^{-2} \cdot{ }^{c} t_{\max }=$ time to reach $L_{\max }{ }^{\mathrm{d}} t_{1 / 2}=$ time from $L_{\max }$ to $L_{\max } / 2$.

\subsection{Fluorine-free blue emitters: use of other substituents}

In order to circumvent possible LEC instability effects of fluorine-containing IriTMCs, it is desirable to target electroluminophores containing alternative electron-withdrawing substituents in the $\mathrm{C}^{\wedge} \mathrm{N}$ domain. Theoretical investigations have demonstrated that the use of an electron-withdrawing alkylsulfonyl group in place of fluorine is one possible strategy for blue-shifting the emission [78], and a comparison of the photophysical properties of a series of $\left[\operatorname{Ir}\left(\mathrm{C}^{\wedge} \mathrm{N}\right)_{2}(\mathrm{bpy})\right]\left[\mathrm{PF}_{6}\right]$ complexes in which the cyclometallating ligands contained fluoro, sulfane or sulfone groups confirmed that alkylsulfonate-substituted complexes were green emitters [79]. Scheme 11 shows examples of methylsulfonyl-functionalized cyclometallating ligands. One of the first studies to focus on their use involved Hmsppz which combines a $\mathrm{MeSO}_{2}$-substituted phenyl ring with an electron-rich pyrazolyl-unit, both of which lead to an increase in the HOMO-LUMO separation (see Section 6.3). LECs in configuration ITO/PEDOT:PSS/Ir-iTMC:[BMIM][PF6] (4:1)/Al containing $\left[\operatorname{Ir}(\mathrm{msppz})_{2}\left(\mathrm{~N}^{\wedge} \mathrm{N}\right)\right]\left[\mathrm{PF}_{6}\right]\left(\mathrm{N}^{\wedge} \mathrm{N}=\text { bpy, 4,4'--'Bu } 2 \text { bpy, 4,4'-(MeS) }\right)_{2}$ bpy, 6-Ph-4,4'${ }^{\mathrm{t}} \mathrm{Bu} \mathrm{z}_{2}$ bpy or 6-Ph-4-MeSbpy) were operated under a pulsed current mode leading to LEC turn-on times of the order of seconds. In solution, the complexes are green or blue-green emitters (PL $\lambda_{\mathrm{em}}{ }^{\max }$ in the range 504 to $518 \mathrm{~nm}$ ) and LECs emit green light. The LECs were characterized by high luminances (790 to 1127 $\mathrm{cd} \mathrm{m}^{-2}$ when the current density was $100 \mathrm{~A} \mathrm{~m}^{-2}$ ) but did not show long-term 
stability [78]. Short lifetimes were also found for LECs with [Ir(5-

msppy $\left.)_{2}(\mathrm{bpy})\right]\left[\mathrm{PF}_{6}\right],\left[\operatorname{Ir}\left(4-\mathrm{msppy}_{2}(\mathrm{bpy})\right]\left[\mathrm{PF}_{6}\right],\left[\operatorname{Ir}\left(3-\mathrm{msppy}_{2}(\mathrm{bpy})\right]\left[\mathrm{PF}_{6}\right],[\operatorname{Ir}(5-\right.\right.$

msppy $\left.)_{2}(\mathrm{pypz})\right]\left[\mathrm{PF}_{6}\right]$ and $\left[\operatorname{Ir}(4-\mathrm{msppy})_{2}(\mathrm{pypz})\right]\left[\mathrm{PF}_{6}\right]$ in configuration

ITO/PEDOT:PSS/Ir-iTMC:[BMIM][PF 6 (4 : 1)/Al and with a pulsed current

operating mode $[28,80]$. All are green-emitting devices. The substitution position

of the $\mathrm{MeSO}_{2}$ group in the cyclometallating ring in the $\left[\operatorname{Ir}(\mathrm{msppy})_{2}(\mathrm{bpy})\right]\left[\mathrm{PF}_{6}\right]$

has a notable affect on the value of $L_{\max }$ (4-msppy $940 \mathrm{~cd} \mathrm{~m}^{-2}, 3-\mathrm{msppy} 206 \mathrm{~cd} \mathrm{~m}^{-}$

2, 5-msppy $182 \mathrm{~cd} \mathrm{~m}^{-2}$ ). Disappointingly, in addition to having lifetimes of only a

few minutes, LECs with $\left[\operatorname{Ir}\left(5-\mathrm{msppy}_{2}(\mathrm{pypz})\right]\left[\mathrm{PF}_{6}\right]\right.$ or $\left[\operatorname{Ir}(4-\mathrm{msppy})_{2}(\mathrm{pypz})\right]\left[\mathrm{PF}_{6}\right]$

in the active layer also exhibited low luminance $\left(\leq 141 \mathrm{~cd} \mathrm{~m}^{-2}\right)[28,80]$.
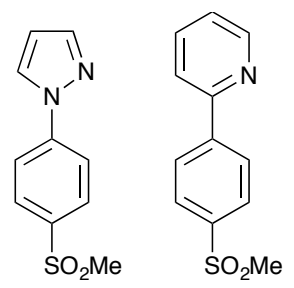

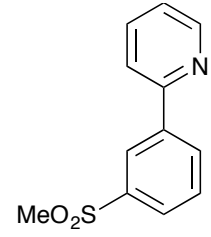

H(4-msppy)

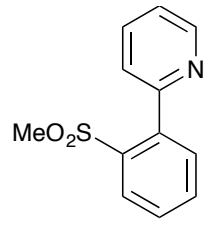

H(3-msppy)

Scheme 11. Cyclometallating ligands with electron-withdrawing methylsulfonyl substituents $(\mathrm{Hppz}=1$-phenyl-1H-pyrazole, see Section 6.3).

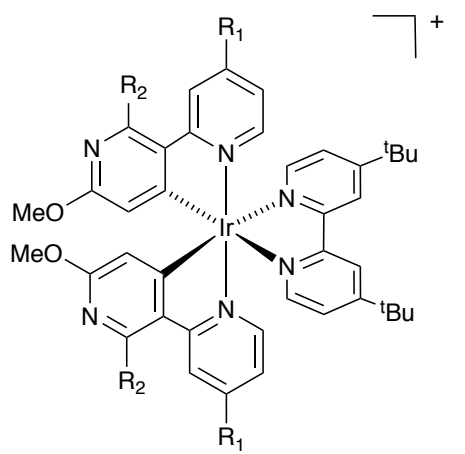

$\left[\operatorname{lr}(\text { bpy1-C })_{2}\left(4,4^{\prime}-\mathrm{Bu}_{2} \mathrm{bpy}\right)\right]^{+} \mathrm{R}_{1}=\mathrm{R}_{2}=\mathrm{Me}$

$\left[\operatorname{lr}(\text { bpy2- } C)_{2}\left(4,4^{\prime}-\mathrm{-Bu}_{2} \text { bpy }\right)\right]^{+} \quad \mathrm{R}_{1}=\mathrm{Me} ; \mathrm{R}_{2}=\mathrm{OMe}$

$\left[\operatorname{lr}(\text { bpy3-C })_{2}\left(4,4^{\prime}-\mathrm{Bu}_{2} \mathrm{bpy}\right)\right]^{+} \quad \mathrm{R}_{1}=\mathrm{H} ; \mathrm{R}_{2}=\mathrm{OMe}$

Scheme 12. Ir-iTMCs which incorporate cyclometallating ligands combining a pyridyl ring with electron-donating functionalities; all were isolated as the hexafluoridophosphate salts [81]. 
Another approach towards fluorine-free blue-green emitters uses a combination of a cyclometallating pyridyl ring with electron-donating functionalities (Scheme 12) [81]. DFT/TDDFT studies indicate that this combination is electronically similar to using the $\mathrm{H}$ (dfppy) cyclometallating ligand. In solution, the compounds shown in Scheme 12 are bright blue/green emitters (PL $\lambda_{\mathrm{em}}{ }^{\max } 510-517 \mathrm{~nm}$ ); in thin film, the maxima shift into the range $514-525 \mathrm{~nm}$. The emissions of LECs in configuration ITO/PEDOT:PSS/Ir-iTMC:[BMIM] $\left[\mathrm{PF}_{6}\right](4: 1) / \mathrm{Al}$ and operated in a pulsed current mode showed further shifting into the green region with EL $\lambda_{\mathrm{em}}{ }^{\max }=550 \mathrm{~nm}$. The devices showed extremely fast turn-on times $(<0.1 \mathrm{~s}$ to reach $\left.L=100 \mathrm{~cd} \mathrm{~m}^{-2}\right)$. The brightest LEC contained $\left[\operatorname{Ir}(\text { bpy2-C })_{2}\left(4,4{ }^{\prime}-\right.\right.$ $\left.\left.{ }^{\mathrm{t}} \mathrm{Bu}_{2} \mathrm{bpy}\right)\right]\left[\mathrm{PF}_{6}\right]$ and achieved a maximum luminance of $1054 \mathrm{~cd} \mathrm{~m}^{-2}$. Once again, however, device stability was low [81].

The number of investigations dealing with electron-withdrawing groups to replace fluorine in the $\mathrm{C}^{\wedge} \mathrm{N}$ ligands remains few. The results above show proof-of-principle for pushing the emission towards the blue, but have not yet yielded bright and stable blue-emitting LECs.

\subsection{Cyclometallating ligands with nitrogen-rich heterocycles}

Although $\left[\operatorname{Ir}(\text { ppy })_{2}(\mathrm{bpy})\right]^{+}$is the archetype Ir-iTMC, many Ir-iTMCs incorporate nitrogen-rich heterocycles in which the pyridine unit in the [ppy]- ligand is replaced by a pyrazole, triazole, tetrazole, imidazole or related unit. The effects of going from[Ir(ppy) $\left.)_{3}\right]$ to $\left[\operatorname{Ir}(\mathrm{ppz})_{3}\right](\mathrm{Hppz}$, see Scheme 13) was first described by Thompson and co-workers [82] and the ligand replacement strategy was later extended to cationic $\left[\operatorname{Ir}(\mathrm{ppz})_{2}\left(\mathrm{~N}^{\wedge} \mathrm{N}\right)\right]^{+}$species for application in LECs [83]. The triplet-state energies of [ppy ${ }^{-}$and bpy are similar [84]. In contrast, the triplet- 
state energy of $[\mathrm{ppz}]^{-}$is higher than that of bpy, and a $\left[\operatorname{Ir}(\mathrm{ppz})_{2}\left(\mathrm{~N}^{\wedge} \mathrm{N}\right)\right]^{+}$complex exhibits an emission energy that is higher than that of a corresponding $\left[\operatorname{Ir}(\mathrm{ppy})_{2}\left(\mathrm{~N}^{\wedge} \mathrm{N}\right)\right]^{+}$complex. Thus, values of $\lambda_{\mathrm{em}}{ }^{\max }$ are blue-shifted. For example, the solution PL of $\left[\operatorname{Ir}(\mathrm{ppz})_{2}(\mathrm{bpy})\right]\left[\mathrm{PF}_{6}\right]$ exhibits $\lambda_{\mathrm{em}}{ }^{\max }=563 \mathrm{~nm}$ in $\mathrm{MeCN}$ and 554 $\mathrm{nm}$ in $\mathrm{CH}_{2} \mathrm{Cl}_{2}$ [83] compared to $585 \mathrm{~nm}$ in MeCN solution [40] and $595 \mathrm{~nm}$ in $\mathrm{CH}_{2} \mathrm{Cl}_{2}[41]$ for $\left[\mathrm{Ir}(\mathrm{ppy})_{2}(\mathrm{bpy})\right]\left[\mathrm{PF}_{6}\right]$. Further blue-shifting is achieved by introducing electron-withdrawing groups (commonly fluoro) into the cyclometallating ligands, and the combination of nitrogen-rich $\mathrm{C}^{\wedge} \mathrm{N}$ ligands and fluoro-substituents is discussed in Section 6.3.

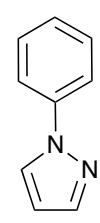

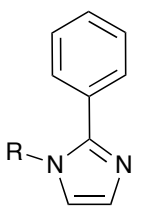

Hdphim $\mathrm{R}=\mathrm{Ph}$ Hbuphim $\mathrm{R}={ }^{\mathrm{n}} \mathrm{Bu}$
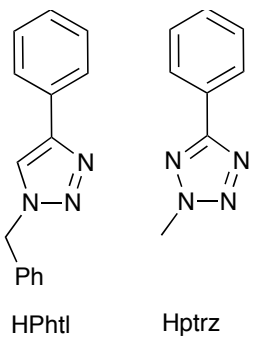

Scheme 13. Examples of ligands with nitrogen-rich cyclometallating ligands.

A series of yellow or yellow-green emitting LECs has been reported by Choe and coworkers using $\left[\operatorname{Ir}(\mathrm{ppz})_{2}(\mathrm{phen})\right]\left[\mathrm{PF}_{6}\right]$-based electroluminophores. The solution PL spectrum of $\left[\operatorname{Ir}(\mathrm{ppz})_{2}\left(4,7-\mathrm{Ph}_{2} \mathrm{phen}\right)\right]\left[\mathrm{PF}_{6}\right]$ (see Scheme 7 for 4,7$\mathrm{Ph}_{2}$ phen) has a value of $\lambda_{\mathrm{em}}{ }^{\max }=575 \mathrm{~nm}$ and a LEC shows an EL $\lambda_{\mathrm{em}}{ }^{\max }$ of $574 \mathrm{~nm}$; there is a shift to $556 \mathrm{~nm}$ when $\left[\operatorname{Ir}(\mathrm{ppz})_{2}\left(4,7-\mathrm{Ph}_{2} \mathrm{phen}\right)\right]\left[\mathrm{PF}_{6}\right]$ is blended with [EMIM][PF 6 (1:1) in a thin film [85]. These emissions are blue-shifted with respect to those with the analogous $[\mathrm{ppy}]^{-}$-containing complex (PL $\lambda_{\mathrm{em}}{ }^{\max }=605$ and EL $\lambda_{\mathrm{em}}{ }^{\max }=600 \mathrm{~nm}$ ) [61]. LECs with configuration ITO/PEDOT:PSS/IriTMC:[EMIM][PF 6$](1: 1) / \mathrm{Al}$ containing $\left[\operatorname{Ir}(\mathrm{ppz})_{2}\left(4,7-\mathrm{Ph}_{2}\right.\right.$ phen $\left.)\right]\left[\mathrm{PF}_{6}\right]$ or $\left[\operatorname{Ir}(\mathrm{ppz})_{2}\left(3,4,7,8-\mathrm{Me}_{4}\right.\right.$ phen $\left.)\right]\left[\mathrm{PF}_{6}\right]$ exhibit high luminance $\left(L_{\max }=5488\right.$ and 5236 
$\mathrm{cd} \mathrm{m}^{-2}$, respectively). These drop to 5199 and $4751 \mathrm{~cd} \mathrm{~m}^{-2}$ if no [EMIM] $\left[\mathrm{PF}_{6}\right]$ is blended with the electroluminophore [85]. On going from $\left[\operatorname{Ir}(\mathrm{ppz})_{2}(3,4,7,8\right.$ $\mathrm{Me}_{4}$ phen) $]\left[\mathrm{PF}_{6}\right]$ to $\left[\operatorname{Ir}(\mathrm{ppz})_{2}\left(5,6-\mathrm{Me}_{2} \mathrm{phen}\right)\right]\left[\mathrm{PF}_{6}\right]$ (see Scheme 7 for 5,6$\mathrm{Me}_{2}$ phen), the EL maximum shifts from 537 to $555 \mathrm{~nm}$, and from 542 to $546 \mathrm{~nm}$

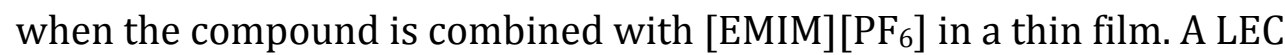
containing $\left[\operatorname{Ir}(\mathrm{ppz})_{2}\left(5,6-\mathrm{Me}_{2}\right.\right.$ phen $\left.)\right]\left[\mathrm{PF}_{6}\right]$ in a configuration ITO/PEDOT:PSS/IriTMC/Al is bright with $L_{\max }=4052 \mathrm{~cd} \mathrm{~m}^{-2}$. Choe and coworkers investigated the effects of adding different ionic liquids to the active layer and observe a decrease in $L_{\max }$ to $3850 \mathrm{~cd} \mathrm{~m}^{-2}$ for IL = [BMIM] $\left[\mathrm{PF}_{6}\right], 3300 \mathrm{~cd} \mathrm{~m}^{-2}$ for $[\mathrm{HMIM}]\left[\mathrm{PF}_{6}\right]$ and $2615 \mathrm{~cd} \mathrm{~m}^{-2}$ for $[\mathrm{EMIM}]\left[\mathrm{PF}_{6}\right][86]$. Replacing $[\mathrm{ppy}]^{-}$in $\left[\operatorname{Ir}(\mathrm{ppy})_{2}\left(\mathrm{~N}^{\wedge} \mathrm{N}\right)\right]^{+}$where $\mathrm{N}^{\wedge} \mathrm{N}=5$-methyl-1,10-phenanthroline (5-Mephen) or 2,9-di-nbutyl-1,10phenanthroline ) by [dfppy]- or [ppz]- produces the anticipated blue-shift in the PL [71,87]. LECs in configuration ITO/PEDOT:PSS/Ir-iTMC/Al incorporating $\left[\operatorname{Ir}(\mathrm{dfppy})_{2}(5-\mathrm{Mephen})\right]\left[\mathrm{PF}_{6}\right]$ or $\left[\operatorname{Ir}(\mathrm{ppz})_{2}\left(5-\mathrm{Mephen}_{[}\left[\mathrm{PF}_{6}\right]\right.\right.$ emitted green or yellow light (EL $\lambda_{\mathrm{em}}{ }^{\max }=513$ or $559 \mathrm{~nm}$ ) and achieved values of $L_{\max }=2430 \mathrm{~cd}$ $\mathrm{m}^{-2}$ (under a bias of $10 \mathrm{~V}$ ) or $1549 \mathrm{~cd} \mathrm{~m}^{-2}$ (under a bias of $9 \mathrm{~V}$ ), respectively. Under higher bias, LEC stability was low [87]. The trend for higher luminance on going from [ppz $]^{-}$to [dfppy $]^{-}$was also observed for the pair of electroluminophores $\left[\operatorname{Ir}(\mathrm{ppz})_{2}\left(2,9-{ }^{n} \mathrm{Bu}_{2}\right.\right.$ phen $\left.)\right]\left[\mathrm{PF}_{6}\right]\left(L_{\max }=773 \mathrm{~cd} \mathrm{~m}^{-2}\right.$, under a 9 V bias $)$ and $\left[\operatorname{Ir}(\mathrm{dfppy})_{2}\left(2,9-{ }^{n} \mathrm{Bu}_{2}\right.\right.$ phen $\left.)\right]\left[\mathrm{PF}_{6}\right]\left(L_{\max }=947 \mathrm{~cd} \mathrm{~m}^{-2}\right.$, under an $8.5 \mathrm{~V}$ bias). These LECs emitted green $\left(E L \lambda_{\mathrm{em}}{ }^{\max }=530 \mathrm{~nm}\right)$ and blue-green $\left(E L \lambda_{\mathrm{em}}{ }^{\text {max }}\right.$ $=502 \mathrm{~nm}$ ) light, respectively [71].

Combining the strategies of nitrogen-rich heterocyclic cyclometallating ligands and the introduction of electron-withdrawing fluoro-groups, leads to the use of H(dfppz) (Fig. 9). This cyclometallating ligand is frequently used to blue- 
shift the emissions of neutral $\left[\operatorname{Ir}\left(\mathrm{C}^{\wedge} \mathrm{N}\right)_{3}\right]$ complexes for application in OLEDs [88]. While $\left[\operatorname{Ir}(\mathrm{ppy})_{2}(\mathrm{Phbpy})\right]\left[\mathrm{PF}_{6}\right]$ is an orange emitter with a PL $\lambda_{\mathrm{em}}{ }^{\max }=595 \mathrm{~nm}$ (see Section 4), [Ir(dfppz) $\left.)_{2}(\mathrm{Phbpy})\right]\left[\mathrm{PF}_{6}\right]$ exhibits an emission maximum at 517 $\mathrm{nm}(\mathrm{MeCN}$ solution). Functionalization of the bpy domain with electron-donating $\mathrm{NMe}_{2}$ groups (see Section 6.4) results in a further shift in PL towards the blue, viz. $505 \mathrm{~nm}$ for $\left[\operatorname{Ir}(\mathrm{dfppz})_{2}\left(4-\mathrm{Me}_{2} \mathrm{~N}-\mathrm{Phbpy}\right)\right]\left[\mathrm{PF}_{6}\right]$ and $501 \mathrm{~nm}$ for $\left[\operatorname{Ir}(\mathrm{dfppz})_{2}\left(4,4^{\prime}-\left(\mathrm{Me}_{2} \mathrm{~N}\right)_{2}-\mathrm{Phbpy}\right)\right]\left[\mathrm{PF}_{6}\right]\left(4-\mathrm{Me}_{2} \mathrm{~N}-\mathrm{Phbpy}=4-(\mathrm{N}, \mathrm{N}-\right.$ dimethylamino)-6-phenyl-2,2'-bipyridine, 4-( $\left.\mathrm{Me}_{2} \mathrm{~N}\right)_{2}$-Phbpy = 4,4'-bis $(N, N$ dimethylamino)-6-phenyl-2,2'-bipyridine). The design principle of these Phbpybased complexes includes a $\pi$-stacking interaction (Section 4) between phenyl and difluorophenyl rings to enhance LEC stability (Fig. 9a). LECs in configuration ITO/PEDOT:PSS/Ir-iTMC:[BMIM][PF6] (4:1)/Al and operated under pulsed current driving, reached values of $L_{\max }=52,572$ and $205 \mathrm{~cd} \mathrm{~m}^{-2}$ for ancillary ligands Phbpy, 4-Me ${ }_{2} \mathrm{~N}-\mathrm{Phbpy}$ and 4,4'-( $\left.\mathrm{Me}_{2} \mathrm{~N}\right)_{2}$-Phbpy, respectively. Red-shifting on going from solution PL to device EL resulted in EL maxima of 545, 550 and $574 \mathrm{~nm}$, respectively, and thus the LECs emit green rather than blue light [89]. The complex cations $\left[\operatorname{Ir}(\mathrm{dfppz})_{2}(\mathrm{sp})\right]^{+},\left[\operatorname{Ir}(\mathrm{dfppz})_{2}(\mathrm{Phsp})\right]^{+}$and $\left[\operatorname{Ir}(\mathrm{dfppz})_{2}\left(\mathrm{Ph}_{2} \mathrm{sp}\right)\right]^{+}$(see Fig. 9 for ligand structures) were designed to include a bulky peripheral functionality in the bpy ligand (see Section 5) and represent a series in which there is no, one or two phenyl and difluorophenyl ring $\pi$-stacking interactions [54]. Figure 9b shows the two stacking contacts in $\left[\operatorname{Ir}(\mathrm{dfppz})_{2}\left(\mathrm{Ph}_{2} \mathrm{sp}\right)\right]^{+}$. Blue emissions are exhibited by $\mathrm{CH}_{2} \mathrm{Cl}_{2}$ solutions of $\left[\operatorname{Ir}(\mathrm{dfppz})_{2}(\mathrm{sp})\right]\left[\mathrm{PF}_{6}\right]\left(\mathrm{PL} \lambda_{\mathrm{em}}{ }^{\max }=500 \mathrm{~nm}\right),\left[\operatorname{Ir}(\mathrm{dfppz})_{2}(\mathrm{Phsp})\right]\left[\mathrm{PF}_{6}\right](504 \mathrm{~nm})$ and $\left[\operatorname{Ir}(\mathrm{dfppz})_{2}\left(\mathrm{Ph}_{2} \mathrm{Sp}\right)\right]\left[\mathrm{PF}_{6}\right](505 \mathrm{~nm})$ with PLQY in the range 38-47\%. LECs in configuration ITO/PEDOT:PSS/Ir-iTMC:[BMIM][PF 6$]$ (20wt \% IL)/Al and under a 
3.4 V bias reached $L_{\max }=25.5,5.76$ and $10.6 \mathrm{~cd} \mathrm{~m}^{-2}$ in 54, 390 and $96 \mathrm{~min}$, respectively, but values of the EL maxima are not reported. The longest-lived LEC of the series is that with $\left[\operatorname{Ir}(\mathrm{dfppz})_{2}(\mathrm{Phsp})\right]\left[\mathrm{PF}_{6}\right](585 \mathrm{~min})$, but this is at the expense of a long turn-on time.

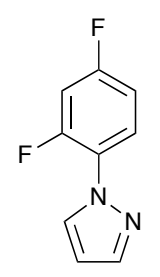

$\mathrm{H}(\mathrm{dfppz})$

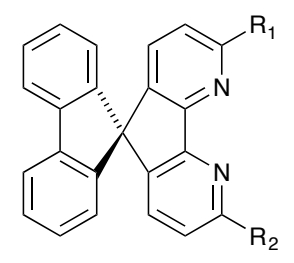
$\begin{array}{ll}\mathrm{sp} & \mathrm{R} 1=\mathrm{R}_{2}=\mathrm{H} \\ \mathrm{Phsp} & \mathrm{R}_{1}=\mathrm{H}, \mathrm{R}_{2}=\mathrm{Ph} \\ \mathrm{Ph}_{2} \mathrm{sp} & \mathrm{R}_{1}=\mathrm{R}_{2}=\mathrm{Ph}\end{array}$

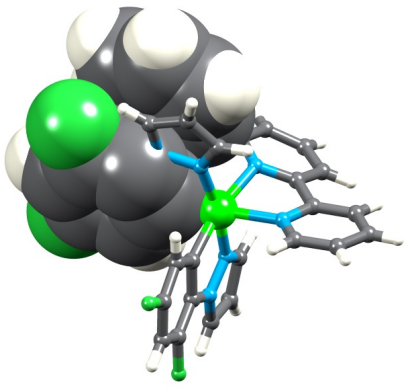

(a)

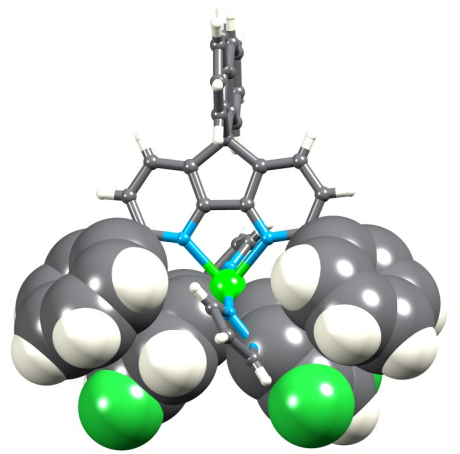

(b)

Fig. 9. Structures of $\mathrm{H}(\mathrm{dfppz})$ and the ancillary ligands sp, Phsp and $\mathrm{Ph}_{2} \mathrm{sp}$. The crystallographically determined structures of (a) [Ir(dfppz) $\left.)_{2}(\mathrm{Phbpy})\right]^{+}$in the $\left[\mathrm{PF}_{6}\right]^{-}$salt (CSD refcode TEPSAK [89]) and (b) $\left[\operatorname{Ir}(\mathrm{dfppz})_{2}\left(\mathrm{Ph}_{2} \mathrm{sp}\right)\right]^{+}$in the $\left[\mathrm{PF}_{6}\right]^{-}$ salt (CSD refcode GEMXED [54]).

Phenylimidazoles exhibit high triplet-energy levels, and have been shown to lead to greenish-blue and blue phosphorescent iridium(III) complexes $[90,91,92]$. However, only a few cationic Ir-iTMCs containing phenylimidazoles as the cyclometallating ligands have been reported. He et al. have described the syntheses, photophysical properties and performances in LECs of $\left[\operatorname{Ir}(\text { dphim })_{2}(\mathrm{bpy})\right]\left[\mathrm{PF}_{6}\right],\left[\operatorname{Ir}(\mathrm{dphim})_{2}(\mathrm{pzpy})\right]\left[\mathrm{PF}_{6}\right]$ and $\left[\operatorname{Ir}(\text { buphim })_{2}(\mathrm{pzpy})\right]\left[\mathrm{PF}_{6}\right]$ (pzpy = 2-(1H-pyrazol-1-yl)pyridine; Hdphim and Hbuphim are shown in Scheme 13) [93]. In solution, $\left[\operatorname{Ir}(\mathrm{dphim})_{2}(\mathrm{bpy})\right]\left[\mathrm{PF}_{6}\right]$ is an orange-red emitter $\left(\mathrm{PL} \lambda_{\mathrm{em}}{ }^{\mathrm{max}}=591 \mathrm{~nm}\right.$ and PLQY $\left.=13 \%\right)$. The effect of replacing the bpy ligand by the nitrogen-rich pzpy ligand (see Section 6.4) to give $\left[\operatorname{Ir}(\mathrm{dphim})_{2}(\mathrm{pzpy})\right]\left[\mathrm{PF}_{6}\right]$ is to blue-shift the solution emission to $500 \mathrm{~nm}$. Similarly, 
$\left[\operatorname{Ir}(\text { buphim })_{2}(\right.$ pzpy) $]\left[\mathrm{PF}_{6}\right]$ exhibits a green-blue emission $\left(\mathrm{PL} \lambda_{\mathrm{em}}{ }^{\max }=510 \mathrm{~nm}\right)$. LECs with configuration ITO/PEDOT:PSS/Ir-iTMC/Al were operated under constant bias. With $\left[\operatorname{Ir}(\mathrm{dphim})_{2}(\mathrm{bpy})\right]\left[\mathrm{PF}_{6}\right]$ in the active layer, a LEC reached $L_{\max }$ $=50.3 \mathrm{~cd} \mathrm{~m}^{-2}$ in $285 \mathrm{~min}$ when driven at $2.5 \mathrm{~V}$, and $354 \mathrm{~cd} \mathrm{~m}^{-2}$ in $16.5 \mathrm{~min}$ under a $3.0 \mathrm{~V}$ bias. The EL $\lambda_{\mathrm{em}}{ }^{\text {max }}$ of $578 \mathrm{~nm}$ is blue-shifted with respect to solution (591 $\mathrm{nm})$; values of EL $\lambda_{\mathrm{em}}{ }^{\max }=508$ or $509 \mathrm{~nm}$ for LECs containing $\left[\operatorname{Ir}(\text { dphim })_{2}(\right.$ pzpy) $]\left[\mathrm{PF}_{6}\right]$ or $\left[\operatorname{Ir}(\text { buphim })_{2}(\right.$ pzpy $\left.)\right]\left[\mathrm{PF}_{6}\right]$ compare with solution PL maxima of 500 or $510 \mathrm{~nm}$. Compared to the LEC containing $\left[\operatorname{Ir}(\text { dphim })_{2}(\mathrm{bpy})\right]\left[\mathrm{PF}_{6}\right]$, those with $\left[\operatorname{Ir}(\mathrm{dphim})_{2}(\mathrm{pzpy})\right]\left[\mathrm{PF}_{6}\right]$ or $\left[\operatorname{Ir}(\text { buphim })_{2}(\right.$ pzpy) $]\left[\mathrm{PF}_{6}\right]$ required a higher bias $(4.0 \mathrm{~V})$ to turn on and reached lower maximum luminances [93].

Triazole-based cyclometallating ligands are readily prepared using Click chemistry $[94,95]$. This synthetic methodology gives a convenient means of introducing different functionalities, thereby tuning the emission colour of IriTMCs containing triazole-based $\mathrm{C}^{\wedge} \mathrm{N}$ ligands. Zysman-Colman and coworkers [96] have demonstrated PL emission colours ranging from yellow to sky-blue in a series of $\left[\operatorname{Ir}\left(\mathrm{C}^{\wedge} \mathrm{N}\right)_{2}\left(\mathrm{~N}^{\wedge} \mathrm{N}\right)\right]\left[\mathrm{PF}_{6}\right]$ complexes in which $\mathrm{H}\left(\mathrm{C}^{\wedge} \mathrm{N}\right)$ is $\mathrm{H}(\mathrm{Phtl})$ (Scheme 13) or a difluoro-derivative (see Section 6.1 ) and the $N^{\wedge} N$ ligand is bpy or $4,4^{\prime}-$ ${ }^{t} \mathrm{Bu}_{2}$ bpy. The benzyl group in $\mathrm{H}(\mathrm{Phtl})$ (Scheme 13) was selected to protect the iridium(III) centre (Fig. 10) [96,97], and has been similarly employed by the DeCola group $[98,99]$. Solution PL spectra of $\left[\operatorname{Ir}(\mathrm{Phtl})_{2}(\mathrm{bpy})\right]\left[\mathrm{PF}_{6}\right]$ (and $\left[\operatorname{Ir}(\mathrm{Phtl})_{2}\left(4,4^{\prime}-\mathrm{Bu}_{2} \mathrm{bpy}\right)\right]\left[\mathrm{PF}_{6}\right]$ are blue-shifted with respect to those of $\left[\operatorname{Ir}(\mathrm{ppy})_{2}(\mathrm{bpy})\right]\left[\mathrm{PF}_{6}\right]\left(\lambda_{\mathrm{em}}{ }^{\max }=585 \mathrm{~nm}\right.$ in $\mathrm{MeCN}$ solution [40], $595 \mathrm{~nm}$ in $\mathrm{CH}_{2} \mathrm{Cl}_{2}$ [41]) and $\left[\operatorname{Ir}(\mathrm{ppy})_{2}\left(4,4^{\prime}-{ }^{\mathrm{t}} \mathrm{Bu}_{2} \mathrm{bpy}\right)\right]\left[\mathrm{PF}_{6}\right]$, and PLQY values increase. However, replacing the $[\mathrm{ppz}]^{-}$cyclometallating ligand in $\left[\operatorname{Ir}(\mathrm{ppz})_{2}(\mathrm{bpy})\right]\left[\mathrm{PF}_{6}\right]\left(\mathrm{PL} \lambda_{\mathrm{em}}{ }^{\max }=\right.$ 
$563 \mathrm{~nm}$ in $\mathrm{MeCN}, 554 \mathrm{~nm}$ in $\mathrm{CH}_{2} \mathrm{Cl}_{2}$ ) [83] by [Phtl]- in [Ir(Phtl) $\left.)_{2}(\mathrm{bpy})\right]\left[\mathrm{PF}_{6}\right](\mathrm{PL}$ $\lambda_{\mathrm{em}}{ }^{\max }=580 \mathrm{~nm}$ in MeCN) [96] is not accompanied by a blue-shift in PL. Further tuning of the emission colour by introducing fluoro-substituents into triazolebased cyclometallating ligands is detailed in Section 6.4 .

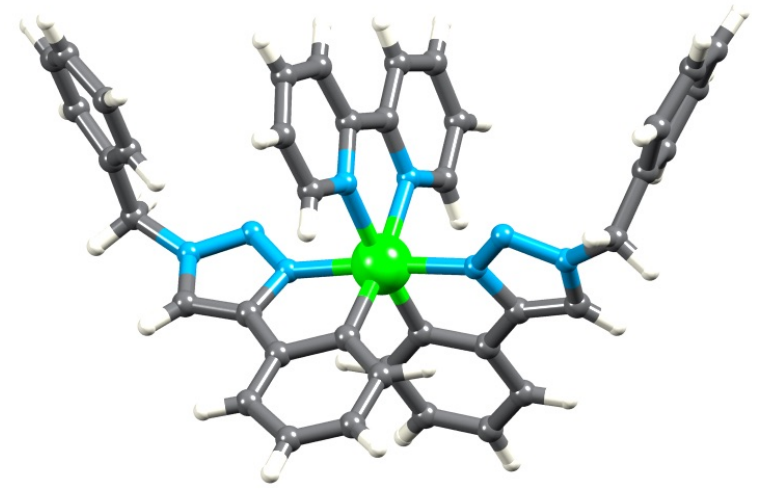

Fig. 10. The structure of the $\left[\operatorname{Ir}(\mathrm{Phtl})_{2}(\mathrm{bpy})\right]^{+}$cation in $\left[\operatorname{Ir}(\mathrm{Phtl})_{2}(\mathrm{bpy})\right]\left[\mathrm{PF}_{6}\right]$ showing the protecting influence of the benzyl substituents in the $\mathrm{C}^{\wedge} \mathrm{N}$ ligands (CSD refcode RAPYAK) [96].

A move from triazole to tetrazole-containing cyclometallated ligands encountered a problem in that the reaction between $\operatorname{IrCl}_{3} \cdot x \mathrm{H}_{2} \mathrm{O}$ with $\mathrm{Hprtz}$ (Scheme 13) did not produce the anticipated $\left[\operatorname{Ir}_{2}(\mathrm{prtz})_{4} \mathrm{Cl}_{2}\right]$ dimer. However, use of a solvento approach (see Section 2) gave $\left[\operatorname{Ir}(\mathrm{prtz})_{2}(\mathrm{NCMe})_{2}\right]\left[\mathrm{BF}_{4}\right]$ which subsequently reacted with bpy, phen or $4,4^{\prime}-{ }^{-} \mathrm{Bu}_{2}$ bpy to yield the corresponding $\left[\operatorname{Ir}(p r t z)_{2}\left(\mathrm{~N}^{\wedge} \mathrm{N}\right)\right]\left[\mathrm{BF}_{4}\right]$ salts [38]. The incorporation of the tetrazole-containing $\mathrm{C}^{\wedge} \mathrm{N}$ ligand shifts the emission of the $\left[\operatorname{Ir}\left(\mathrm{C}^{\wedge} \mathrm{N}\right)_{2}\left(\mathrm{~N}^{\wedge} \mathrm{N}\right)\right]^{+}$complex further to the blue with respect to pyrazole or triazole-containing analogues. In solution, $\left[\operatorname{Ir}(\text { prtz })_{2}(\mathrm{bpy})\right][\mathrm{BF} 4],\left[\operatorname{Ir}(\text { prtz })_{2}(\right.$ phen $\left.)\right]\left[\mathrm{BF}_{4}\right]$ and $\left[\operatorname{Ir}(\text { prtz })_{2}\left(4,4^{\prime}-{ }^{-} \mathrm{Bu}_{2} \mathrm{bpy}\right)\right]\left[\mathrm{BF}_{4}\right]$ are blue-green emitters (PL $\lambda_{\mathrm{em}}{ }^{\max } \sim 540 \mathrm{~nm}$ ) with high PLQYs (55-70\%). Neat thin films of the complexes had emission maxima in the range $520-535 \mathrm{~nm}$; thin films in a PMMA matrix were blue-shifted by $30-40 \mathrm{~nm}$ with respect to the neat 
films. The best performing Ir-iTMC of the series was $\left[\operatorname{Ir}(\operatorname{prtz})_{2}\left(4,4^{\prime}-\right.\right.$

$\left.\left.{ }^{\mathrm{t}} \mathrm{Bu}_{2} \mathrm{bpy}\right)\right]\left[\mathrm{BF}_{4}\right]$ and LECs with this salt in the active layer (blended with

$[\mathrm{BMIM}]\left[\mathrm{PF}_{6}\right]$ in an Ir-iTMC:IL ratio $=4: 1$ ) reached a value of $L_{\max }=310 \mathrm{~cd} \mathrm{~m}^{-2}$. Although this is particularly high for a blue-emitting device, the LEC was of limited stability with the luminance dropping to $20 \mathrm{~cd} \mathrm{~m}^{-2}$ after 2 hours. This short lifetime was rationalized in terms of unbalanced charge transport within the LEC [38].

\section{4 $\mathrm{N}^{\wedge} \mathrm{N}$ ligands with electron-donating substituents or nitrogen-rich}

\section{heterocycles}

In contrast to the orange-emitting $\left[\operatorname{Ir}(\mathrm{ppy})_{2}(\mathrm{bpy})\right]\left[\mathrm{PF}_{6}\right]\left(\lambda_{\mathrm{em}}{ }^{\max }=585 \mathrm{~nm}\right.$ in MeCN solution [40], $595 \mathrm{~nm}$ in $\mathrm{CH}_{2} \mathrm{Cl}_{2}$ [41]), [ $\left.\operatorname{Ir}(\mathrm{ppy})_{2}\left(4,4{ }^{\prime}-\left(\mathrm{Me}_{2} \mathrm{~N}\right)_{2} \mathrm{bpy}\right)\right]\left[\mathrm{PF}_{6}\right]$ with strongly electron-donating $N, N$-dimethylamino substituents in the $\mathrm{N}^{\wedge} \mathrm{N}$ ligand is a blue-green emitter [100]. The blue-shift in PL on going to $\left[\operatorname{Ir}(\text { ppy })_{2}\left(4,4^{\prime}-\left(\mathrm{Me}_{2} \mathrm{~N}\right)_{2} \mathrm{bpy}\right)\right]\left[\mathrm{PF}_{6}\right]\left(\lambda_{\mathrm{em}}{ }^{\max }=520 \mathrm{~nm}\right.$ with shoulder at $\left.491 \mathrm{~nm}\right)$ is due to the destabilization of the LUMO which is localized on the $\mathrm{N}^{\wedge} \mathrm{N}$ ligand (Fig. 2). This example demonstrates a general strategy of incorporating electrondonating groups into the $\mathrm{N}^{\wedge} \mathrm{N}$ domain. The $520 \mathrm{~nm}$ emission of $\left[\operatorname{Ir}(\mathrm{ppy})_{2}\left(4,4^{\prime}-\right.\right.$ $\left.\left.\left(\mathrm{Me}_{2} \mathrm{~N}\right)_{2} \mathrm{bpy}\right)\right]\left[\mathrm{PF}_{6}\right]$ shifts to higher energy $493 \mathrm{~nm}$ when [ppy]- is replaced by [dfppz]- giving a blue-emission in solution [89]. However, this does not carry through to the EL of a LEC with $\left[\operatorname{Ir}(\mathrm{ppy})_{2}\left(4,4^{\prime}-\left(\mathrm{Me}_{2} \mathrm{~N}\right)_{2} \mathrm{bpy}\right)\right]\left[\mathrm{PF}_{6}\right]$ in the active layer $\left(E L \lambda_{\mathrm{em}}{ }^{\max }=551 \mathrm{~nm}\right)$. A LEC in configuration ITO/PEDOT:PSS/IriTMC:[BMIM] [PF $]$ (4:1)/Al has a fast turn-on $\left(t_{\text {on }}<5 \mathrm{~s}\right)$ but is not bright $\left(L_{\max }=\right.$ $\left.67 \mathrm{~cd} \mathrm{~m}^{-2}\right)$ nor stable $\left(t_{1 / 2}=0.01 \mathrm{~h}\right)$. This poor performance is attributed to possible protonation of the amino-groups [89]. 


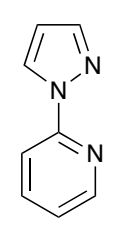

pzpy
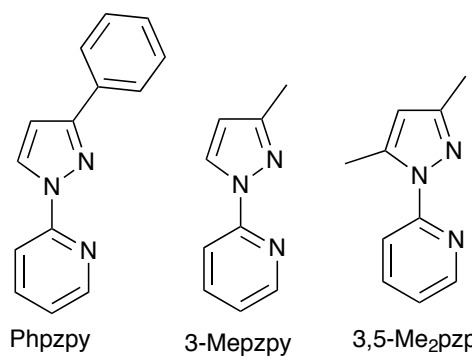

3,5-Me ${ }_{2}$ pzpy

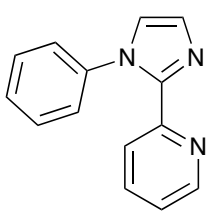

pyim

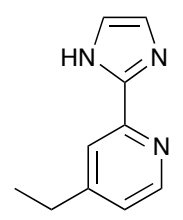

EPimid

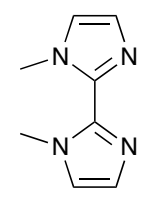

bid

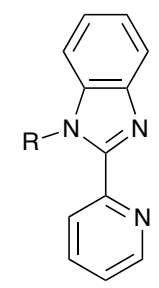

Phpybi $\mathrm{R}=\mathrm{Ph}$ Mepybi $\mathrm{R}=\mathrm{Me}$ Etpybi $\quad R=E t$ Octpybi $R={ }^{n}$ octyl<smiles>c1ccc(-n2c(-c3ccc4ccccc4n3)nc3ccccc32)cc1</smiles><smiles>Pn1cc(-c2ccccn2)nn1</smiles>

qlbi

$$
\begin{aligned}
& \text { pytriaz-R } \\
& \mathrm{R}= \\
& \begin{array}{l}
\text { benzyl } \\
\text { phenyl } \\
\text { biphenyl } \\
\text { adamantyl }
\end{array}
\end{aligned}
$$

Scheme 14. Examples of $\mathrm{N}^{\wedge} \mathrm{N}$ ligands with nitrogen-rich heterocycles.

Scheme 14 gives the structures of a range of $\mathrm{N}^{\wedge} \mathrm{N}$ ligands which incorporate one or two nitrogen-rich heterocycles. Compared to the archetype $\left[\operatorname{Ir}(\mathrm{ppy})_{2}(\mathrm{bpy})\right]^{+}$, replacing one or both pyridine rings by heterocycles such as pyrazine, imidazole, triazine or tetrazine, leads to an increase in the HOMO-LUMO gap and a blueshift in the emission of the Ir-iTMC. This was initially shown by Qiu and coworkers [101] who compared the emission of $\left[\operatorname{Ir}(\mathrm{ppy})_{2}(\mathrm{pzpy})\right]\left[\mathrm{PF}_{6}\right](\mathrm{MeCN}$ solution PL $\left.\lambda_{\mathrm{em}}{ }^{\max }=475 \mathrm{~nm}\right)$ with that of $\left[\operatorname{Ir}(\mathrm{ppy})_{2}(\mathrm{bpy})\right]\left[\mathrm{PF}_{6}\right]\left(\mathrm{PL} \lambda_{\mathrm{em}}{ }^{\max }=585\right.$ nm in MeCN [40]). A LEC device in configuration ITO/PEDOT:PSS/Ir-iTMC/Al 
with $\left[\operatorname{Ir}(\mathrm{ppy})_{2}(\mathrm{pzpy})\right]\left[\mathrm{PF}_{6}\right]$ in the active layer exhibits a blue-green emission (EL $\left.\lambda_{\mathrm{em}}{ }^{\max }=486 \mathrm{~nm}\right)$. The value of $L_{\max }=52 \mathrm{~cd} \mathrm{~m}^{-2}$ increased to $94 \mathrm{~cd} \mathrm{~m}^{-2}$ by using an $\sim 3: 1$ blend of $\left[\operatorname{Ir}(\mathrm{ppy})_{2}(\mathrm{pzpy})\right]\left[\mathrm{PF}_{6}\right]$ and $[\mathrm{BMIM}]\left[\mathrm{PF}_{6}\right]$. When reported in 2008 , the LEC efficiency of $4.3 \mathrm{~cd} \mathrm{~A}^{-1}$ was one of the highest for a blue-green LEC [101]. Interestingly, salts of $\left[\operatorname{Ir}(\mathrm{ppy})_{2}(\mathrm{pzpy})\right]^{+}$have also been employed in the active layers of simple-architecture, solution-processed OLEDs. By doping at low concentrations ( 2 or $3 \mathrm{wt} \%$ ) and controlling anion migration, Duan and cowrokers achieved efficient blue-green OLEDs, the highest value of $L_{\max }$ being $14200 \mathrm{~cd} \mathrm{~m}^{-2}\left[{ }^{16}\right]$. The LEC EL maximum of $486 \mathrm{~nm}$ for $\left[\operatorname{Ir}(\mathrm{ppy})_{2}(\mathrm{pzpy})\right]\left[\mathrm{PF}_{6}\right] \mathrm{can}$ be further blue-shifted to $460 \mathrm{~nm}$ by combining the strategies of using the nitrogen-rich pzpy with the presence of electron-withdrawing fluoro-groups in the $C^{\wedge} N$ domains (see Section 6.3) [101]. The short LEC lifetime of 32 min was extended to $218 \mathrm{~min}$ by replacing the [ppy]- ligands in $\left[\operatorname{Ir}(\mathrm{ppy})_{2}(\mathrm{pzpy})\right]\left[\mathrm{PF}_{6}\right]$ by [ppz]- (Hppz, Scheme 13) [102]. This example illustrates the advantages of incorporating nitrogen-rich heterocycles into both the $\mathrm{C}^{\wedge} \mathrm{N}$ and $\mathrm{N}^{\wedge} \mathrm{N}$ domains. In contrast to the blue-green LEC emission of $\left[\operatorname{Ir}(\mathrm{ppy})_{2}(\mathrm{pzpy})\right]\left[\mathrm{PF}_{6}\right], \mathrm{LECs}$ containing $\left[\operatorname{Ir}(\mathrm{ppy})_{2}(3-\mathrm{Mepzpy})\right]\left[\mathrm{PF}_{6}\right]$ or $\left[\operatorname{Ir}(\mathrm{ppy})_{2}\left(3,5-\mathrm{Me}_{2} \mathrm{pzpy}\right)\right]\left[\mathrm{PF}_{6}\right]$ (see Scheme 14) emit yellow light (EL $\lambda_{\mathrm{em}}{ }^{\max }=537$ or $\left.543 \mathrm{~nm}\right)$; the LECs in this case contained no ionic liquid (configuration ITO/PEDOT:PSS/Ir-iTMC/Al). The EL values of 537 or $543 \mathrm{~nm}$ were red-shifted with respect to the MeCN solution PL $\left(\lambda_{\mathrm{em}}{ }^{\max }=478\right.$ and $476 \mathrm{~nm}$, respectively). A blue-shift in the EL to 503 or $511 \mathrm{~nm}$ was induced by using the difluoro-substituted $\mathrm{C}^{\wedge} \mathrm{N}$ ligand $[\mathrm{dfppy}]^{-}$(see Section 6.3) and the luminance was also enhanced. LECs containing $\left[\operatorname{Ir}(p p y)_{2}(3-\right.$ Mepzpy)][PF 6 or $\left[\operatorname{Ir}(\mathrm{ppy})_{2}\left(3,5-\mathrm{Me}_{2} \mathrm{pzpy}\right)\right]\left[\mathrm{PF}_{6}\right]$ have $L_{\max }=351$ and $549 \mathrm{~cd} \mathrm{~m}^{-2}$, respectively, compared to 560 or $658 \mathrm{~cd} \mathrm{~m}^{-2}$ for LECs with [Ir(dfppy) $)_{2}$ (3- 
Mepzpy)][PF 6 or [Ir(dfppy) 2 (3,5-Me 2 pzpy)][PF 6 [103]. On going from

$\left[\operatorname{Ir}(\mathrm{ppy})_{2}(3-\mathrm{Mepzpy})\right]\left[\mathrm{PF}_{6}\right]$ or $\left[\operatorname{Ir}(\mathrm{ppy})_{2}\left(3,5-\mathrm{Me}_{2} \mathrm{pzpy}\right)\right]\left[\mathrm{PF}_{6}\right]$ to

$\left[\operatorname{Ir}(\text { ppy })_{2}(\mathrm{Phpzpy})\right]\left[\mathrm{PF}_{6}\right]$, the luminance is significantly improved $\left(L_{\max }=1246 \mathrm{~cd}\right.$ $\mathrm{m}^{-2}$ ); the EL showed a structured emission with maxima at 480 and $516 \mathrm{~nm}$ [104]. Although not discussed by the authors (despite a DFT-optimized structure) [104], the introduction of a pendant phenyl group into the Phpzpy ligand should lead to an intra-cation $\pi$-stacking contact as in the related complex [Ir(dmppz) $\left.)_{2}(\mathrm{Phbpy})\right]\left[\mathrm{PF}_{6}\right]$ (Fig. 11) [51]. Duan and Qiu demonstrated that the intra-cation $\pi$-stacking contact in $\left[\operatorname{Ir}(\mathrm{ppy})_{2}(\mathrm{Phpz} 3 p y)\right]\left[\mathrm{PF}_{6}\right]$ (see Fig. 12 for Phpz3py) resulted in dramatically improved LEC stability when compared to the performance of a LEC containing $\left[\operatorname{Ir}(\mathrm{ppy})_{2}(\mathrm{pzpy})\right]\left[\mathrm{PF}_{6}\right]$ in the active layer [53]. Note that pz3py $=2-(1 H-$ pyrazol-3-yl $)$ pyridine while pzpy $=2-(1 H-$ pyrazol-1-

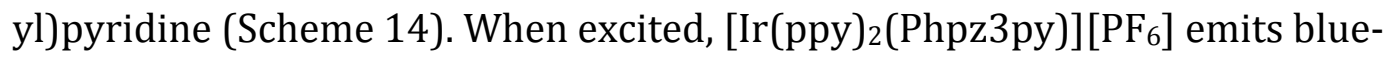
green light in solution, exhibiting a structured emission spectrum (see Section 1) with maxima at 480 and $509 \mathrm{~nm}$. LECs in configuration ITO/PEDOT:PSS/IriTMC:[BMIM] $\left[\mathrm{PF}_{6}\right](2: 1) / \mathrm{Al}$ with $\left[\operatorname{Ir}(\mathrm{ppy})_{2}(\mathrm{pzpy})\right]\left[\mathrm{PF}_{6}\right]$ or $\left[\operatorname{Ir}(\mathrm{ppy})_{2}(\mathrm{Phpz} 3 \mathrm{py})\right]\left[\mathrm{PF}_{6}\right]$ in the active layer were blue-green emitters. Under a constant $3 \mathrm{~V}$ bias, the LEC with $\left[\operatorname{Ir}(\mathrm{ppy})_{2}(\mathrm{pzpy})\right]\left[\mathrm{PF}_{6}\right]$ reached $L_{\max }=1.4 \mathrm{~cd} \mathrm{~m}^{-2}$ in $3.8 \mathrm{~min}$ and had a lifetime of $300 \mathrm{~min}$. In contrast, under the same operating conditions, a LEC with $\left[\operatorname{Ir}(\mathrm{ppy})_{2}(\mathrm{Phpz} 3 \mathrm{py})\right]\left[\mathrm{PF}_{6}\right]$, reached $L_{\max }=37 \mathrm{~cd} \mathrm{~m}^{-2}$ in 325 $\min$ and had a value of $t_{1 / 2}=950 \mathrm{~min}$. Although the luminance and lifetime were deemed relatively low compared to typical orange emitters (in 2012), the design principles applied in this investigation [53] were promising. Duan and Qiu extended the investigation to a structural comparison of $\left[\operatorname{Ir}(\mathrm{ppy})_{2}(\mathrm{Phpz} 3 \mathrm{py})\right]\left[\mathrm{PF}_{6}\right],\left[\operatorname{Ir}(\mathrm{ppy})_{2}(\mathrm{~F} 2 \mathrm{Phpz} 3 \mathrm{py})\right]\left[\mathrm{PF}_{6}\right]$ and 
[Ir(ppy) $)_{2}$ (F5Phpz3py)][PF 6 (Fig. 12) [105]. Crystallographic data for the three complexes confirmed $\pi$-stacking between the pendant phenyl or fluorinated phenyl ring and one of the cyclometallated rings (Fig. 12). On going from $\left[\operatorname{Ir}(\mathrm{ppy})_{2}(\mathrm{Phpz} 3 \mathrm{py})\right]\left[\mathrm{PF}_{6}\right]$ to $\left[\operatorname{Ir}(\mathrm{ppy})_{2}(\mathrm{~F} 2 \mathrm{Phpz} 3 \mathrm{py})\right]\left[\mathrm{PF}_{6}\right]$ to $\left[\operatorname{Ir}(\mathrm{ppy})_{2}(\mathrm{~F} 5 \mathrm{Phpz} 3 \mathrm{py})\right]\left[\mathrm{PF}_{6}\right]$, the angle between the planes of the stacked rings decreases ( 21 to 18 to $5.0^{\circ}$ ) and the centroid-to-centroid separation decreases (3.75 to 3.65 to $3.52 \AA$ ), indicating increasingly efficient face-to-face contacts. In solution, all three complexes show similar structured emission spectra (see Section 1) with maxima at 480 and $509 \mathrm{~nm}, 480$ and $507 \mathrm{~nm}$, and 476 and 506 $\mathrm{nm}$, respectively, and these change little on going to a thin film. An evaluation of the two fluorinated complexes in LECs has not yet been reported.

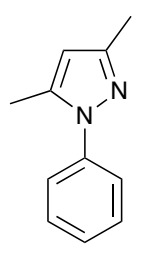

Hdmppz

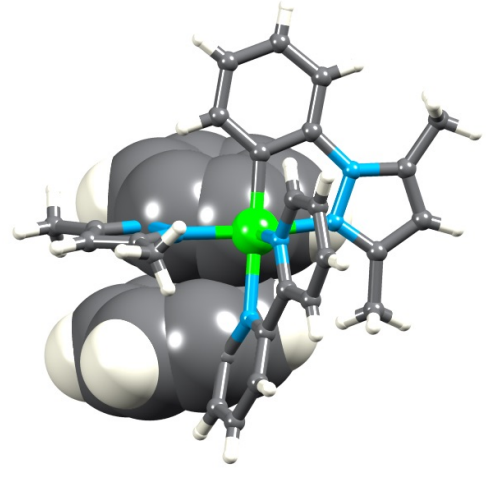

Fig. 11. The structure of the cyclometallating ligand Hdmppz and the structure of the cation in $\left[\operatorname{Ir}(\mathrm{dmppz})_{2}(\mathrm{Phbpy})\right]\left[\mathrm{PF}_{6}\right]$ showing the $\pi$-stacking interaction within the iridium coordination sphere (CSD refcode YUWWOD) [51]. 


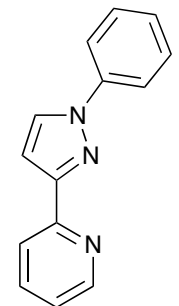

Phpz3py

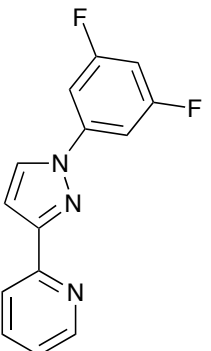

F2Phpz3py

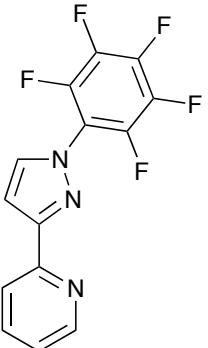

F5Phpz3py

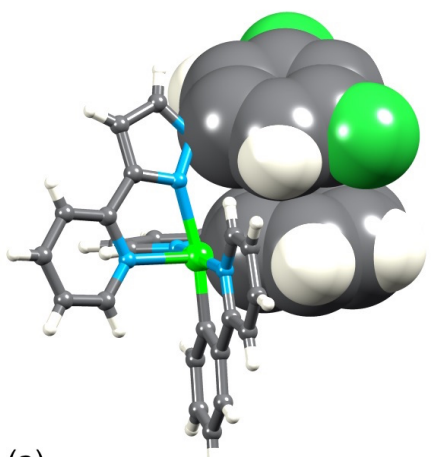

(a)

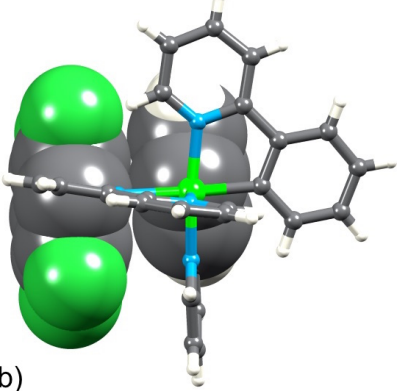

(b)

Fig. 12. Structures of the $\mathrm{N}^{\wedge} \mathrm{N}$ ligands Phpz3py, F2Phpz3py and F5Phpz3py, and crystallographically determined structures of the cations in (a) [Ir(ppy) $\left.)_{2}(\mathrm{~F} 2 \mathrm{Phpz} 3 p y)\right]\left[\mathrm{PF}_{6}\right]$ and (b) $\left[\operatorname{Ir}(\mathrm{ppy})_{2}(\mathrm{~F} 5 \mathrm{Phpz} 3 \mathrm{py})\right]\left[\mathrm{PF}_{6}\right]$ (CSD refcodes BAWSID and BAWOJ) [105].

Scheme 14 includes $\mathrm{N}^{\wedge} \mathrm{N}$ ligands with one or two imidazole units. In solution, $\left[\operatorname{Ir}(\mathrm{ppy})_{2}(\mathrm{EPimid})\right]\left[\mathrm{PF}_{6}\right]$ is a blue emitter $\left(\lambda_{\mathrm{em}}{ }^{\max }=488 \mathrm{~nm}\right.$ with shoulder at $511 \mathrm{~nm}$ ), but there was a red-shift to $525 \mathrm{~nm}$ on going to thin-film. The effect of replacing $[\mathrm{ppy}]^{-}$by $[\mathrm{dfppy}]^{-}$was to push the emissions to higher energy (460, $484 \mathrm{~nm}$ in solution and $505 \mathrm{~nm}$ in thin film). The PL emission maxima observed in thin-film were good models for the EL of LECs in configuration ITO/PEDOT:PSS/Ir-iTMC/Al which emitted green or blue-green light $\left(\mathrm{EL} \lambda_{\mathrm{em}}{ }^{\max }=522\right.$ or $\left.500 \mathrm{~nm}\right)$. However, the presence of the fluoro-groups led to a reduction in light intensity $\left(L_{\max }=1191 \mathrm{~cd} \mathrm{~m}^{-2}\right.$ for $\left[\operatorname{Ir}(\text { ppy })_{2}(\right.$ EPimid) $]\left[\mathrm{PF}_{6}\right]$ and $741 \mathrm{~cd} \mathrm{~m}^{-2}$ for $\left[\operatorname{Ir}(\mathrm{dfppy})_{2}(\right.$ EPimid)][PF 6$\left.]\right)[106] .0 \mathrm{On}$ going from the archetype $\operatorname{Ir}-\mathrm{iTMC}\left[\operatorname{Ir}(\mathrm{ppy})_{2}(\mathrm{bpy})\right]\left[\mathrm{PF}_{6}\right]$ to $\left[\operatorname{Ir}(\mathrm{ppy})_{2}(\mathrm{pyim})\right]\left[\mathrm{PF}_{6}\right]$ to $\left[\operatorname{Ir}(\mathrm{ppy})_{2}(\mathrm{bid})\right]\left[\mathrm{PF}_{6}\right]$, solution $(\mathrm{MeCN})$ values of the PL $\lambda_{\mathrm{em}}{ }^{\max }$ undergo a significant blue-shift from 585 to 554 to $496 \mathrm{~nm}$ corresponding to the sequential replacement of one, then two, pyridine rings in bpy by imidazole. The related complexes $\left[\operatorname{Ir}(\text { ppy })_{2}(\mathrm{Phpybi})\right]\left[\mathrm{PF}_{6}\right]$ and $\left[\operatorname{Ir}(\mathrm{ppy})_{2}(\mathrm{qlbi})\right]\left[\mathrm{PF}_{6}\right]$ in which the benzimidazole units extend the aromatic system of the $\mathrm{N}^{\wedge} \mathrm{N}$ ligand, exhibit $\lambda_{\mathrm{em}}{ }^{\max }$ 
at 588 and $627 \mathrm{~nm}$, respectively, thereby pushing the emission maximum back towards the red. We return to this phenomenon in Section 7. LECs with configuration ITO/PEDOT:PSS/Ir-iTMC:[BMIM][PF 6$](\approx 3: 1) / \mathrm{Al}$ in which Ir-iTMC is $\quad\left[\operatorname{Ir}(\text { ppy })_{2}(\right.$ pyim $\left.)\right]\left[\mathrm{PF}_{6}\right], \quad\left[\operatorname{Ir}(\mathrm{ppy})_{2}(\mathrm{bid})\right]\left[\mathrm{PF}_{6}\right], \quad\left[\operatorname{Ir}(\mathrm{ppy})_{2}(\mathrm{Phpybi})\right]\left[\mathrm{PF}_{6}\right] \quad$ or $\left[\operatorname{Ir}(\mathrm{ppy})_{2}(\mathrm{qlbi})\right]\left[\mathrm{PF}_{6}\right]$, were slow to turn-on, taking between 2.9 and $8.6 \mathrm{~h}$ to reach $L_{\text {max }}$. The EL spectra are similar to the PL spectra, showing only a relatively small $(\sim 10 \mathrm{~nm})$ shift towards the red. Blue-green-light emitting LECs were obtained by replacing [ppy $^{-}$in $\left[\operatorname{Ir}(\mathrm{ppy})_{2}(\mathrm{pyim})\right]\left[\mathrm{PF}_{6}\right]$ and $\left[\operatorname{Ir}(\mathrm{ppy})_{2}(\mathrm{Phpybi})\right]\left[\mathrm{PF}_{6}\right]$ by [dfppy] $^{-}$. The range of LEC colours obtained in this investigation encouraged the fabrication of devices with blended electroluminophores in the active layer. By doping $[10,107]$ the red-emitting $\left[\operatorname{Ir}(\mathrm{ppy})_{2}(\mathrm{qlbi})\right]\left[\mathrm{PF}_{6}\right]$ into a LEC based primarily on $\left[\operatorname{Ir}(\mathrm{dfppy})_{2}(\mathrm{pyim})\right]\left[\mathrm{PF}_{6}\right]$, white-light emission was achieved. Qiu and coworkers [108] reported EL spectra with two maxima at $\sim 497$ and $590 \mathrm{~nm}$, the relative intensities of which depend upon the level of doping. Values of $L_{\max }$ are, however, low (31 to $115 \mathrm{~cd} \mathrm{~m}^{-2}$ ). On going from $\left[\operatorname{Ir}(\mathrm{ppy})_{2}(\mathrm{Mepybi})\right]\left[\mathrm{PF}_{6}\right]$ to $\left[\operatorname{Ir}(\text { ppy })_{2}\left(\right.\right.$ Etpybi)] $\left[\mathrm{PF}_{6}\right]$ to $\left[\operatorname{Ir}(\mathrm{ppy})_{2}(\mathrm{Octpybi})\right]\left[\mathrm{PF}_{6}\right]$ (see Scheme 14), the length of the $\mathrm{N}$-alkyl substituent on the imidazole ring increases. This has little effect on the solution PL $\left(\lambda_{\mathrm{em}}{ }^{\max }=572,579\right.$ and $\left.576 \mathrm{~nm}\right)$ and the complexes are all yellow emitters and exhibit good PLQYs (range 43-54\%). In contrast, the chain length impacted significantly on LEC performance. LECs in configuration ITO/PEDOT:PSS/Ir-iTMC/Al had values of $L_{\max }=2842(N$-methyl), $2933(N-$ ethyl) and $7309 \mathrm{~cd} \mathrm{~m}^{-2}$ (N-octyl), and this trend was explained in terms of reduced intermolecular interactions as the chain length increased leading to less self-quenching [109]. 
The complexes $\left[\operatorname{Ir}(\mathrm{dfppy})_{2}(\text { pytriaz-R) }]^{+}\right.$combine a 1,2,3-triazole-based $\mathrm{N}^{\wedge} \mathrm{N}$ domain (pytriaz-R with $\mathrm{R}=$ phenyl, benzyl, biphenyl or adamantyl, Scheme 14) with a difluoro-substituted cyclometallating ligand. De Cola and coworkers reported $\left[\operatorname{Ir}(\mathrm{dfppy})_{2}(\right.$ pytriaz-R)][PF$]$ and $\left[\operatorname{Ir}(\mathrm{dfppy})_{2}(\right.$ pytriaz-R)][BF 4$]$ in an investigation of the effects of both the R group and counter-ion. Solutions of the compounds exhibited structured emission spectra (see Section 1) with values of $\lambda_{\mathrm{em}}{ }^{\max }(\sim 452$ and $482 \mathrm{~nm})$ being independent of both R and counter-ion. LECs in configuration ITO/PEDOT:PSS/Ir-iTMC:[TBA][OTf] (1:1)/Al were made using six of the $\left[\operatorname{Ir}(\mathrm{dfppy})_{2}(\right.$ pytriaz-R)][X] series and were operated at a constant voltage of $5 \mathrm{~V}$. Values of $t_{\mathrm{on}}$ (time to reach $L_{\max }$ ) ranged from 120 to $860 \mathrm{~s}$, and the LECs emitted blue light (structured EL $\lambda_{\mathrm{em}}{ }^{\max } \sim 460$ and $488 \mathrm{~nm}$ in each LEC). This family of electroluminophores is significant in generating LEC emissions that were described by the authors as the 'bluest with fastest response time ever reported for iridium complexes' [110]. However, the device lifetimes were low with values of $t_{1 / 2}$ in the range 3.4 to $38.0 \mathrm{~min}$. In Section 6.3, we described the electroluminophore $\left[\operatorname{Ir}(\mathrm{Phtl})_{2}(\mathrm{bpy})\right]\left[\mathrm{PF}_{6}\right]$, and the protection that the pendant benzyl moiety in the [Phtl]- ligand imparts upon the iridium centre (see Fig. 10). Extension of this work invoked the use of $\mathrm{H}(\mathrm{fPhtl})$ and $\mathrm{H}(\mathrm{dfPhtl})$ in combination with the nitrogen-rich $\mathrm{N}^{\wedge} \mathrm{N}$ ligands pytriaz- $\mathrm{R}$ with $\mathrm{R}=\mathrm{Ph}$ or benzyl (Scheme 15) [111]. Blue-light-emitting LECs were achieved for each of the Ir-iTMCs shown in Scheme 15. Room temperature solution PL spectra for $\left[\operatorname{Ir}(\mathrm{fPhtl})_{2}(\mathrm{pytriaz-}\right.$ $\mathrm{Ph}]\left[\mathrm{PF}_{6}\right],\left[\operatorname{Ir}(\mathrm{fPhtl})_{2}\left(\right.\right.$ pytriaz-Bn] $\left[\mathrm{PF}_{6}\right],\left[\operatorname{Ir}(\mathrm{dfPhtl})_{2}\left(\right.\right.$ pytriaz-Ph] $\left[\mathrm{PF}_{6}\right]$ and $\left[\operatorname{Ir}(\mathrm{dfPhtl})_{2}\right.$ (pytriaz-Bn][PF$]$ exhibit maxima at 487, 461, 485 and $452 \mathrm{~nm}$, respectively, corresponding to sky-blue or deep-blue emissions. The trend demonstrated the expected blue shift on going from one to two $\mathrm{F}$ atoms per $\mathrm{C}^{\wedge} \mathrm{N}$ 
domain. The change from phenyl to benzyl group in the $\mathrm{N}^{\wedge} \mathrm{N}$ ligand has negligible effect on PL $\lambda_{\mathrm{em}}{ }^{\mathrm{max}}$, consistent with related studies of the effects of $N$ substitution in triazole units $[94,105,110]$. LECs were fabricated in configuration ITO/PEDOT:PSS/iTMC + 0.3\% $\mathrm{LiPF}_{6} / \mathrm{LiF} / \mathrm{Al}$; the incorporation of LiF to enhance ion mobility was discussed in Section 5.1 [60]. Although the EL spectra were redshifted with respect to PL maxima, the LEC with [Ir(fPhtl) $)_{2}$ (pytriaz-Bn] $\left[\mathrm{PF}_{6}\right]$ in the active layer retains a deep-blue emission (EL $\left.\lambda_{\mathrm{em}}{ }^{\max }=487 \mathrm{~nm}\right)$. Under a constant $9 \mathrm{~V}$ bias, turn-on of the LECs was between $6 \mathrm{~min}$ and $2 \mathrm{~h}$, and values of $t_{1 / 2}$ ranged from 0.8 to $6 \mathrm{~h}[111]$.

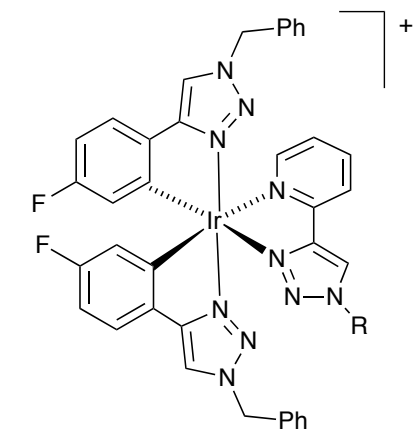

$\left[\operatorname{lr}(\mathrm{fPhtl})_{2}(\text { pytriaz-Ph) }]^{+} \mathrm{R}=\mathrm{Ph}\right.$ $\left[\operatorname{lr}(\mathrm{fPhtl})_{2}(\text { pytriaz-Bn) }]^{+} \mathrm{R}=\right.$ benzyl

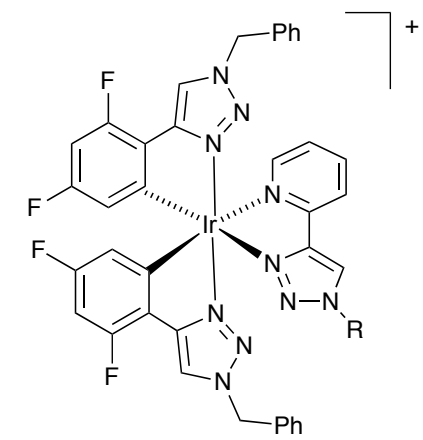

$\left[\operatorname{lr}(\mathrm{dfPhtl})_{2}(\text { pytriaz-Ph) }]^{+} \mathrm{R}=\mathrm{Ph}\right.$ $\left[\operatorname{Ir}(\mathrm{dfPhtl})_{2}(\text { pytriaz-Bn) }]^{+} \mathrm{R}=\right.$ benzyl

Scheme 15. Ir-iTMCs combining nitrogen-rich $\mathrm{N}^{\wedge} \mathrm{N}$ and $\mathrm{C}^{\wedge} \mathrm{N}$ ligands with introduction of electron-withdrawing fluoro-groups in the $\mathrm{C}^{\wedge} \mathrm{N}$ domains.

Following the theme of the strong electron-donating ability of triazolebased ligands, $\mathrm{Wu}$ and coworkers chose to investigate a series of $\left[\operatorname{Ir}\left(\mathrm{C}^{\wedge} \mathrm{N}\right)_{2}\left(\mathrm{~N}^{\wedge} \mathrm{N}\right)\right]\left[\mathrm{PF}_{6}\right]$ compounds in which $\mathrm{N}^{\wedge} \mathrm{N}$ was a 1,2,4-triazole-based ligand (pytriaz-oct or pytriaz-octCN, Scheme 14). The cyclometallating ligands were H(dfppy) or 2-(4-tolyl)pyridine H(tolpy). Structured emissions were 
observed for solutions of $\left[\operatorname{Ir}(\mathrm{dfppy})_{2}(\right.$ pytriaz-octCN)][PF 6$],\left[\operatorname{Ir}(\text { tolppy })_{2}\right.$ (pytriazoctCN)][PF 6$],\left[\operatorname{Ir}(\mathrm{dfppy})_{2}\right.$ (pytriaz-oct)][PF 6$]$ or [Ir(tolppy) ${ }_{2}$ (pytriaz-oct)][PF 6$]$. The [dfppy]--containing compounds were sky-blue emitters $\left(\lambda_{\mathrm{em}}{ }^{\max }=454,485\right.$ $\mathrm{nm})$, while the use of [tolppy] $]^{-}$in place of [dfppy $]^{-}$resulted in a blue-green emission $\left(\lambda_{\mathrm{em}}{ }^{\max }=480,512 \mathrm{~nm}\right)$. The EL of LECs of configuration ITO/PEDOT:PSS/Ir-iTMC:[BMIM][PF6] (14\%wt IL)/Al was slightly red-shifted with respect to the PL, but still retained sky-blue or blue-green emissions. When driven under a constant $5 \mathrm{~V}$ voltage, the LECs containing [Ir(tolppy) 2 (pytriazoctCN)][PF 6 or [Ir(tolppy) 2 (pytriaz-oct)][PF 6 achieved $L_{\max }$ values of 430 or 228 $\mathrm{cd} \mathrm{m}^{-2}$, respectively. Luminance levels dropped when fluoro-substituents were present in the electroluminophore. LEC efficiencies were enhanced by introducing the cyano functionality. Thus, of this series, the best-performing LEC with the fastest turn-on time contained $\left[\operatorname{Ir}\left(\right.\right.$ tolppy) ${ }_{2}($ pytriaz-octCN)][PF 6$]$ in the active layer [112].

\section{5 $N$-heterocyclic carbenes: $\left[\operatorname{Ir}\left(\mathrm{C}^{\wedge} \mathrm{N}\right)_{2}(\mathrm{NHC})\right]^{+}$complexes}

Replacing the $\mathrm{N}^{\wedge} \mathrm{N}$ ligand in $\left[\operatorname{Ir}\left(\mathrm{C}^{\wedge} \mathrm{N}\right)_{2}\left(\mathrm{~N}^{\wedge} \mathrm{N}\right)\right]^{+}$by a strong-field, chelating $N^{-}$ heterocyclic carbene was first reported in 2010 by De Cola and coworkers as a means of achieving blue-light-emitting LECs [39]. Scheme 16 shows some of the NHCs that have been investigated during the last few years. Both Me-mdiim and Bu-mdiim are chelating NHCs, illustrated in the structure of the $\left[\operatorname{Ir}(\mathrm{dfppy})_{2}(\mathrm{Bu}-\right.$ mdiim) $]^{+}$cation shown in Fig. 13. In solution, [Ir(dfppy) $\left.{ }_{2}(\mathrm{Me}-\mathrm{Idiim})\right]\left[\mathrm{PF}_{6}\right]$, $\left[\operatorname{Ir}(\mathrm{dfppy})_{2}(\mathrm{Me}-\mathrm{mdiim})\right][\mathrm{BF} 4],\left[\operatorname{Ir}(\mathrm{dfppy})_{2}(\mathrm{Bu}-\mathrm{mdiim})\right]\left[\mathrm{PF}_{6}\right]$ and $\left[\operatorname{Ir}(\mathrm{dfppy})_{2}(\mathrm{Bu}-\right.$ mdiim) $]\left[\mathrm{BF}_{4}\right]$ are blue-emitters with structured emission (PL $\lambda_{\mathrm{em}}{ }^{\max }=452$ and $482 \mathrm{~nm}$ for $\left[\mathrm{PF}_{6}\right]^{-}$salts and 452 and $480 \mathrm{~nm}$ for $\left[\mathrm{BF}_{4}\right]^{-}$salts). The result 
confirmed the combined effects of fluorinated $\mathrm{C}^{\wedge} \mathrm{N}$ ligand with strong field $\mathrm{NHC}$ in terms of widening the HOMO-LUMO gap and attaining a blue emission. Compare, for example, with $\left[\operatorname{Ir}(\mathrm{Me}-\mathrm{dfppy})_{2}\left(4,4^{\prime}-\mathrm{BBu}_{2} \mathrm{bpy}\right)\right]\left[\mathrm{PF}_{6}\right]$ which is a green emitter in solution (see Section 6.1). LECs in configuration ITO/PEDOT:PSS/IriTMC:[TBA][OTf] (1:1)/Al emitted blue light (EL $\lambda_{\mathrm{em}}{ }^{\max }=488 \mathrm{~nm}$ for $\left[\operatorname{Ir}(\mathrm{dfppy})_{2}(\mathrm{Me}-\mathrm{mdiim})\right][\mathrm{X}]$ and 456 or $488 \mathrm{~nm}$ for [Ir(dfppy) $\left.)_{2}(\mathrm{Bu}-\mathrm{mdiim})\right][\mathrm{X}]$, $[\mathrm{X}]^{-}=\left[\mathrm{PF}_{6}\right]^{-}$or $\left.\left[\mathrm{BF}_{4}\right]^{-}\right)$. The LECs were operated using a voltage sweep mode (VSM) or a constant voltage mode (CVM). The brightest LEC achieved $L_{\max }=$ $159.8 \mathrm{~cd} \mathrm{~m}^{-2}$ (VSM). The stability of the LECs was relatively low with the longestlived LEC $\left(t_{1 / 2}=53.8 \mathrm{~min}\right)$ also being the brightest [39]. The NHC Me-mdiim has also been combined with the cyclometallating ligand $\mathrm{H}\left(\mathrm{dfpypy}^{\mathrm{t}} \mathrm{Bu}\right.$ ) (Scheme 17) in the Ir-iTMC $\left[\operatorname{Ir}\left(\mathrm{dfpypy}^{t} \mathrm{Bu}\right)_{2}(\mathrm{Me}-\mathrm{mdiim})\right]\left[\mathrm{PF}_{6}\right]$. The bulky ${ }^{t} \mathrm{Bu}$ substituents were designed to limit intermolecular interactions (see Section 5). Excitation in solution results in a deep-blue emission (PL $\left.\lambda_{\mathrm{em}}{ }^{\max }=440 \mathrm{~nm}\right)$. Results of DFT/TD-DFT calculations indicated that the PL originates from the cyclometallating rather than NHC ligand which is in contrast to typical $\left[\operatorname{Ir}\left(\mathrm{C}^{\wedge} \mathrm{N}\right)_{2}\left(\mathrm{~N}^{\wedge} \mathrm{N}\right)\right]^{+} \operatorname{Ir}-\mathrm{iTMC}$ in which emission originates from the $\mathrm{N}^{\wedge} \mathrm{N}$ ligand. A LEC in configuration ITO/PEDOT:PSS/Ir-iTMC:[BMIM][PF $]$ (3:1)/Al with $\left[\operatorname{Ir}\left(\mathrm{dfpypy}^{t} \mathrm{Bu}\right)_{2}(\mathrm{Me}-\mathrm{mdiim})\right]\left[\mathrm{PF}_{6}\right]$ in the active layer and operated under a constant $6 \mathrm{~V}$ voltage, exhibited a time-dependent EL spectrum with the maximum shifting from $\sim 500 \mathrm{~nm}$ to $532 \mathrm{~nm}$ and the profile of the spectrum changing substantially over time. Operating the LEC under $2.5 \mathrm{~mA} \mathrm{~cm}^{-2}$ constant current rather than $6 \mathrm{~V}$ constant voltage led to a faster turn-on (17 s vs $215 \mathrm{~s}$ ) and higher $L_{\max }\left(113 v s 15 \mathrm{~cd} \mathrm{~m}^{-2}\right)$. The LEC had poor long-term stability $\left(t_{1 / 2}=\right.$ $179 \mathrm{~s}$ under constant bias and only $60 \mathrm{~s}$ under constant current mode) [113]. 
The use of different LEC driving conditions in these last two investigations underlines the difficulties of assessing device performance for a given electroluminophore based on a single set of operating parameters.

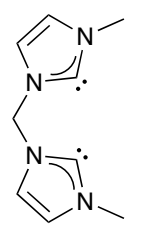

Me-mdiim

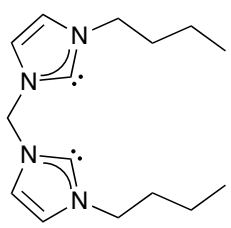

Bu-mdiim<smiles></smiles>

pymeim<smiles>Cc1ccnc(N2Nc3ccccc3N2C)c1</smiles>

pybzim

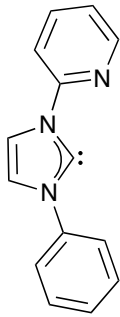

pyphmi

Scheme 16. Structures of selected $N$-heterocyclic carbenes.

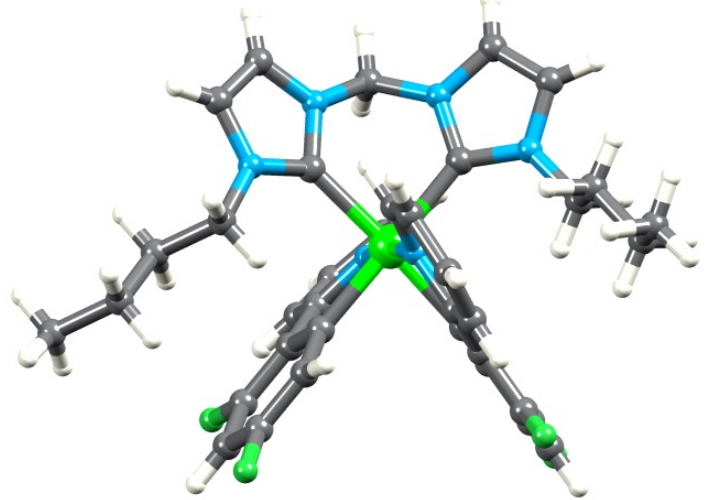

Fig. 13. The crystallographically determined structure of $\left[\operatorname{Ir}(\mathrm{dfppy})_{2}(\mathrm{Bu}-\right.$ mdiim) $]^{+}$from the $\left[\mathrm{PF}_{6}\right]^{-}$salt (CSD refcode IMOWAJ) [39].

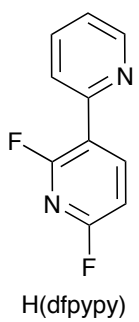<smiles>Fc1ccc(-c2cc(Br)ccn2)c(F)n1</smiles><smiles>CC(=O)OC(C)=O</smiles><smiles>CC(=O)c1ccnc(-c2ccccc2)c1</smiles>

Scheme 17. Some cyclometallating ligands used in combination with NHCs in $\left[\operatorname{Ir}\left(\mathrm{C}^{\wedge} \mathrm{N}\right)_{2}(\mathrm{NHC})\right]^{+}$complexes. See also H(dfppy) in Scheme 9 and H(dfppz) in Fig. 9. 
The ligands pymeim, pyphmi and pybzim present an $\mathrm{N}^{\wedge} \mathrm{C}$ donor set, the $\mathrm{C}$ donor being an NHC (Scheme 16). These have been used in conjunction with the cyclometallating ligands H(ppy), H(dfppy), H(dfppz), H(dfpypy), H(dfpypytBu), $\mathrm{H}\left(\mathrm{dfpypyCO}{ }_{2} \mathrm{Me}\right.$ ) and $\mathrm{H}\left(4-\mathrm{MeCO}_{2} \mathrm{C}-2\right.$-Phpy) (Scheme 17) in Ir-iTMCs. A series of $\left[\operatorname{Ir}\left(\mathrm{C}^{\wedge} \mathrm{N}\right)_{2}(\right.$ pybzim $\left.)\right]\left[\mathrm{PF}_{6}\right]$ complexes exhibited poor PL characteristics and (as above for $\left.\left[\operatorname{Ir}\left(\mathrm{dfpypy}^{t} \mathrm{Bu}\right)_{2}(\mathrm{Me}-\mathrm{mdiim})\right]\left[\mathrm{PF}_{6}\right]\right)$, the results of DFT/TD-DFT calculations are consistent with PL originating from the cyclometallating ligand. Solution PL maxima of $435 \mathrm{~nm}$ for [Ir(dfpypy) 2 (pybzim)][PF 6 , $447 \mathrm{~nm}$ for $\left[\operatorname{Ir}\left(\mathrm{dfpypyCO}{ }_{2} \mathrm{Me}\right)_{2}(\right.$ pybzim $\left.)\right]\left[\mathrm{PF}_{6}\right]$ and $450 \mathrm{~nm}$ for $\left[\operatorname{Ir}(\mathrm{dfppy})_{2}(\right.$ pybzim $\left.)\right]\left[\mathrm{PF}_{6}\right]$ give the desired blue emissions; this PL $\lambda_{\mathrm{em}}{ }^{\text {max }}$ range of $435-450 \mathrm{~nm}$ compares with $\lambda_{\mathrm{em}}{ }^{\max }=471 \mathrm{~nm}$ for $\left[\operatorname{Ir}(\mathrm{ppy})_{2}(\right.$ pybzim $\left.)\right]\left[\mathrm{PF}_{6}\right]$ which bears no fluorosubstituents. The deep-blue emission from $\left[\operatorname{Ir}(\mathrm{dfpypy})_{2}(\right.$ pybzim) $]\left[\mathrm{PF}_{6}\right]$ is especially noteworthy, being at significantly higher energy than blue emitting IriTMCs employing diimine ancillary ligands. Members of this series of compounds show rather low PLQYs and this was ascribed to non-radiative deactivation of the excited states by thermally accessible iridium-centred states [114]. LECs in configuration ITO/PEDOT:PSS/Ir-iTMC:[BMIM][PF 6$]$ (3:1)/Al with $\left[\operatorname{Ir}\left(\mathrm{C}^{\wedge} \mathrm{N}\right)_{2}(\right.$ pybzim $\left.)\right]\left[\mathrm{PF}_{6}\right]$ in the emissive layer were operated under a constant 6 V voltage. $\left[\operatorname{Ir}(\mathrm{ppy})_{2}(\right.$ pybzim) $]\left[\mathrm{PF}_{6}\right]$ and $\left[\operatorname{Ir}(\mathrm{dfppy})_{2}(\mathrm{pybzim})\right]\left[\mathrm{PF}_{6}\right]$ gave only low luminances $\left(L_{\max } \sim 20 \mathrm{~cd} \mathrm{~m}^{-2}\right)$ and, disappointingly, a large red-shift was observed from solution PL to device EL $\left(E L \lambda_{\mathrm{em}}{ }^{\max }=544\right.$ and $512 \mathrm{~nm}$ compared to PL $\lambda_{\mathrm{em}}{ }^{\max }=471$ and $450 \mathrm{~nm}$, respectively) [114]. With the knowledge that intra-cation $\pi$-stacking interactions can improve LEC stability, Duan and Qiu [115] introduced an $N$-phenyl substituent into the NHC ligand pyphmi (Scheme 16). The crystallographically determined structure of the cation in 
$\left[\operatorname{Ir}(\text { ppy })_{2}(\right.$ pyphmi) $]\left[\mathrm{PF}_{6}\right]$ is shown in Fig. 14. Photoexcitation of the compound in solution leads to a blue-green emission; the structured emission had maxima at 500 and $477 \mathrm{~nm}$, and there was only a small red-shift on going to thin-film (PL $\lambda_{\mathrm{em}}{ }^{\max }=506$ and $480 \mathrm{~nm}$ ). Although this looked promising, LECs in configuration IT/PEDOT:PSS/IriTMC:[BMIM][PF $]$ (4:1)/Al and operated under a constant $4 \mathrm{~V}$ bias emitted yellow light $\left(E L \lambda_{\mathrm{em}}{ }^{\max }=556 \mathrm{~nm}\right)$. Perhaps surprisingly, LECs with $\left[\operatorname{Ir}(\mathrm{ppy})_{2}(\mathrm{pyphmi})\right]\left[\mathrm{PF}_{6}\right]$ in the active layer did not show enhanced stability over those with $\left[\operatorname{Ir}(\mathrm{ppy})_{2}(\mathrm{pymemi})\right]\left[\mathrm{PF}_{6}\right]$ (Scheme 16) suggesting that the $\pi$-stacking interaction is not effective in this case [115]. Independent DFT/TD-DFT calculations by Costa et al. revealed that population of the metal-centred ${ }^{3} \mathrm{MC}$ excited states leads to cleavage of the Ir-N bond to the pyridine ring of the HNC ligand [116]. Thus, the combined experimental and theoretical results lead to the conclusion that the intra-cation $\pi$-stacking which is effective in $\left[\operatorname{Ir}\left(\mathrm{C}^{\wedge} \mathrm{N}\right)_{2}\left(\mathrm{~N}^{\wedge} \mathrm{N}\right)\right]^{+}$ electroluminophores may not enhance the LEC stability in $\left[\operatorname{Ir}\left(\mathrm{C}^{\wedge} \mathrm{N}\right)_{2}(\mathrm{NHC})\right]^{+-}$-type materials.

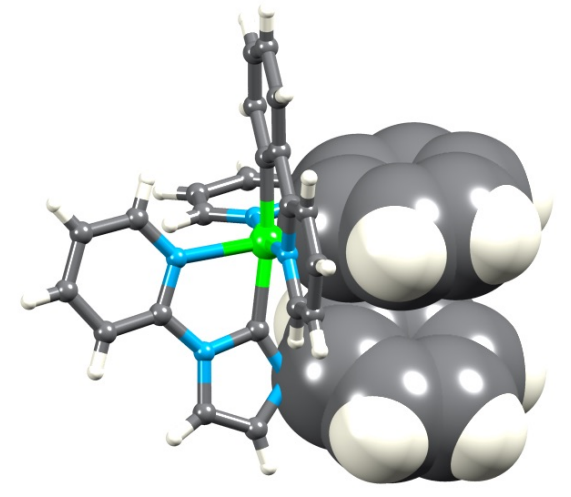

Fig. 14. Intra-cation $\pi$-stacking in the cation in $\left[\operatorname{Ir}(\mathrm{ppy})_{2}\right.$ (pyphmi)][PF 6$]$ (CSD refcode MEGLUH) [115].

\section{$7 \quad$ Red-shifting the emission}


In Section 6, we described the significant efforts that have been made to target deep-blue emitters required to complement the many orange emitting Ir-iTMCs in order to achieve white-light LECs by colour-blending. We illustrated one example from Qiu and coworkers in which a LEC based on the blue-greenemitting $\left[\operatorname{Ir}(\mathrm{dfppy})_{2}(\mathrm{pyim})\right]\left[\mathrm{PF}_{6}\right]$ was doped with the red-emitting $\left[\operatorname{Ir}(\mathrm{ppy})_{2}(\mathrm{qlbi})\right]\left[\mathrm{PF}_{6}\right]$ to gain overall white-light emission [108]. Other examples are included below. LECs exhibiting deep-red emission are few in number and red-emitting LECs with long-term stability are even fewer.<smiles>c1ccc2nc(-c3ccc4ccccc4n3)ccc2c1</smiles>

biq<smiles>CCOC(=O)c1ccnc(-c2cc(C(=O)OCC)ccn2)c1</smiles>

$4,4^{\prime}-\left(\mathrm{EtO}_{2} \mathrm{C}\right)_{2} \mathrm{bpy}$

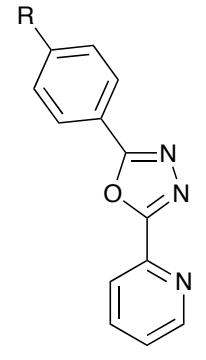

oxd $\mathrm{R}=\mathrm{H}$ or $\mathrm{Me}$

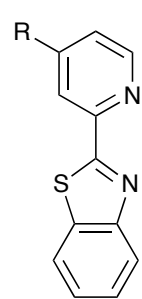
$\begin{array}{llll}\text { pybzt } & \mathrm{R}=\mathrm{H} & \text { Phpybzt } & \mathrm{R}=\mathrm{H} \\ \text { tBupybzt } & \mathrm{R}=\mathrm{H} \text { Bu } & \text { PhtBupybzt } \mathrm{R}=\mathrm{B} u\end{array}$

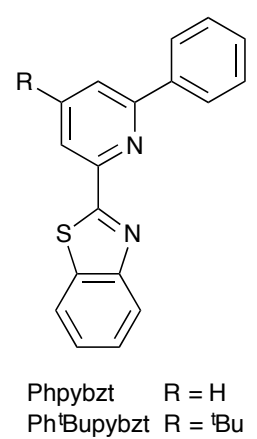

pybibzt

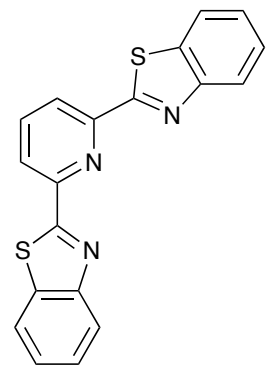

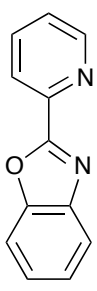

pybzo

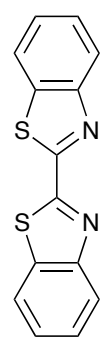

dbzt

Scheme 18. Structures of some $\mathrm{N}^{\wedge} \mathrm{N}$ ligands designed for use in red-emitting IriTMCs. 


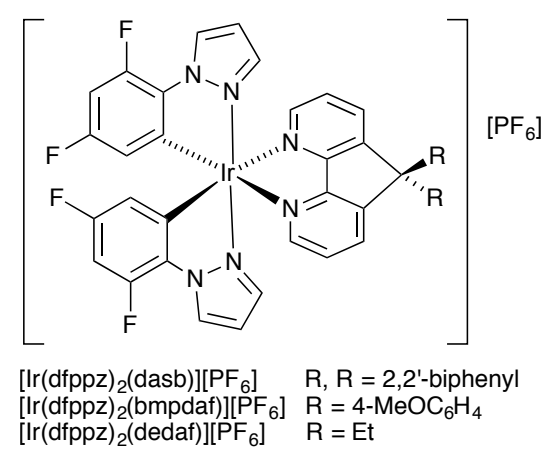

Scheme 19. Blue-green emitters used in host-guest Ir-iTMCs with $\left[\operatorname{Ir}(\mathrm{ppy})_{2}(\mathrm{biq})\right]\left[\mathrm{PF}_{6}\right]$.

An important strategy for obtaining a red-shifted emission is to extend the aromatic system of the $\mathrm{N}^{\wedge} \mathrm{N}$ ligand, for example replacing bpy by 2,2 'biquinoline (biq, Scheme 18). Its use for red-emitting LECs was first reported by Thompson [83] who demonstrated that $\left[\operatorname{Ir}(\mathrm{ppz})_{2}(\mathrm{biq})\right]\left[\mathrm{PF}_{6}\right]$ in MeCN exhibited $\mathrm{PL} \lambda_{\mathrm{em}}{ }^{\max }=616 \mathrm{~nm}$ compared with $\lambda_{\mathrm{em}}{ }^{\mathrm{max}}=563 \mathrm{~nm}$ for $\left[\operatorname{Ir}(\mathrm{ppz})_{2}(\mathrm{bpy})\right]\left[\mathrm{PF}_{6}\right]$ (also in MeCN solution). The emission can be shifted to $627 \mathrm{~nm}$ by using 1-(3(tert-butyl)phenyl)-1H-pyrazole, H(tBuppz), in place of 1-phenyl-1H-pyrazole, $\mathrm{H}(\mathrm{ppz})$, as the cyclometallating ligand. A LEC of configuration ITO/PEDOT:PSS/Ir-iTMC/Al containing [Ir( $\left.\left.{ }^{\mathrm{t} B u p p z}\right)_{2}(\mathrm{biq})\right]\left[\mathrm{PF}_{6}\right]$ emitted red-light $\left(\mathrm{EL} \lambda_{\mathrm{em}}{ }^{\max }=635 \mathrm{~nm}\right)$. Although the LEC was slow to turn on and reached a maximum efficiency (EQE) of 7.4\% after $\sim 70 \mathrm{~min}\left(L_{\max }=7500 \mathrm{~cd} \mathrm{~m}^{-2}\right)$, this seminal work demonstrated that red-light emitting LECs could be accomplished by employing $\mathrm{N}^{\wedge} \mathrm{N}$ ligands with extended $\pi$-conjugation. Since $H(\mathrm{ppz})$ is used in place of H(ppy) to blue-shift emissions (see Section 6.3), it is to be expected that going from $\left[\operatorname{Ir}(\mathrm{ppz})_{2}(\mathrm{biq})\right]\left[\mathrm{PF}_{6}\right][83]$ to $\left[\operatorname{Ir}(\mathrm{ppy})_{2}(\mathrm{biq})\right]\left[\mathrm{PF}_{6}\right][117]$ leads to a shift in the PL to lower energy (616 to $656 \mathrm{~nm}$ ). The red-emitting [ $\left.\operatorname{Ir}(\mathrm{ppy})_{2}(\mathrm{biq})\right]\left[\mathrm{PF}_{6}\right]$ (Fig. 15) has been combined with blue-green emitters shown in host-guest Ir- 
iTMCs configuration to produce solid-state white light-emitting LECs. The bluegreen emitters shown in Scheme 19 showed solution PL maxima of 499, 497 and $491 \mathrm{~nm}$, respectively, with PLQY values of 46, 66 and 54\%. On going to a neat film, the emission shifted to 513 and $507 \mathrm{~nm}$ for $\left[\operatorname{Ir}(\mathrm{dfppz})_{2}(\mathrm{dasb})\right]\left[\mathrm{PF}_{6}\right]$ and [Ir(dfppz $\left.)_{2}(\mathrm{bmpdaf})\right]\left[\mathrm{PF}_{6}\right]$, respectively, but remained at $491 \mathrm{~nm}$ for $\left[\operatorname{Ir}(\mathrm{dfppz})_{2}(\mathrm{dedaf})\right]\left[\mathrm{PF}_{6}\right]$ (see Scheme 19). $\left[\operatorname{Ir}(\mathrm{dfppz})_{2}(\mathrm{dedaf})\right]\left[\mathrm{PF}_{6}\right]$ was therefore selected for combination with $\left[\operatorname{Ir}(\mathrm{ppy})_{2}(\mathrm{biq})\right]\left[\mathrm{PF}_{6}\right]$ in a LEC of configuration ITO/Ir-iTMC:[BMIM] $\left[\mathrm{PF}_{6}\right] / \mathrm{Ag}$ where the active layer comprised host $\left[\operatorname{Ir}(\mathrm{dfppz})_{2}(\mathrm{dedaf})\right]\left[\mathrm{PF}_{6}\right]\left(80.5\right.$ wt. \%), guest $\left[\operatorname{Ir}(\mathrm{ppy})_{2}(\mathrm{biq})\right]\left[\mathrm{PF}_{6}\right](0.4$ wt. \%) and [BMIM][PF 6$]$ (19.1 wt. \%). Operated under constant bias of 2.9, 3.1 or $3.3 \mathrm{~V}$, white-light emitting LECs reached maximum luminance in 240, 60 or $30 \mathrm{~min}$ with the corresponding values of $L_{\max }=2.5,18$ or $43 \mathrm{~cd} \mathrm{~m}^{-2}$. Pleasingly, the blue component in the EL spectrum exhibited a $\lambda_{\mathrm{em}}{ }^{\max }$ of $488 \mathrm{~nm}$, one of the highestenergy blue EL emissions reported at the time (2008) in LECs [117]. Mudring and coworkers [118] have obtained a deep-red-emitting LEC by using $\left[\operatorname{Ir}(\mathrm{bzq})_{2}(\mathrm{biq})\right]\left[\mathrm{PF}_{6}\right]$ in the active layer $(\mathrm{Hbzq}=$ benzo[h]quinoline $)$. The rigid $\mathrm{C}^{\wedge} \mathrm{N}$ ligands were chosen so as to restrict radiationless exciton decay; one of the factors that contributes to the poor stability of many red-emitting Ir-iTMCs is reabsorption of the low energy of the emission leading to vibronic excitation. The solution and powder PL spectra of $\left[\operatorname{Ir}(\mathrm{bzq})_{2}(\mathrm{biq})\right]\left[\mathrm{PF}_{6}\right]$ both exhibit maxima at $644 \mathrm{~nm}$ with a shoulder at $712 \mathrm{~nm}$. A LEC in configuration ITO/PEDOT:PSS/IriTMC:[BMIM][PF6] $(3: 1) / \mathrm{Al}$ showed EL $\lambda_{\mathrm{em}}{ }^{\max }=662 \mathrm{~nm}$. Operated in pulsed current mode, the device achieved $L_{\max }=33.65 \mathrm{~cd} \mathrm{~m}^{-2}$ and had an impressive lifetime of $280 \mathrm{~h}$. 


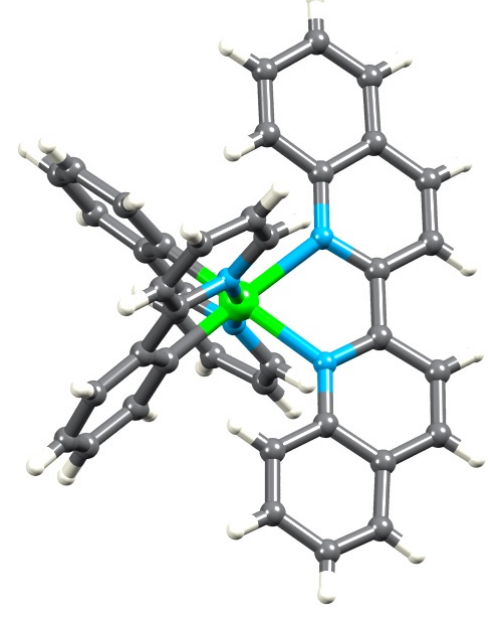

Fig. 15. The crystallographically determined structure of the $\left[\operatorname{Ir}(p p y)_{2}(\mathrm{biq})\right]^{+}$ cation in [Ir(ppy) $\left.)_{2}(\mathrm{biq})\right]\left[\mathrm{PF}_{6}\right]$ (CSD refcode MOBBIP) [117].

The ligand qlbi (Scheme 14) also possesses an extended aromatic system. Like [Ir(ppy) $\left.)_{2}(\mathrm{biq})\right]\left[\mathrm{PF}_{6}\right]\left(\mathrm{PL} \lambda_{\mathrm{em}}{ }^{\max }=656 \mathrm{~nm}\right)[117],\left[\operatorname{Ir}(\mathrm{ppy})_{2}(\mathrm{qlbi})\right]\left[\mathrm{PF}_{6}\right]$ exhibits a red emission in solution (PL $\lambda_{\mathrm{em}}{ }^{\max }=627 \mathrm{~nm}$ with shoulder at 646 nm). A LEC in configuration ITO/PEDOT:PSS/Ir-iTMC:[BMIM][PF6] (3:1)/Al with $\left[\operatorname{Ir}(\mathrm{ppy})_{2}(\mathrm{qlbi})\right]\left[\mathrm{PF}_{6}\right]$ in the emissive layer and driven under a constant $3.0 \mathrm{~V}$ bias retains a satisfyingly red-shifted $\mathrm{EL} \lambda_{\mathrm{em}}{ }^{\max }$ of $650 \mathrm{~nm}$. However, the LEC was slow to turn on, taking $12.4 \mathrm{~min}$ to reach a luminance of $1 \mathrm{~cd} \mathrm{~m}^{-2}$ and $7.2 \mathrm{~h}$ to reach a value of $L_{\max }$ of $70 \mathrm{~cd} \mathrm{~m}^{-2}$ [108]. The application of this red-emitter as a dopant in a white-light emitting LEC was described in Section 6.4. [Ir(ppy $\left.)_{2}(\mathrm{qlbi})\right]\left[\mathrm{PF}_{6}\right]$ has also been combined with [Ir(ppz) $2(\mathrm{pzpy}]\left[\mathrm{PF}_{6}\right]$ in a LEC (ITO/PEDOT:PSS/IriTMC:[BMIM] $\left[\mathrm{PF}_{6}\right] / \mathrm{Al}$ ) in which the active layer comprised host $\left[\operatorname{Ir}(\mathrm{ppz})_{2}(\mathrm{pzpy}]\left[\mathrm{PF}_{6}\right]\right.$, guest $\left[\operatorname{Ir}(\mathrm{ppy})_{2}(\mathrm{biq})\right]\left[\mathrm{PF}_{6}\right]$ and ionic liquid; the red-emitting guest was present in $30 \mathrm{wt} \%$. EL spectra of LECs containing the host alone, guest alone or host-guest combination exhibited $\lambda_{\mathrm{em}}{ }^{\max }=493,650$ or $627 \mathrm{~nm}$, respectively. The dispersion of the guest ions within the host inhibits self- 
quenching [10] and although the EQE of the host-guest LEC is greater (3.5\%) than that of the red-emitting guest-alone LEC (2.6\%), the value of $L_{\max }$ is significantly lower (8.4 versus $70.3 \mathrm{~cd} \mathrm{~m}^{-2}$ ) [119].

$\mathrm{Zhu}, \mathrm{Su}$, Bryce and coworkers [120] have reported a series of complexes involving the heterocyclic oxd derivatives as $\mathrm{N}^{\wedge} \mathrm{N}$ ligands. Two of these ligands are shown in Scheme 18 and $\left[\operatorname{Ir}(\mathrm{ppy})_{2}(\mathrm{oxd})\right]\left[\mathrm{PF}_{6}\right]$ complexes exhibit solution PL maxima of 573 and $556 \mathrm{~nm}$ for oxd with $\mathrm{R}=\mathrm{H}$ or Me (Scheme 18). On going to thin films, a red-shift to 625 and $627 \mathrm{~nm}$, respectively, occurs leading to red emission. LECs in configuration ITO/PEDOT:PSS/Ir-iTMC:[BMIM][PF 6 (4:1)/Al (driven under a constant $5 \mathrm{~V}$ bias) emitted red light (EL $\lambda_{\mathrm{em}}{ }^{\max }=616$ and 624 $\mathrm{nm}$ ) and achieved values of $L_{\max }=217$ and $154 \mathrm{~cd} \mathrm{~m}^{-2}$. The LEC with $\left[\operatorname{Ir}(\mathrm{ppy})_{2}(\mathrm{oxd}, \mathrm{R}=\mathrm{Me})\right]\left[\mathrm{PF}_{6}\right]$ exhibits an $\mathrm{EQE}$ of $9.51 \%$ which is particularly high for a red-emitting LEC. Turn-on times were moderate (72 and $35 \mathrm{~min}$ to reach $L_{\max }$ ) and LEC lifetimes were of the order of hours (reported as 590 and $490 \mathrm{~min}$ ) [120]. Scheme 18 shows a series of $\mathrm{N}^{\wedge} \mathrm{N}$ ligands incorporating benzo[d] thiazole or benzo[d]oxazole units which have been employed by our group [121] to produce red-emitting $\left[\operatorname{Ir}(\mathrm{ppy})_{2}\left(\mathrm{~N}^{\wedge} \mathrm{N}\right)\right]\left[\mathrm{PF}_{6}\right]$ complexes. In solution, $\mathrm{PL} \lambda_{\mathrm{em}}{ }^{\max }$ values lie in the range 636 to $686 \mathrm{~nm}$ and show only slight perturbation upon going to thin films (PL $\lambda_{\mathrm{em}}{ }^{\max }=625-693 \mathrm{~nm}$ ); in the solid state, emissions are blue-shifted up to $32 \mathrm{~nm}$ with respect to solution. The introduction of the second benzothiazole unit in pybibzt and dbzt (Scheme 18) leads to a marked stabilization of the LUMO and $\left[\operatorname{Ir}(\mathrm{ppy})_{2}(\mathrm{pybibzt})\right]\left[\mathrm{PF}_{6}\right]$ and $\left[\operatorname{Ir}(\mathrm{ppy})_{2}(\mathrm{dbzt})\right]\left[\mathrm{PF}_{6}\right]$ exhibit the most red-shifted emissions of the series. LECs were made in configuration ITO/PEDOT:PSS/Ir-iTMC:[BMIM][PF 6$]$ (4:1)/Al and were operated using a pulsed current mode. The device containing $\left[\operatorname{Ir}(\mathrm{ppy})_{2}(\mathrm{dbzt})\right]\left[\mathrm{PF}_{6}\right]$ 
emitted in the near-infrared and failed to operate under a pulsed current mode, although did respond under constant-voltage operation. For the remaining LECs, EL $\lambda_{\text {em }}{ }^{\text {max }}$ were in the range 598 to $655 \mathrm{~nm}$. The best-performing LECs contained $\left[\operatorname{Ir}(\text { ppy })_{2}(\right.$ pybzt $\left.)\right]\left[\mathrm{PF}_{6}\right],\left[\operatorname{Ir}(\text { ppy })_{2}\left({ }^{\mathrm{t} B u p y b z t}\right)\right]\left[\mathrm{PF}_{6}\right]$ or $\left[\operatorname{Ir}(\text { ppy })_{2}(\mathrm{Phpybzt})\right]\left[\mathrm{PF}_{6}\right]$ (see Scheme 18), and reached $L_{\max }=77,200$ and $119 \mathrm{~cd} \mathrm{~m}^{-2}$, respectively, in 4.6, 4.3 and $0.2 \mathrm{~h}$. The most remarkable feature of these LECs is their stability with extrapolated $t_{1 / 2}$ values of $>1000,>6000$ and $>4500 \mathrm{~h}$ for $\left[\operatorname{Ir}(\mathrm{ppy})_{2}(\mathrm{pybzt})\right]\left[\mathrm{PF}_{6}\right]$, $\left[\operatorname{Ir}(\text { ppy })_{2}\left({ }^{\mathrm{t} B u p y b z t}\right)\right]\left[\mathrm{PF}_{6}\right]$ and $\left[\operatorname{Ir}(\mathrm{ppy})_{2}(\mathrm{Phpybzt})\right]\left[\mathrm{PF}_{6}\right]$, respectively. This class of $\mathrm{N}^{\wedge} \mathrm{N}$ ligands is therefore worthy of further investigation in Ir-iTMCs. Significantly, the long lifetimes are achieved without the use of the intra-cation $\pi$-stacking interactions discussed in Section 4. We noted in Section 4 that redemitting LECs using Ir-iTMCs in which the $\mathrm{N}^{\wedge} \mathrm{N}$ ligand is a bidentate tpy showed low efficiencies [55]. This $\mathrm{N}^{\wedge} \mathrm{N}$ domain was chosen because it could provide a pendant non-coordinated pyridyl ring to $\pi$-stack over one cyclometallated ring in $\left[\operatorname{Ir}(\mathrm{ppy})_{2}(\mathrm{tpy})\right]^{+}$-type complexes, and could also be variously functionalized in the 4 '-position of the tpy ligand to tune to emission properties $[55,122]$. However, tpy (specifically, the 2,2':6',2"'-isomer) appears not to be a favourable $\mathrm{N}^{\wedge} \mathrm{N}$ component in Ir-iTMCs. On the other hand, the isomeric 2,2':5',2"terpyridine (2,5-tpy) was used by Slinker and Zysman-Colman in $\left[\operatorname{Ir}(p p y)_{2}(2,5-\right.$ tpy)][PF 6 . This complex emits orange-red light both in solution (PL $\lambda_{\mathrm{em}}{ }^{\max }=604$ $\mathrm{nm})$ and in a LEC (PL $\left.\lambda_{\mathrm{em}}{ }^{\mathrm{max}}=611 \mathrm{~nm}\right)$. A LEC in configuration ITO/PEDOT:PSS/Ir-iTMC/Al (see Section 5.1 for the use of LiF) and operated under a constant current of $1.5 \mathrm{~A}$ (current density $=0.5 \mathrm{~mA} \mathrm{~mm}^{-2}$ ) had a fast response, reaching $L_{\max }$ of $324 \mathrm{~cd} \mathrm{~m}^{-2}$ in $11 \mathrm{~min}$. The LEC lifetime was of the order of hours (reported as $250 \mathrm{~min})$ [123]. In the case of [Ir(ppy) $\left.)_{2}(2,5-\mathrm{tpy})\right]^{+}$, 
the non-coordinated pyridyl functionality acts as a bulky, peripheral group and cannot engage in an intra-cation $\pi$-stacking interaction as in $\left[\operatorname{Ir}(\mathrm{ppy})_{2}(\mathrm{tpy})\right]^{+}$.

The narrowing of the HOMO-LUMO gap required to obtain a red-emitting $\left[\operatorname{Ir}\left(\mathrm{C}^{\wedge} \mathrm{N}\right)_{2}\left(\mathrm{~N}^{\wedge} \mathrm{N}\right)\right]^{+}$complex can be realized by attaching electron-donating groups to the $\mathrm{C}^{\wedge} \mathrm{N}$ ligands (see below) or electron-withdrawing groups to the $\mathrm{N}^{\wedge} \mathrm{N}$ ligand. An example of the latter approach is seen in $\left[\operatorname{Ir}(\text { tolpy })_{2}\left(4,4^{\prime}-\right.\right.$ $\left.\left.\left(\mathrm{EtO}_{2} \mathrm{C}\right)_{2} \mathrm{bpy}\right)\right]\left[\mathrm{PF}_{6}\right]\left(\right.$ Htolpy = 2-(4-tolyl)pyridine). In solution, $\left[\operatorname{Ir}(\text { tolpy })_{2}\left(4,4{ }^{\prime}-\right.\right.$ $\left.\left.\left(\mathrm{EtO}_{2} \mathrm{C}\right)_{2} \mathrm{bpy}\right)\right]\left[\mathrm{PF}_{6}\right]$ has a PL $\lambda_{\mathrm{em}}{ }^{\max }=687 \mathrm{~nm}$. Scheme 20 illustrates the incorporation of the same electroluminophore into a polymer. A comparison of the performances of a LEC containing $\left[\operatorname{Ir}(\text { tolpy })_{2}\left(4,4-\left(\mathrm{EtO}_{2} \mathrm{C}\right)_{2} \mathrm{bpy}\right)\right]\left[\mathrm{PF}_{6}\right]$ in the active layer and a polymer light-emitting electrochemical cell (PLEC) showed that both are red-emitting ( 630 and $660 \mathrm{~nm}$, respectively). Both the LEC and PLEC were in configuration ITO/PEDOT:PSS/Ir-iTMC:[BMIM][PF6] (2:1)/Al and driven under a constant bias of $3 \mathrm{~V}$. The most notable feature of this investigation is the enhanced stability shown by the PLEC $\left(t_{1 / 2}=37 \mathrm{~h}\right)$ with respect to the LEC $\left(t_{1 / 2}=0.52 \mathrm{~h}\right)$. This strategy for prolonging device lifetime is, however, at the expense of the turn-on time. The LEC had a faster $t_{\mathrm{on}}$ than the PLEC $\left(0.17 \mathrm{~h} v s .5 .7 \mathrm{~h}\right.$ to reach $L_{\max }$ of $\left.30-40 \mathrm{~cd} \mathrm{~m}^{-2}\right)$, consistent with the lower mobility of the $\left[\mathrm{PF}_{6}\right]^{-}$counter-ions in the PLEC [124].
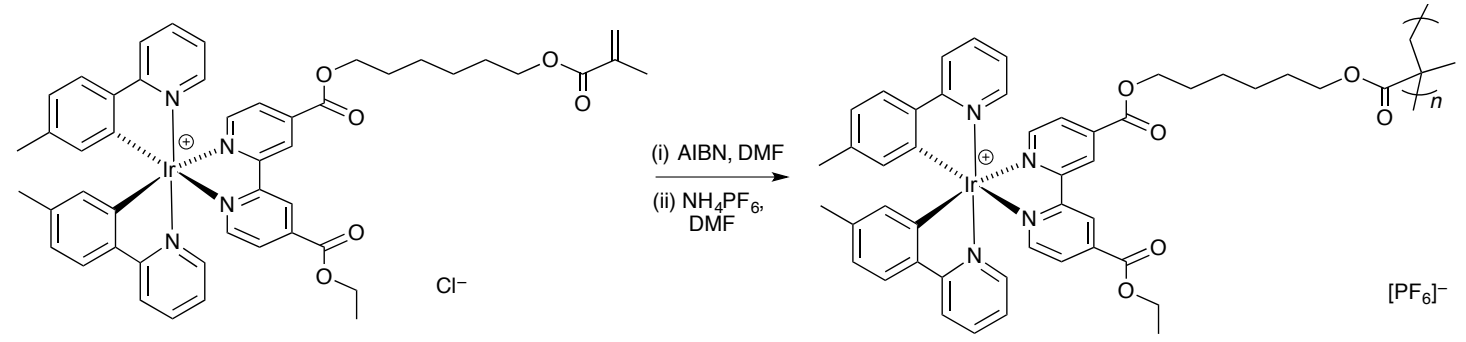

Scheme 20. Synthesis of the red-emitting Ir-iTMC-functionalized polymer (AIBN = azobisisobutyronitrile). 
In Section 6, we overviewed the popular strategy of introducing fluoro or other electron-withdrawing groups into the $\mathrm{C}^{\wedge} \mathrm{N}$ domain to blue-shift the emission of an Ir-iTMC. Despite the widespread use of the latter, the complementary strategy of attaching electron-donating groups to the $\mathrm{C}^{\wedge} \mathrm{N}$ ligands to red-shift the emission has been little explored. Bolink and ZysmanColman [125] reported the series of complexes shown in Scheme 21, demonstrating both regioisomeric effects ([3-MeOpmpy $]^{-}$versus [4-MeOpmpy $\left.]^{-}\right)$ and the effects of introducing one, two or three methoxy substituents into the $\mathrm{C}^{\wedge} \mathrm{N}$ domain. Solution PL maxima range from $618 \mathrm{~nm}$ for $[\operatorname{Ir}(4-$

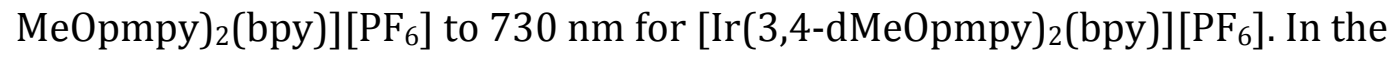
monosubstituted $\mathrm{C}^{\wedge} \mathrm{N}$ ligand, moving the $\mathrm{MeO}$ group from the 3- to 4-position leads to higher PLQY and longer phosphorescence lifetime. Although the

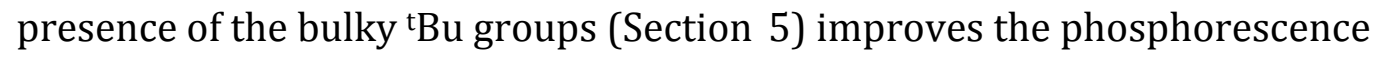
lifetime, non-radiative decay remains dominant. LECs in configuration ITO/PEDOT:PSS/Ir-iTMC:[BMIM][PF6] (4:1)/Al and operated at a constant voltage of $4 \mathrm{~V}$ performed poorly with short device lifetimes. The longest-lived LEC contained $\left[\operatorname{Ir}(3,4,5-\mathrm{tMeOpmpy})_{2}(\mathrm{bpy})\right]\left[\mathrm{PF}_{6}\right]$ in the emissive layer $\left(t_{1 / 2}=16\right.$ h) but this was also the slowest to turn-on ( $8 \mathrm{~h}$ to reach $L_{\max }=21 \mathrm{~cd} \mathrm{~m}^{-2}$ ). In contrast, the LEC with $\left[\operatorname{Ir}\left(4-\mathrm{MeOpmpy}_{2}(\mathrm{bpy})\right]\left[\mathrm{PF}_{6}\right]\right.$ showed a turn-on time (to $\left.L_{\max }\right)$ of only $3 \mathrm{~s}$ and was the brightest of the LECs $\left(L_{\max }=53.1 \mathrm{~cd} \mathrm{~m}^{-2}\right)$; however, it was unstable with $t_{1 / 2}=30 \mathrm{~s}$. The best device contained $[\operatorname{Ir}(3,4,5-$ tMeOpmpy $)_{2}\left(4,4^{\prime}-{ }^{-} \mathrm{Bu}_{2}\right.$ bpy $\left.)\right]\left[\mathrm{PF}_{6}\right]$ and showed $\mathrm{EL} \lambda_{\mathrm{em}}{ }^{\max }=650 \mathrm{~nm}$ compared to the PL $\lambda_{\mathrm{em}}{ }^{\max }=685 \mathrm{~nm}$. It achieved a low maximum luminance of $18 \mathrm{~cd} \mathrm{~m}^{-2}$ in 1.1 $\mathrm{h}$, and had a value of $t_{1 / 2}=2 \mathrm{~h}$. The authors concluded that, although the strategy 
of using electron-donating methoxy groups in the $\mathrm{C}^{\wedge} \mathrm{N}$ ligands leads to deep-red emissions, it does not represent a good design approach for stable red-emitting LECs [125].
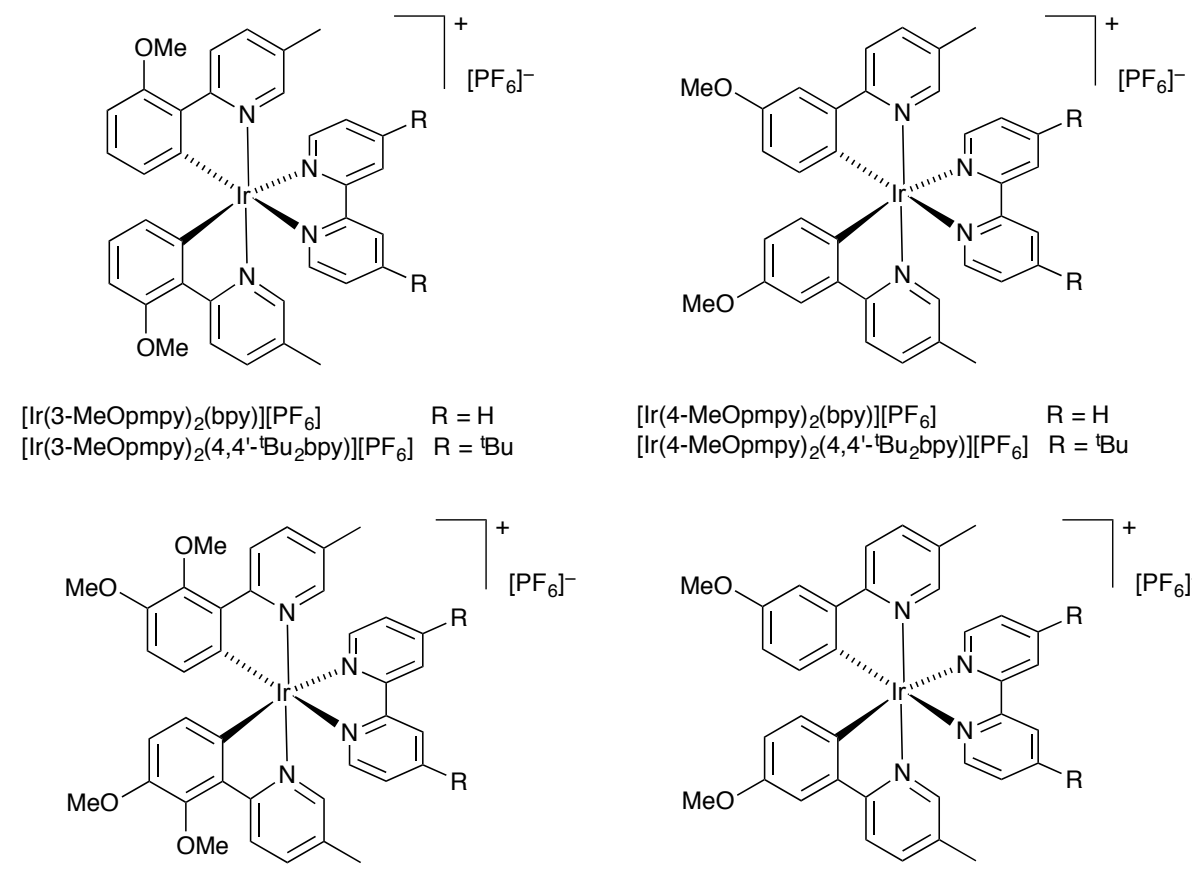

$$
\begin{array}{ll}
{\left[\operatorname{lr}(3,4-d M e O p m p y)_{2}(\text { bpy })\right]\left[P_{6}\right]} & R=H \\
{\left[\operatorname{lr}(3,4-d M e O p m p y)_{2}\left(4,4^{\prime}-\mathrm{Bu}_{2} \text { bpy }\right)\right]\left[\mathrm{PF}_{6}\right]} & \mathrm{R}=\mathrm{t} \mathrm{Bu}
\end{array}
$$$$
\left[\operatorname{lr}(4-\mathrm{MeOpmpy})_{2}(\mathrm{bpy})\right]\left[\mathrm{PF}_{6}\right] \quad \mathrm{R}=\mathrm{H}
$$$$
\left[\operatorname{lr}(4-\mathrm{MeOpmpy})_{2}\left(4,4{ }^{\prime}-\mathrm{Bu}_{2} \mathrm{bpy}\right)\right]\left[\mathrm{PF}_{6}\right] \quad \mathrm{R}=\mathrm{t} \mathrm{Bu}
$$

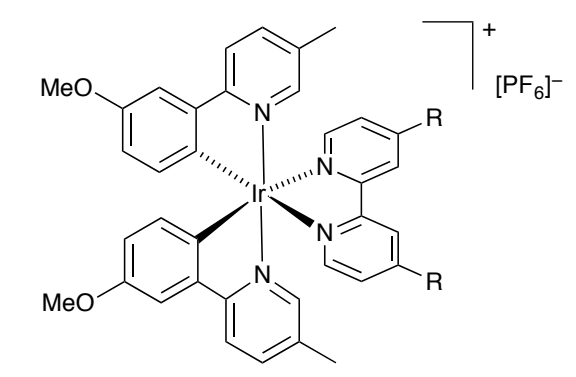

$$
\begin{array}{ll}
{\left[\operatorname{lr}(3,4,5-\mathrm{tMeOpmpy})_{2}(\mathrm{bpy})\right]\left[\mathrm{PF}_{6}\right]} & \mathrm{R}=\mathrm{H} \\
{\left[\operatorname{Ir}(3,4,5-\mathrm{tMeOpmpy})_{2}\left(4,4^{\prime}-\mathrm{BBu}_{2} \mathrm{bpy}\right)\right]\left[\mathrm{PF}_{6}\right]} & \mathrm{R}=\mathrm{tBu}
\end{array}
$$

Scheme 21. Ir-iTMCs incorporating electron-donating groups to the $\mathrm{C}^{\wedge} \mathrm{N}$ ligands.

\section{Conclusions}

As an alternative to OLEDs, LECs offer a simpler device architecture incorporating air stable electrodes such as $\mathrm{Al}$ ). A clear advantage of LECs over OLEDs is that they can be solution (rather than vacuum) processed. White-light emitting devices are a primary target for commercial applications, but are difficult to achieve using a single emissive component. Thus, a common strategy is through the use of blends of two or more emitters; the search for dual-emitting 
single compnent Ir-iTMCs has not, so far, successfully achieved white-light emitting LECs. However, since the HOMO and LUMO of an $\left[\operatorname{Ir}\left(\mathrm{C}^{\wedge} \mathrm{N}\right)_{2}\left(\mathrm{~N}^{\wedge} \mathrm{N}\right)\right]^{+}$ complex are, respectively, localized on the $\operatorname{Ir} / \mathrm{C}^{\wedge} \mathrm{N}$ or $\mathrm{N}^{\wedge} \mathrm{N}$ domains, colourtuning of the emission is readily accomplished by functionalizing the $\mathrm{C}^{\wedge} \mathrm{N}$ and/or $\mathrm{N}^{\wedge} \mathrm{N}$ units thereby altering their electronic properties. The archetype Ir-iTMCs $\left[\operatorname{Ir}(\mathrm{ppy})_{2}(\mathrm{bpy})\right]\left[\mathrm{PF}_{6}\right]$ and $\left[\operatorname{Ir}(\mathrm{ppy})_{2}(\mathrm{phen})\right]\left[\mathrm{PF}_{6}\right]$ are both orange emitters, and they form the structural basis for a very large number of orange-emitting IriTMCs and LECs. For overall white emission, bright and stable blue-emitters are needed to complement these orange-emitters. We have described the different approaches used to widen the HOMO-LUMO gap, thereby increasing the emission energy. While introduction of electron-withdrawing fluoro-groups into the $\mathrm{C}^{\wedge} \mathrm{N}$ domain is a popular choice, it does not necessarily lead to blue-emitting LECs that are stable over time. This instability has led to other strategies for blueemitting electroluminophores. It is the norm to screen the PL characteristics of new Ir-iTMCs before testing them in device configuration. Unfortunately, achieving blue solution PL by careful ligand-design is not a prerequisite for blue EL since a red-shift on going from PL to EL is often observed for wide-bandgap electroluminophores. There remains a need for bright and stable deep-blue IriTMCs and also for stable deep-red emitters. The latter area in particular is ripe for development.

Ligand design plays a crucial role in stabilizing the electroluminophore in its excited state, thereby increasing LEC lifetimes. A successful approach has been the introduction of intra-cation $\pi$-stacking interactions which protect the iridium metal centre in the excited state. However, $\pi$-stacking of rings within the coordination sphere of the iridium centre does not always lead to enhanced 
stability and the involvement of the cyclometallated ring(s) may be an important feature.

While the choice of $\left[\mathrm{PF}_{6}\right]^{-}$as a counter-ion in cyclometallated iridium(III) complexes is common, the relatively large ion size leads to low ion mobility, and this in turn results in slow LEC turn-on times $\left(t_{\mathrm{on}}\right)$. A mean of overcoming this is the use of a pulsed current driving mode for LECs; this also stabilizes the doped regions in the LEC leading to longer lifetimes.

In reviewing the LEC literature, we note that the use of different LEC configurations (e.g. with or without a hole-transport layer, with or without ionic liquid, different ratios of Ir-iTMC:IL) and the use of different LEC operating conditions (e.g. constant voltage, constant current, pulsed voltage, or pulsed current modes) make direct comparisons of device performances difficult. With so many variable parameters, there remains a need for more systematic investigations both of given Ir-iTMCs in LECs of variable configurations and operated under different conditions. Nonetheless, we conclude that over the last few years, significant progress has been made in establishing iridium-based LECs as competitors to iridium-based OLEDs. Key issues for the future are to achieve LECs that combine fast turn-on, enhanced luminance and long life times.

\section{Acknowledgements}

We acknowledge the Swiss National Science Foundation (current grant number 200020_162631), the European Union (CELLO), the European Research Council (Advanced Grant 267816 LiLo), the Swiss Nanoscience Institute and the University of Basel for generous financial support. Our own contributions to the area of LECs would not have been possible without the dedicated work of our 
reseach group and collaborators (especially the groups of Dr Henk Bolink and Professor Enrique Ortí). Structural figures have been drawn using data from the Cambridge Structural Database (CSD) using Conquest v 1.8 [126] and Mercury v. $3.6[126,127]$; structure reference codes (refcodes) are cited in figure captions.

\section{References}

1. Q. Pei, G. Yu, C. Zhang, Y. Yang, A. J. Heeger, Science 269 (1995) 1086.

2. K.M. Maness, R.H. Terrill, T.J. Meyer, R.W. Murray, R.M. Wightman, J. Am. Chem. Soc. 118 (1996) 10609.

3. R.D. Costa, E. Ortí, H.J. Bolink, Pure Appl. Chem. 83 (2011) 2115.

4. J.D. Slinker, J. Rivnay, J.S. Moskowitz, J.B. Parker, S. Bernhard, H.D. Abruña, G.G. Malliaras, J. Mater. Chem. 17 (2007) 2976.

5. M.S. Lowry, S. Bernhard, Chem. Eur. J. 12 (2006) 7970.

6. E. Holder, B.M.W. Langeveld, U.S. Schubert, Adv. Mater. 17, 1109 (2005).

7. C. Ulbricht, B. Beyer, C.A. Friebe, A. Winter, U.S. Schubert, Adv. Mater. 21 (2009) 4418.

8. L. Hu, G. Xu, Chem. Soc. Rev. 39 (2010) 3275.

9. T. Hu, L. He, L. Duan, Y. Qiu, J. Mater. Chem. 22 (2012) 4206.

10. R.D. Costa, E. Ortí, H.J. Bolink, F. Monti, G. Accorsi, N. Armaroli, Angew. Chem. Int. Ed. 51 (2012) 8178.

11. K.P.S. Zanoni, R.L. Coppo, R.C. Amaral, N.Y. M. Iha, Dalton Trans. 44 (2015) 14559.

12. L. Zhou, S. Liu, Q. Zhao, Q. Ling, W. Huang, Prog. Chem. 23 (2011) 1871. 
13. S.B. Meier, D. Tordera, A. Pertegás, C. Roldán-Carmona, E. Ortí, H.J. Bolink, Mater. Today 17 (2014) 217.

14. S. Tang, L. Edman, Topics Curr. Chem. 374 (2016) 40.

15. E. Fresta, R.D. Costa, J. Mater. Chem. C, 2017 DOI: 10.1039/c7tc00202e.

16. D. Ma, C. Zhang, Y. Qiu, L. Duan, J. Mater. Chem. C 4 (2016) 5731.

17. S. Van Reenen, P. Matyba, A. Dzwilewski, R. A. J. Janssen, L. Edman, M.

Kemerink, J. Am. Chem. Soc. 132 (2010) 13776.

18. S.T. Parker, J.D. Slinker, M.S. Lowry, M.P. Cox, S. Bernhard, G.G. Malliaras, Chem. Mater. 17 (2005) 3187.

19. J.D. Slinker, C.Y. Koh, G.G. Malliaras, M.S. Lowry, S. Bernhard, Appl. Phys. Lett. 86 (2005) article 173506.

20. A. Bünzli, A. Pertegás, C. Momblona, J.M. Junquera-Hernández, E.C. Constable, H.J. Bolink, E. Ortí, C.E. Housecroft, Dalton Trans. 45 (2016) 16379.

21. F. De Angelis, F. Santoro, M.K. Nazeruddin, V. Barone, J. Phys. Chem. B 112 (2008) 13181.

22. H.W. Ham, Y.S. Kim, Mol. Cryst. Liquid Cryst. 520 (2010) 384.

23. T. Li, M. Cui, G. Ran, Q. Song, Dyes Pigments 112 (2015) 1.

24. X. Qu, Y. Liu, G. Godefroid, Y. Si, X. Shang, X. Wu, Z. Wu, Eur. J. Inorg. Chem. (2013) 3370.

25. X. Qu, Y. Liu, Y. Si, X. Wu, Z. Wu, Dalton Trans. 43 (2014) 1246.

26. K.P.S. Zanoni, B.K. Kariyazaki, A.A. Ito, M.K. Brennaman, T.J. Meyer, N.Y.M. Iha, Inorg. Chem. 53 (2014) 4089.

27. S. Sprouse, K. A. King, P.J. Spellane, R.J. Watts, J. Am. Chem. Soc. 106 (1984) 6647. 
28. C.D. Ertl, J. Cerda, J.M. Junquera-Hernández, A. Pertegás, H.J. Bolink, E.C.

Constable, M. Neuburger, E. Ortí, C.E. Housecroft, RSC Adv. 5 (2015) 42815.

29. E. Baranoff, B.F.E. Curchod, J. Frey, R. Scopelliti, F. Kessler,I. Tavernelli, U.

Rothlisberger, M. Grätzel, M.K. Nazeeruddin, Inorg. Chem. 51 (2012) 215.

30. D. Tordera, M. Delgado, E. Ortí, H.J. Bolink, J. Frey, M.K. Nazeeruddin, E.

Baranoff, Chem. Mater. 24 (2012) 1896.

31 D. Ma, L. Duan, Y. Qiu, Dalton Trans. 44 (2015) 8521.

32. C.D. Sunesh, M. Chandran, S. Ok, Y. Choe, Mol. Cryst. Liq. Cryst. 584 (2013) 131.

33. M. Lepeltier, B. Graff, J. Lalevée, G. Wantz, M. Ibrahim-Ouali, D. Gigmes, F. Dumur, Org. Electron. 37 (2016) 24.

34. G.E. Schneider, H.J. Bolink, E.C. Constable, C.D. Ertl, C.E. Housecroft, A.

Pertegás, J.A. Zampese, A. Kanitz, F. Kessler, S. B. Meier, Dalton Trans. 43 (2014) 1961.

35. B. Schmid, F. O. Garces, R. J. Watts, Inorg. Chem. 33 (1994) 9.

36. A.M. Bünzli, E.C. Constable, C.E. Housecroft, A. Prescimone, J.A. Zampese, G. Longo, L. Gil-Escrig, A. Pertegás, E. Ortí, H.J. Bolink, Chem. Sci. 6 (2015) 2843. 37 C.D. Ertl, C. Momblona, A. Pertegás, J.M. Junquera-Hernández, M.G. La-Placa, A. Prescimone, E. Ortí, C.E. Housecroft, E.C. Constable, H.J. Bolink, J. Am. Chem. Soc., 139 (2017) 3237.

38. F. Monti, A. Baschieri, I. Gualandi, J.J. Serrano-Perez, J.M. Junquera-Hernández, D. Tonelli, A. Mazzanti, S. Muzzioli, S. Stagni, C. Roldan-Carmona, A. Pertegás, H.J. Bolink, E. Ortí, L. Sambri, N. Armaroli, Inorg. Chem. 53 (2014) 7709. 
39. C.-H. Yang, J. Beltran, V. Lemaur, J. Cornil, D. Hartmann, W. Sarfert, R.A.

Fröhlich, C. Bizzarri, L. De Cola, Inorg. Chem. 49 (2010) 9891.

40. R.D. Costa, E. Ortí, H.J. Bolink, S. Graber, S. Schaffner, M. Neuburger, C.E.

Housecroft, E.C. Constable, Adv. Funct. Mater. 19 (2009) 3456.

41. R.D. Costa, F. Monti, G. Accorsi, A. Barbieri, H.J. Bolink, E. Ortí, N. Armaroli, Inorg. Chem. 50 (2011) 7229.

42. Y. Shen, D.D. Kuddes, C.A. Naquin, T.W. Hesterberg, C. Kusmierz, B.J. Holliday, J.D. Slinker, Appl. Phys. Lett. 102 (2013) article 203305.

43. K.J. Suhr, L.D. Bastatas, Y. Shen, L. A. Mitchell, B.J. Holliday, J.D. Slinker, ACS Appl. Mater. Interfaces 8 (2016) 8888.

44. C. Janiak, Dalton Trans. (2000) 3885.

45. S. Graber, K. Doyle, M. Neuburger, C.E. Housecroft, E.C. Constable, R.D. Costa, E. Ortí, D. Repetto, H.J. Bolink, J. Am. Chem. Soc. 130 (2008) 14944.

46. H.J. Bolink, E. Coronado, R.D. Costa, E. Ortí, M. Sessolo, S. Graber, K.A. Doyle, M. Neuburger, C.E. Housecroft, E.C. Constable, Adv. Mater. 20 (2008) 3910.

47. R.D. Costa, E. Ortí, H.J. Bolink, S. Graber, C.E. Housecroft, E.C. Constable, Chem. Commun. 47 (2011) 3207.

48. R.D. Costa, E. Ortí, H.J. Bolink, S. Graber, C.E. Housecroft, M. Neuburger, S.

Schaffner, E.C. Constable, Chem. Commun. (2009) 2029.

49. G.E. Schneider, A. Pertegás, E.C. Constable, C.E. Housecroft, N. Hostettler, C.D. Morris, J.A. Zampese, H.J. Bolink, J.M. Junquera-Hernández, E. Ortí, M. Sessolo, J. Mater. Chem. C 2 (2014) 7047.

50. P. Li, G.-G. Shan, H.-T. Cao, D.-X. Zhu, Z.-M. Su, R. Jitchati, M.R. Bryce, Eur. J. Inorg. Chem. (2014) 2376. 
51. R.D. Costa, E. Ortí, H.J. Bolink, S. Graber, C.E. Housecroft, E.C. Constable, Adv. Funct. Mater. 20 (2010) 1511.

52. R.D. Costa, E. Ortí, H.J. Bolink, S. Graber, C.E. Housecroft, E.C. Constable, J. Am. Chem. Soc. 132 (2010) 5978.

53. L. He, L. Duan, J. Qiao, D. Zhang, L. Wang, Y. Qiu, Chem. Commun. 47 (2011) 6467.

54. H.-F. Chen, W.-Y. Hung, S.-W. Chen, T.-C. Wang, S.-W. Lin, S.-H. Chou, C.-T. Liao, H.-C. Su, H.-A. Pan, P.-T. Chou, Y.-H. Liu, K.-T. Wong, Inorg. Chem. 51 (2012) 12114

55. E.C. Constable, C.E. Housecroft, G.E. Schneider, J.A. Zampese, H.J. Bolink, A. Pertegás, C. Roldan-Carmona, Dalton Trans. 43 (2014) 4653.

56. R.D. Costa, R. Casillas, J. Cano, J. Phys. Chem. C 117 (2013) 8545.

57. R.D. Costa, E. Ortí, D. Tordera, A. Pertegás, H.J. Bolink, S. Graber, C.E.

Housecroft, L. Sachno, M. Neuburger, E.C. Constable, Adv. Energy Mater. 1 (2011) 282.

58. L. Sun, A. Galan, S. Ladouceur, J. D. Slinker, E. Zysman-Colman, J. Mater. Chem. $21(2011) 18083$.

59. K.J. Suhr, L.D. Bastatas, Y. Shen, L.A. Mitchell, G.A. Frazier, D.W. Taylor, J.D.

Slinker, B.J. Holliday, Dalton Trans. 45 (2016) 17807.

60. Y. Shen, D. D. Kuddes, C. A. Naquin, T. W. Hesterberg, C. Kusmierz, B. J.

Holliday, J. D. Slinker, Appl. Phys. Lett. 102 (2013) 203305.

61. H.J. Bolink, L. Cappelli, E. Coronado, M. Grätzel, E. Ortí, R.D. Costa, P.M.A. Viruela, Md.K. Nazeeruddin, J. Am. Chem. Soc. 128 (2006) 14786.

62. J. Wang, S. Xu, F. Zhao, H. Xia, Y. Wang, J. Mol. Struct. 1108 (2016) 46. 
63. D. Tordera, A. Pertegás, N.M.A. Shavaleev, R. Scopelliti, E. Ortí, H.J. Bolink, E. Baranoff, M. Grätzel, M.K. Nazeeruddin, J. Mater. Chem. 22 (2012) 19264.

64. D.R. Martir, C. Momblona, A. Pertegás, D.B. Cordes, A.M.Z. Slawin, H.J. Bolink, E. Zysman-Colman, ACS Appl. Mater. Interfaces 8 (2016) 33907.

65. D. Tordera, S. Meier, M. Lenes, R.D. Costa, E. Ortí, W. Sarfert, H.J. Bolink, Adv. Mater. 24 (2012) 897.

66. N.M. Shavaleev, R. Scopelliti, M. Grätzel, M.K. Nazeeruddin, A. Pertegás, C. Roldan-Carmona, D. Tordera, H.J. Bolink, J. Mater. Chem. C 1, 2241 (2013).

67. A.M. Bünzli, H.J. Bolink, E.C. Constable, C.E. Housecroft, M. Neuburger, E. Ortí, A. Pertegás, J.A. Zampese, Eur. J. Inorg. Chem. (2012) 3780.

68. F. Brunner, L. Martínez-Sarti, S. Keller, A. Pertegás, A. Prescimone, E.C. Constable, H.J. Bolink, C.E. Housecroft, Dalton Trans. 45 (2016) 15180.

69. H.J. Bolink, L. Cappelli, S. Cheylan, E. Coronado, R.D. Costa, N. Lardiés, M.K. Nazeeruddin, E. Ortí, J. Mater. Chem. 17, (2007) 5032.

70. R.D. Costa, P.M. Viruela, H.J. Bolink, E. Ortí, J. Mol. Struct. THEOCHEM 912 (2009) 21.

71. Y. Kwon, C.D. Sunesh, Y. Choe, Opt. Mater. 39 (2015) 40.

72. D. Tordera, J.J. Serrano-Pérez, A. Pertegás, E. Ortí, H.J. Bolink, E. Baranoff, Md.K. Nazeeruddin, J. Frey, Chem. Mater. 25, 3391 (2013).

73. V. Sivasubramaniam, F. Brodkorb, S. Hanning, H.P. Loebl, V. van Elsbergen, H. Boerner, U. Scherf, M. Kreyenschmidt, J. Fluorine Chem. 130 (2009) 640.

74. I.R. de Moraes, S. Scholz, B. Lüssem, K. Leo, Org. Electronics 12 (2011) 341. 
75. N.M. Shavaleev, G. Xie, S. Varghese, D.B. Cordes, A.M.Z. Slawin, C. Momblona,

E. Ortí, H.J. Bolink, I.D.W. Samuel, E. Zysman-Colman, Inorg. Chem. 54 (2015) 5907.

76. N.M. Shavaleev, R. Scopelliti, M. Grätzel, M.K. Nazeeruddin, A. Pertegás, C.

Roldan-Carmona, D. Tordera, H.J. Bolink, J. Mater. Chem. C 1 (2013) 2241.

77. A.K. Pal, D.B. Cordes, A.M.Z. Slawin, C. Momblana, E. Ortí, I.D.W. Samuel, H.J.

Bolink, E. Zysman-Colman, Inorg. Chem. 55 (2016) 10361.

78. D. Tordera, A.M. Bünzli, A. Pertegás, J.M. Junquera-Hernández, E.C. Constable,

J.A. Zampese, C.E. Housecroft, E. Ortí, H.J. Bolink, Chem. Eur. J. 19 (2013) 8597.

79. E.C. Constable, C.D. Ertl, C.E. Housecroft, J.A. Zampese, Dalton Trans. 43 (2014) 5343.

80. C.D. Ertl, L. Gil-Escrig, J. Cerdá, A. Pertegás, H.J. Bolink, J.M. Junquera-

Hernández, A. Prescimone, M. Neuburger, E.C. Constable, E. Ortí, C.E. Housecroft, Dalton Trans. 45 (2016) 11668.

81. S. Evariste, M. Sandroni, T.W. Rees, C. Roldan-Carmona, L. Gil-Escrig, H.J.

Bolink, E. Baranoff, E. Zysman-Colman, J. Mater. Chem. C 2 (2014) 5793.

82. A.B. Tamayo, B.D. Alleyne, P.I. Djurovich, S. Lamansky, I. Tsyba, N.N. Ho, R. Bau, M.E. Thompson, J. Am. Chem. Soc. 125 (2003) 7377.

83. A.B. Tamayo, S. Garon, T. Sajoto, P.I. Djurovich, I.M. Tsyba, R. Bau, M.E. Thompson, Inorg. Chem. 44 (2005) 8723.

84. M. Maestri, D. Sandrini, V. Balzani, U. Maeder, A. von Zelewsky, Inorg. Chem. 26 (1987) 1323.

85. C.D. Sunesh, M. Chandran, G. Mathai, Y. Choe, Opt. Mater. 35 (2013) 407.

86. C.D. Sunesh, S. Ok, G. Mathai, Y. Choe, Thin Solid Films 531 (2013) 530. 
87. C.D. Sunesh, G. Mathai, Y.-R. Cho, Y. Choe, Polyhedron 57 (2013) 77.

88. See for example: K. Dedeian, J. Shi, N. Shepherd, E. Forsythe, D.C. Morton, Inorg. Chem. 44 (2005) 4445.

89. E. Baranoff, H.J. Bolink, E.C. Constable, M. Delgado, D. Häussinger, C.E.

Housecroft, Md.K. Nazeeruddin, M. Neuburger, E. Ortí, G.E. Schneider, D. Tordera, R.M. Walliser, J.A. Zampese, Dalton Trans. 42 (2013) 1073.

90. E. Baranoff, S. Fantacci, F. De Angelis, X. Zhang, R. Scopelliti, M. Grätzel, Md.K. Nazeeruddin, Inorg. Chem. 50 (2011) 451.

91. T. Karatsu, M. Takahashi, S. Yagai, A. Kitamura, Inorg. Chem. 52 (2013) 12338.

92. K.P. Klubek, S.-C. Dong, L.-S. Liao, C.W. Tang, L.J. Rithberg, Org. Electronics 15 (2014) 3127.

93. L. He, Z. Wang, C. Yang, L. Duan, R. Tang, X. Song, C. Pan, Dyes Pigments 131 (2016) 76.

94. M. Felici, P. Contreras-Carballada, J.M.M. Smits, R.J.M. Nolte, R.M. Williams, L. De Cola, M.C. Feiters, Molecules 15 (2010) 2039.

95. T.U. Connell, J.M. White, T.A. Smith, P.S. Donnelly, Inorg. Chem. 55 (2016) 2776.

96. S. Ladouceur, D. Fortin, E. Zysman-Colman, Inorg. Chem. 50 (2011) 11514.

97. L. Donato, P. Abel, E. Zysman-Colman, Dalton Trans. 42 (2013) 8402.

98. J.M. Fernández-Hernández, C.-H. Yang, J.I. Beltrán, V. Lemaur, F. Polo, R. Fröhlich, J. Cornil, L. De Cola, J. Am. Chem. Soc. 133 (2011) 10543. 
99. J.M. Fernández-Hernández, J.I. Beltrán, V. Lemaur, M.-D. Gálvez-López, C.-H. Chien, F. Polo, E. Orselli, R. Fröhlich, J. Cornil, L. De Cola, Inorg. Chem. 52 (2013) 1812.

100. M.K. Nazeeruddin, R.T. Wegh, Z. Zhou, C. Klein, Wang, Q., F. De Angelis, S. Fantacci, M. Grätzel, Inorg. Chem. 45 (2006) 9245.

101. L. He, L. Duan, J. Qiao, R. Wang, P.A. Wei, L. Wang, Y. Qiu, Adv. Funct. Mater. $18(2008) 2123$.

102. T. Hu, L. Duan, J. Qiao, L. He, D. Zhang, R. Wang, L. Wang, Y. Qiu, Org. Electron. 13 (2012) 1948.

103. C.D. Sunesh, M.S. Subeesh, K. Shanmugasundaram, R.K. Chitumalla, J. Jang, Y. Choe, Dyes Pigments, 128 (2016) 190.

104. C.D. Sunesh, K. Shanmugasundaram, M.S. Subeesh, R.K. Chitumalla, J. Jang, Y. Choe, ACS Appl. Mater. Interfaces 7 (2015) 7741.

105. L. He, D. Ma, L. Dian, Y. Wei, J. Qiao, D. Zhang, G. Dong, L. Wang, Y. Qiu, Inorg. Chem. 51 (2012) 4502.

106. C.D. Sunesh, G. Mathai, Y. Choe, Org. Electronics 15 (2014) 667.

107. J.-H- Jou, S. Kumar, A. Afrawal, T.-H. Li, S. Sahoo, J. Mater. Chem. C 3 (2015) 2974.

108. L. He, J. Qiao, L. Duan, G. Dong, D. Zhang, L. Wang, Y. Qiu, Adv. Funct. Mater. 19 (2009) 2950.

109. C.D. Sunesh, G. Mathai, Y. Choe, ACS Appl. Mater. Interfaces 6 (2014) 17416. 110. M. Mydlak, C. Bizzarri, D. Hartmann, W. Sarfert, G. Schmid, L. De Cola, Adv. Funct. Mater. 20 (2010) 1812. 
111. J.M. Fernández-Hernández, S. Ladouceur, Y. Shen, A. Iordache, X. Wang, L.

Donato, S. Gallagher-Duval, M. de Anda Villa, J.D. Slinker, L. De Cola, E. ZysmanColman, J. Mater. Chem. C 1 (2013) 7440.

112. B. Chen, Y. Li, W. Yang, W. Luo, H. Wu, Org. Electronics 12 (2011) 766.

113. S.B. Meier, W. Sarfert, J.M. Junquera-Hernández, M. Delgado, D. Tordera, E. Ortí, H.J. Bolink, F. Kessler, R. Scopelliti, M. Grätzel, M.K. Nazeeruddin, E. Baranoff, J. Mater. Chem. C 1 (2013) 58.

114. F. Kessler, R.D. Costa, D. Di Censo, R. Scopelliti, E. Ortí, H.J. Bolink, S. Meier, W. Sarfert, M. Grätzel, Md.K. Nazeeruddin, E. Baranoff, Dalton Trans. 41 (2012) 180.

115. F. Zhang, L. Duan, J. Qiao, G. Dong, L. Wang, Y. Qiu, Org. Electronics 13 (2102) 2442.

116. R.D. Costa, R. Casillas, J. Cano, J. Phys. Chem. C 117 (2013) 8545.

117. H.-C. Su, H.-F. Chen, F.-C. Fang, C.-C. Liu, C.-C. Wu, K.-T. Wong, Y.-H. Liu, S.-M. Peng, J. Am. Chem. Soc. 130 (2008) 3413.

118. J.E. Namanga, N. Gerlitzki, B. Mallick, A.-V. Mudring, J. Mater. Chem. C 5 (2017) 3049.

119. T. Hu, L. Duan, J. Qiao, L. He D. Zhang, L. Wang, Y. Qiu, Synth. Metals 163 (2013) 33.

120. J. Zhang, L. Zhou, H. A. Al-Attar, K. Shao, L. Wang, D. Zhu, Z. Su, M.R. Bryce, A.P. Monkman, Adv. Funct. Mater. 23 (2013) 4667.

121. C.D. Ertl, C. Momblona, A. Pertegás, J.M. Junquera-Hernández, M.-G. La-Placa, A. Prescimone, E. Ortí, C.E. Housecroft, E.C. Constable, H.J. Bolink, J. Am. Chem. Soc. 139 (2017) 3237. 
122. D.P. Ris, G.E. Schneider, C.D. Ertl, E. Kohler, T. Müntener, M. Neuburger, E.C.

Constable, C.E. Housecroft, J. Organomet. Chem. 812 (2016) 272.

123. K. Hasan, L. Donato, Y. Shen, J.D. Slinker, E. Zysman-Colman, Dalton Trans., $43(2014) 13672$.

124. J.L. Rodriguez-Redondo, R.D. Costa, E. Ortí, A. Sastre-Santos, H.J. Bolink, F. Fernández-Lázaro, Dalton Trans. (2009) 9787.

125. K. Hasan, A.K. Bansal, I.D.W. Samuel, C. Roldán-Carmona, H.J. Bolink, E. Zysman-Colman, Sci. Rep. 5 (2015) 12325.

126. I.J. Bruno, J.C. Cole, P.R. Edgington, M. Kessler, C.F. Macrae, P. McCabe, J. Pearson, and R. Taylor, Acta Cryst. B 58, 389 (2002).

127. C.F. Macrae, I.J. Bruno, J.A. Chisholm, P.R. Edgington, P. McCabe, E. Pidcock, L. Rodriguez-Monge, R. Taylor, J. van de Streek, and P.A. Wood, J. Appl. Cryst. 41, 466 (2008). 